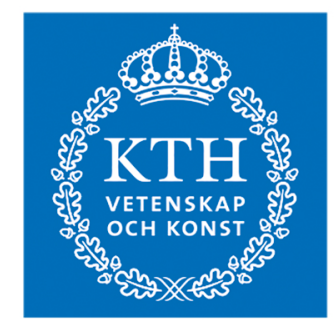

\title{
Steering sustainability transitions? Modular participatory backcasting for strategic planning in the heating and cooling sector
}

KATERYNA PEREVERZA

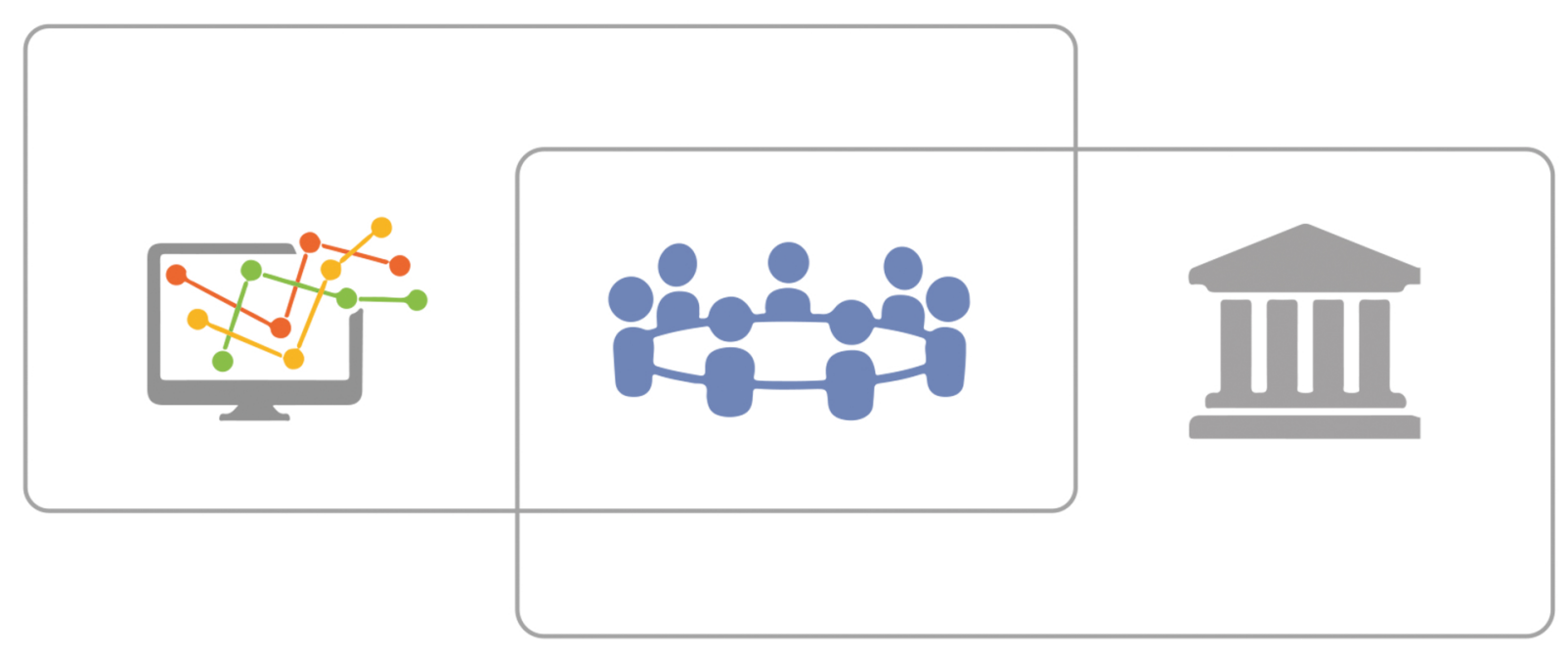




\title{
Steering sustainability transitions? Modular participatory backcasting for strategic planning in the heating and cooling sector
}

\author{
KATERYNA PEREVERZA
}


Academic Dissertation which, with due permission of the KTH Royal Institute of Technology, is submitted for public defence for the Degree of Doctor of Philosophy on

Friday the 12th of April 2019, at 10:15 a.m. in F3, Linsdtedtsvägen 26, Stockholm.

Title: Steering sustainability transitions? Modular participatory backcasting for strategic planning in the heating and cooling sector

Title in Swedish: Styra omställningsprocesser för ökad hållbarhet? Modulär deltagande backcasting för strategisk planering inom värme och kyla

Author: Kateryna Pereverza

KTH Royal Institute of Technology

School of Architecture and the Built Environment

Department of Sustainable Development, Environmental Science and Engineering

Division of Resources, Energy and Infrastructure

Research Group of Urban Analytics and Transitions

TRITA-ABE-DLT-198

ISBN: 978-91-7873-125-1

Printed by US-AB in Stockholm, Sweden 2019 



\section{Acknowledgements}

This study was only possible because of many people and collaborations that inspired, guided and influenced me and my work. Below, I briefly acknowledge those who were directly connected to this research journey and greatly contributed to the outcomes achieved.

First of all, I would like to thank my four supervisors: Olga Kordas, David Lazarevic, Karel Mulder and Maria Malmström. I am grateful to Olga for guiding and inspiring me for already more than 10 years. For me, she is a role model of an engaged researcher able to drive real-life changes. I would like to thank David for his critical perspective and our thoughtful discussions about research and for intelligibly introducing me to new theories and concepts. I am very grateful to Karel, whose immense erudition always inspired me to see beyond a narrow issue or question. I am thankful to Maria for her support, great attention to detail and encouraging me to develop the skills of an independent researcher. I would like to express my gratitude to the internal advance reviewer of my thesis, Per Lundqvist, who provided me with very insightful feedback. I would also like to acknowledge the influence of the late Leo Jansen whom I was privileged to know and be inspired by.

This thesis was part of three projects conducted by great teams in Ukraine, Serbia and Sweden. I would like to thank Eugene Nikiforovich, Volodymyr Voloshchuk, Roman Bobruyko and Valery Oliynik in Ukraine, and Maria Zivković, Dejan Ivezić, Aleksander Madzarević, Dimitri Manić, Nikola Rakić, Goran Bošković, Vladimir Vukašinović and Bojan Gajić in Serbia. Their thoughtful inputs and dedication made the projects in Bila Tserkva and Niš truly enriching experiences and exceptional learning opportunities. I am also grateful to Jordi Segalas and Jaco Quist for their insightful contributions on different stages of these projects. Special gratitude to Eugene Nikiforovich, from whom I've learnt so much about research and effective research environments. I thank Paula Bögel and Paul Upham for a remarkably productive collaboration during the research project with the Swedish regions. I am also very grateful to everyone who participated in these projects and contributed their knowledge and expertise.

I would like to thank the funding bodies that supported my research. I am thankful to the Swedish Institute for granting me a scholarship to start my $\mathrm{PhD}$ studies in Sweden. I also would like to acknowledge the support by EUfunded projects, ERAIHM in Ukraine (EU FP7-INCO-2010-6, Grant agreement no.266587) and SDTrain in Serbia (EU Tempus Programme, Grant agreement no. 2012-3006), as well as funding from STandUP for Energy. 
I am happy to be a part of our ambitious and truly multidisciplinary team in Urban Analytics and Transitions, UrbanT. I am very thankful to Anders, Aram, Hossein, Marco, Oleksii, Olena, Olga, Simona and Sviatlana for bringing together so many ideas and experiences and for creating an exceptionally friendly atmosphere in our research group.

The Division of Industrial Ecology (IE) and later the Department of Sustainable Development, Environmental Sciences and Engineering (SEED) at KTH were important research environments for me as a PhD student. I would like to thank my senior colleagues and fellow PhD students: Aira, Annika, Björn, Cecilia, Daniel, Fredrik, Marcus, Maria, Miguel, Monika and Nils, JB, Jagdeep, Jiechen, Joseph, Mauricio, Rajib and Raphael, Asterios, Elias, Hanna, Kåre and Vincent. My special thanks go to one of the most welcoming persons I've ever met, Karin. I would also like to thank Kosta for his support with various practicalities. I would especially like to thank Aina Bruno and Hanna Eggestrand for being fantastic colleagues in our teaching endeavours.

The International Conference for Sustainability Transitions (IST) and events organised by the Network of Early-Career Researcher in Sustainability Transitions (NEST) were an important external research environment for me. Participation in these communities inspired me to plunge into new research areas and learn to build bridges between own discipline and other fields.

I would like to thank my friends, who are now pursuing their research and professional careers in different places around the world and whom I rarely meet in person. I greatly appreciate their support and encouragement, which I still sense even at a distance.

I am extremely thankful to my dear parents, Volodymyr and Tetiana, and sister Olga for their constant support. Finally, I would like to thank Oleksii, who successfully combines the roles of husband, close colleague and most reliable friend. He is a person with whom I have the most thought-provoking conversations and his support is indispensable to me.

Kateryna Pereverza,

Stockholm, March 2019 


\section{Abstract}

Fostering sustainability transitions in the heating and cooling sector is a necessary and urgent issue. Steering mechanisms can enable coordination of actions by different actors towards common sustainability goals. Previous studies have identified requirements relevant for such steering frameworks, but have not specifically addressed planning in the highly contextual heating and cooling sector. Participatory backcasting (PB) possesses a number of relevant characteristics for use as a planning framework in this sector, but its adaptability and potential impact first need to be addressed.

This thesis sought to advance strategic planning in the heating and cooling sector by improving the adaptability, transparency and reflexivity of PB processes and extending their impact beyond individuals directly involved, so-called social scales of impact. Key research objectives of the present work were to: (1) develop a strategic planning framework for the heating and cooling sector based on PB and examine its adaptability to local contexts, (2) develop methods for scenario development, selection and analysis to allow for co-informing between modelling and participatory processes within PB-based strategic planning, and (3) identify factors that could influence the social scales of the impact of participatory strategic planning processes.

Objectives 1 and 2 were pursued in a multiple case study involving transdisciplinary research over one-year PB-based planning processes in Bila Tserkva, Ukraine (Case I) and Niš, Serbia (Case II). The social scales of impact (Objective 3) were studied in a single case - a Swedish project aimed at advancing the practice of long-term planning in regions 'Region 2050' (Case III). In all cases, both theoretical and empirical research were conducted.

The study proposes a novel framework, modular participatory backcasting (mPB), for strategic planning in the heating and cooling sector. The framework integrates principles of modularity, participatory modelling, and transdisciplinarity. The results of mPB implementation in Case I and Case II suggest that the framework has acceptable adaptability to local contexts. Greater reflexivity and transparency in the scenario development, selection and analysis were achieved by developing a morphological method and implementation of participatory modelling approaches. Finally, boundary spanning individuals, collaborations and institutional plurality were identified in Case III as important factors for broadening the social scales of impact of participatory strategic planning processes. 


\section{Keywords}

Sustainability transitions, strategic planning, participatory backcasting, scenarios, modularity, participatory modelling, transdisciplinarity, organisational changes, heating and cooling sector. 


\section{Sammanfattning}

Det är både angeläget och brådskande att främja hållbara omställningsprocesser för värme och kyla inom energisektorn. Det finns olika styrmekanismer som kan möjliggöra samordning av olika aktörers insatser mot gemensamma hållbarhetsmål inom sektorn. Tidigare studier har identifierat relevanta krav för styrning av ett ramverk för detta, men de har då inte specifikt behandlat styrning inom värme och kyla. Deltagande backcasting (eng. participatory backcasting, PB) har ett antal relevanta egenskaper för att kunna användas som just ett sådant ramverk för planering inom området. Däremot behöver användning av PB i sektorn utvärderas med avseende på lokal anpassningsbarhet och användbarhet.

Den här avhandling syftar till att vidareutveckla strategisk planering för området värme och kyla genom att öka anpassningsbarheten, transparensen och reflixiviteten av PB-processer samt genom att utvidga ramverkets påverkan till ett vidare sammanhang (än de individer som är direkt berörda). De huvudsakliga forskningsmålen var att: (1) utveckla ett strategiskt ramverk för planering för området värme och kyla baserad på PB och att undersöka hur anpassningsbart ramverket är i förhållande till lokala förutsättningar; (2) utforska metoder för utveckling, urval och analys av scenarier som möjliggör informationsöverföring mellan modellering och deltagandeprocesser inom strategisk planering baserad på PB; och (3) identifiera faktorer som kan sprida påverkan bortom de individer som är direkt involverade i deltagandeprocesserna.

Mål 1 och 2 har behandlats i en flerfallstudie som omfattar tvärvetenskaplig forskning över ett års tid, PB-baserade planeringsprocesser i Bila Tserkva, Ukraina (Fall I) och Niš, Serbien (Fall II). De vidare effekterna av deltagandeprocesserna studerades i en fallstudie i Sverige där projektet syftade till att vidareutveckla praktiken för långsiktig planering i regioner, framsynsprocessen "Region 2050" (Fall III). I samtliga fall kombinerades teoretisk och empirisk forskning.

Studien föreslår ett nytt ramverk, modulär deltagande backcasting (mPB), för strategisk planering inom värme och kyla. Ramverket integrerar principer för modularitet, deltagandemodellering och tvärvetenskaplighet. Implementering av modulär deltagande backcasting (mPB) visar godtagbar lokal anpassningsbarhet vid användning i både Fall I och Fall II. Genom utveckling av en morfologisk metod samt införandet av deltagande modelleringsprocesser uppnåddes en högre grad av reflexivitet och ökad transparens i de PB-baserade planeringsprocesserna för scenarioutveckling, 
scenariourval och scenarioanalys. Slutligen identifierades faktorer som gränsgöverskidare (eng. boundary spanning individuals), samarbeten och institutionell mångfald som viktiga för att bredda PB-processens effekter i ett vidare sammanhang.

\section{Nyckelord}

Omställningsprocesser, strategisk planering, deltagande backcasting, modularitet, deltagandemodellering, tvärvetenskap, organisationsförändringar, uppvärmning och kylning. 


\section{Анотація}

Сприяння переходу до сталого розвитку в сфері тепло- та холодозабезпечення населених пунктів $є$ однією з нагальних потреб в енергетиці. Тоді як досягнення цілей сталого розвитку (англ. Sustainable Development Goals) потребує координації та взаємодії різних акторів. Попередні дослідження визначили ключові вимоги, яким мають відповідати координаційні механізми в інфраструктурних секторах. В той же час, такі механізми та зокрема стратегічне планування в сфері тепло- та холодозабезпечення, яка суттєво залежить від умов функціонування, залишаються мало розробленими. Беккастинг із залученням всіх зацікавлених акторів (англ. participatory backcasting, PB) вирізняється низкою характеристик, що роблять його цікавим для вивчення в контексті довгострокового планування в цій сфері.

Дане дослідження присвячене вдосконаленню стратегічного планування в сфері тепло- та холодозабезпечення шляхом підвищення адаптивності, прозорості та рефлексивності процесів на основі РВ. Дослідження передбачає вивчення наступних задач: (1) розроблення підходу до стратегічного планування в сфері тепло- та холодозабезпечення на основі РВ та вивчення його адаптивності до локальних умов, (2) розроблення методів для побудови, вибору та аналізу сценаріїв, які б дозволяли взаємне інформування між моделюванням та процесами планування на основі PB, та (3) визначення факторів, які можуть посилити вплив процесів стратегічного планування на трансформації на рівні організацій та всієї системи.

Вивчення задач (1) i (2) було реалізовано як трансдисциплінарне дослідження двох кейсів - процесів стратегічного планування тривалістю один рік кожен в містах Біла Церква, Україна (Кейс I) та Ніш, Сербія (Кейс II). Дослідження задачі (3) базувалося на проекті “Region 2050", який мав на меті вдосконалення підходів до стратегічного планування в регіонах Швеції (Кейс III).

На основі результатів дослідження, запропоновано новий підхід до стратегічного планування в сфері тепло- та холодозабезпечення модульний беккастинг (англ. modular participatory backcasting, mPB). Цей підхід було розроблено з використанням принципів модулярності, участі різних акторів у моделюванні та принципу трансдисциплінарності. Тестування МРB у двох кейсах (Кейси I та II) продемонструвало прийнятну адаптивність підходу до локальних умов та обмежень проектів. Розроблені методи для побудови та аналізу 
сценаріїв - морфологічний метод та метод моделювання за участі акторів, підвищили прозорість та рефлексивність розробки сценаріїв, а також збільшили кількість розглянутих альтернатив. В рамках Кейсу III було визначено, що (а) роль осіб як посередників між piзними контекстами (англ. boundary spanning individuals), (б) співпраця та (в) інституційний плюралізм $\epsilon$ важливими факторами для посилення впливу процесів стратегічного планування.

\section{Ключові слова}

Перехід до систем сталого розвитку, стратегічне планування, беккастинг, сценарне планування, модулярність, моделювання, залучення зацікавлених акторів, трансдисциплінарність, організаційні зміни, тепло- та холодозабезпечення. 


\section{Rezime}

Podsticanje promena, koje doprinose poboljšanju održivosti sektora grejanja i hlađenja, je neophodan i neodložan zadatak. Različitim mehanizmima upravljanja može se uspostaviti koordinacija akcija različitih aktera u cilju ispunjenja zajedničkog cilja. Prethodne studije i radovi identifikovali su zahteve koje treba da ispune sistemi upravljanja, ali se nisu bavili planiranjem u specifičnom kontekstu sektora grejanja i hlađenja. Participativni bekkasting (engl. participatory backcasting, PB) metoda planiranja bi u toku procesa planiranja uzela u obzir brojne uticajne činioce i karakeristike vezane za ovaj sektor. Međutim, prvo se mora utvdtiti adaptibilnost i potencijalni uticaj primene ove metode.

Ova teza bavi se unapređenjem procesa strateškog planiranja u sektoru grejanja i hlađenja, koji je zasnovan na unapređenju adaptibilnosti, transparentnosti i refleksivnosti PB procesa i širenjem uticaja procesa, sa direknto uključenih pojedinace na širu društvenu zajednicu. Osnovni ciljevi istraživanja bili su: (1) da se razvije strateški okvir za planiranje u sektoru grejanja i hlađenja zasnovan na PB i da se ispita njegova adaptibilnost na lokalne uslove, (2) da se razviju metode za razvoj, selekciju i analizu scenarija sa uspostaviljanjem razmene informacija između modeliranja i participativnog procesa, a koji se sprovode u okviru strateškog planiranja zasnovanog na PB i (3) da se identifikuju faktori koji mogu da imaju širi društveni uticaj indukovan procesom participativnog strateškog planiranja.

Ciljevi 1 i 2 obrađivani su u višestrukoj studiji slučaja koje je uključivalo transdisciplinarno istraživanje. Istraživanje je trajalo duže od godinu dana i obuhvatilo je proces planiranja zasnovan na PB na primeru Bele Crkve, Ukrajina (Slučaj I) i primeru Niša, Srbija (Slučaj II). Nivoi šireg društvenog uticaja (Cilj 3) su istraživani na primeru švedskog projekta koji je imao za cilj unapređenje procesa dugoročnog planiranja u regionima, 'Region 2050' (Slučaj III). U svim analiziranim slučajevima teoretsko istraživanje je kombinovano sa empirijskim podacima.

Sprovedeno istraživanje predlaže novi okvir za strateško planiranje u sektoru grejanja i hlađenja, modularni participativni bekkasting (mPB). Predloženi okvir integriše principe modularnosti, participativnog modeliranja i transdisciplinarnosti. Rezultati ukazuju da mPB ima prihvatljivu adaptibilnost za primenu u Slučaju I i Slučaju II. Veća refleksivnost i transparentnost procesa razvoja scenarija, njihovog izbora i analize postignute su razvojem morfološke metode i primenom principa participativnog modeliranja. Konačno, uloga pojedinaca kao posrednika 
između različitih konteksta (engl. boundary spanning individuals), saradnja i institucionalni pluralizam su identifikovani u okviru Slučaja III kao važni faktori za širenje šireg društvenog uticaja kao rezultat procesa participativnog strateškog planiranja.

\section{Ključne reči}

Tranzicija ka održivosti, strateško planiranje, participativni bekkasting, scenariji, modularnost, participativno modeliranje, transdisciplinarnost, organizacione promene, sektor grejanja i hlađenja. 


\section{List of appended papers}

\section{Paper I}

Pereverza, K., Pasichnyi, O., Kordas, O., 2019. Modular participatory backcasting: A unifying framework for strategic planning in the heating sector. Energy Policy 124, pp. 123-134. https://doi.org/10.1016/j.enpol.2018.09.027

My contribution to this paper was: development of the research idea and research design, data collection and analysis, writing the paper, and handling its submission and publication.

\section{Paper II}

Pereverza, K., Pasichnyi, O., Lazarevic, D., Kordas, O., 2017. Strategic planning for sustainable heating in cities: A morphological method for scenario development and selection. Applied Energy 186(2), pp. 115-125.

http://dx.doi.org/10.1016/j.apenergy.2016.07.008

My contribution to this paper was: development of the research idea and research design, data collection and analysis, writing the paper, and handling its submission and publication.

\section{Paper III}

Zivkovic, M., Pereverza, K., Pasichnyi, O., Madzarevic, A., Ivezic, D., Kordas, O., 2016. Exploring scenarios for more sustainable heating: The case of Niš, Serbia. Energy 115(3), pp. 1758-1770. http://dx.doi.org/10.1016/j.energy.2016.06.034

My contribution to this paper was: development of the research idea and research design, development of the approach for integration of modelling in the participatory process, data collection and analysis, writing sections of the paper and providing comments to the final manuscript.

\section{Paper IV}

Bögel, P.M., Pereverza, K., Upham, P., Kordas, O., 2019. Linking socio-technical transition studies and organizational change management: Steps towards an integrative heuristic. Submitted to the Journal of Cleaner Production.

My contribution to this paper was: development of the research idea and research design, conducting part of the interviews, data analysis, writing sections of the paper and providing comments to the final manuscript. 


\section{Additional publications not included in this thesis}

Pereverza. K., Kordas, O., 2017. Sustainability through stakeholder learning: Participatory backcasting for the heating sector, in Ugliati, S. and Vanoli, L., Proceedings of the 1oth Biennial International Workshop on Advances in Energy Studies: Energy futures, environment and well-being. University of Naples 'Perthenope', Naples.

Kordas, O., Pereverza, K., Pasichnyi, O., Nikiforovich, E., 2015. Developing skills for sustainability change agents with a participatory backcasting teaching toolbox, in Nesbit, S. and Froese, T. M. (eds.), Proceedings of EESD15: The 7th Conference on Engineering Education for Sustainable Development, University of British Columbia, Vancouver, pp. 086-1-086-10.

Mulder, K., Ferrer-Balas, D., Segalàs-Coral, J., Kordas, O., Nikiforovich, E., Pereverza, K., 2014. Motivating Students and Lecturers for Education in Sustainable Development. International Journal of Sustainability in Higher Education 16 (3), pp. 385-401. http://dx.doi.org/10.1108/IJSHE-03-2014-0033

Kordas, O., Mulder, K., Nikiforovich, E., Segalàs, J., Pasichnyi, A., Pereverza, K., 2013. Paper 52. Advancing ESD in Ukraine: From awareness to orientation towards long-term thinking and societal needs, in Proceedings of the 6th Conference on Engineering Education for Sustainable Development. Cambridge, UK, pp. 317-325. 


\section{List of abbreviations}

CHP Combined heating and power

DH District heating

IEA International Energy Agency

IL Institutional logic

IT Institutional theory

LEAP Long-range energy alternative planning system

mPB Modular participatory backcasting

OCMS Organisational change management for sustainability

PB Participatory backcasting

PM Participatory modelling

SDG Sustainable Development Goals

ST Sustainability transitions

Td Transdisciplinarity

TdR Transdisciplinary research

TS Transition studies 


\section{Contents}

ACKNOWLEDGEMENTS V V

$\begin{array}{ll}\text { ABSTRACT VII } & \text { VI }\end{array}$

SAMMANFATTNING IX IX

АНОТАЦІЯ

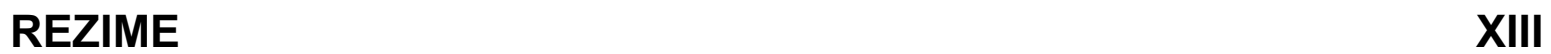

LIST OF APPENDED PAPERS XV X

ADDITIONAL PUBLICATIONS NOT INCLUDED IN THIS THESIS $\quad$ XVI

LIST OF ABBREVIATIONS XVII

1 INTRODUCTION 1

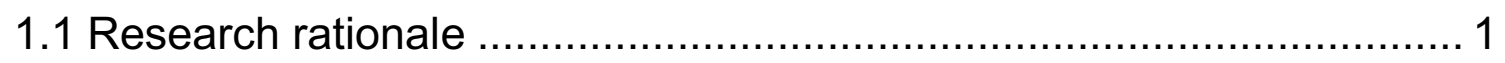

1.2 Aim and objectives ................................................................. 4

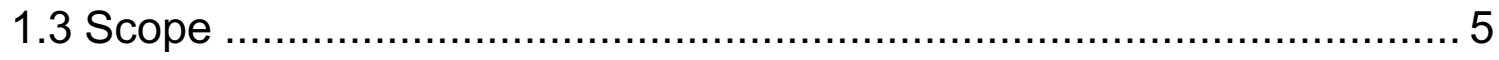

2 THE HEATING AND COOLING SECTOR 7

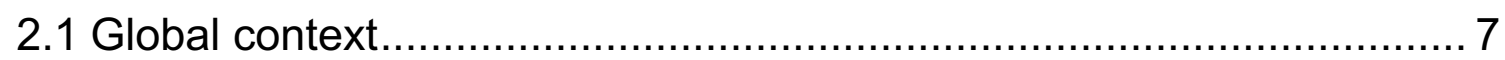

2.2 Context in Bila Tserkva, Ukraine, and Niš, Serbia ......................... 10

3 THEORETICAL BACKGROUND 13

3.1 Governance towards sustainability transitions in the heating and

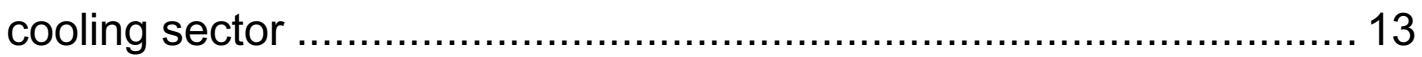

3.2 Participatory backcasting (PB): methodological developments and challenges of adaptability

3.2.1 Methodological developments of PB .............................. 15

3.2.2 Improving adaptability of PB with the use of modularity .......... 17

3.3 Scenario development, selection and analysis in PB .................... 17

3.3.1 Challenges of scenario development within PB processes ...... 17 
3.3.2 Addressing challenges with scenario development in participatory context with the use of participatory modelling .... 19

3.3.3 Morphological analysis: towards a conceptual modelling tool for scenario development and selection .

3.3.4 Urban energy system modelling: quantitative modelling for scenario analysis

3.4 Impact analysis of participatory backcasting 21

3.4.1 Research perspectives on impact analysis of PB 21

3.4.2 Addressing social scales of impact with insights from organisational change management for sustainability and institutional theory.

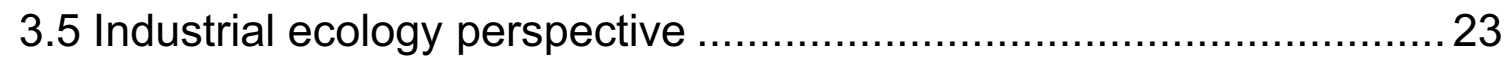

4 RESEARCH DESIGN AND METHODS 25

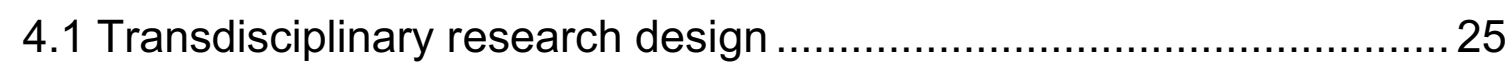

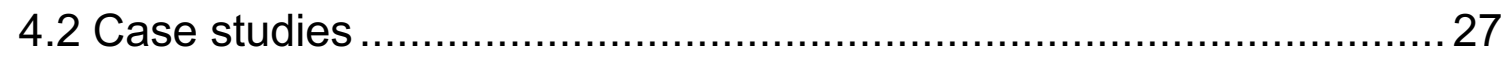

4.2.1 Case I: Sustainable heating and cooling system in Bila Tserkva, Ukraine, by 2050 . 28

4.2.2 Case II: Sustainable heating and cooling system in Niš, Serbia, by 2050 .

4.2.3 Case III: Changing practice of strategic regional planning in

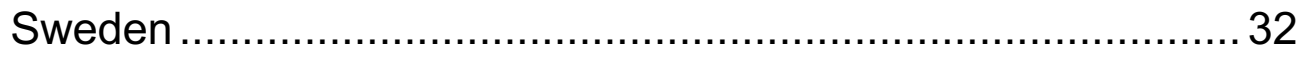

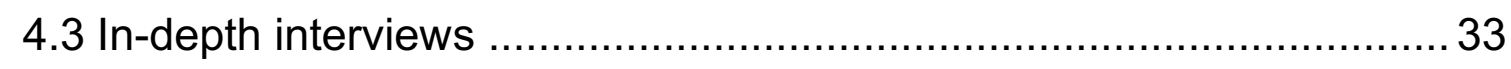

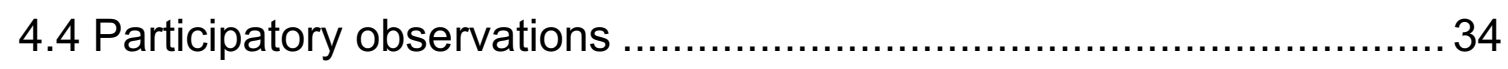

5 RESULTS AND DISCUSSION 35

5.1 Modular participatory backcasting (mPB): A strategic planning

framework for the heating and cooling sector (Paper I) 35

5.2 Participatory modelling for scenario development, selection and analysis (Papers II and III).

5.2.1 Morphological method for scenario development and selection (Paper II)

5.2.3 LEAP modelling to support scenario analysis (Paper III) 45

5.3 Social scales of the impact of participatory strategic planning processes (Paper IV). 
6 CRITICAL REFLECTIONS 51

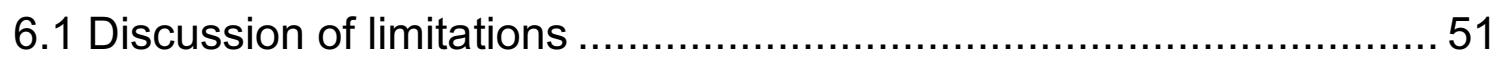

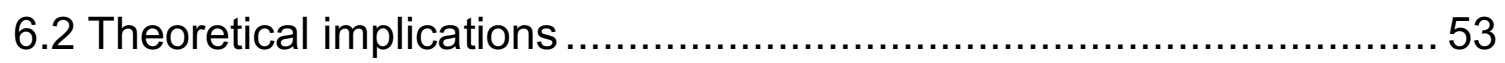

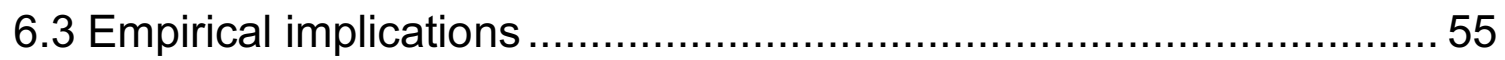

7 CONCLUSIONS $\quad 57$

8 FURTHER RESEARCH $\quad 59$

$\begin{array}{ll}\text { REFERENCES } & 61\end{array}$ 


\section{Introduction}

\subsection{Research rationale}

The heating and cooling sector is one of the largest energy sectors worldwide (Eisentraut and Adam, 2014; IEA, 2018). The sector aims to provide a comfortable indoor climate in households, public buildings, industrial buildings and commercial premises and has become an important infrastructure sector globally. Even though the heating and cooling sector has substantial potential for decarbonisation, it has only recently attracted attention in policy documents, in contrast to the electricity and transport sectors (Eisentraut and Adam, 2014; European Commission, 2016; IEA, 2018).

At present, three-quarters of final energy use for heat is provided by fossil fuels, generating around $10 \mathrm{Gt}$ of carbon dioxide $\left(\mathrm{CO}_{2}\right)$ emissions per year (Eisentraut and Adam, 2014). Moreover, the amount of energy used for cooling has tripled between 1996 and 2016 and shows a trend for further growth that would heavily increase the load on electricity systems (IEA, 2018). Other sustainability challenges in the sector include low energy security due to resource scarcity and geopolitical instability, release of nitrogen oxides $\left(\mathrm{NO}_{\mathrm{x}}\right)$ and other polluting emissions, and low energy efficiency of buildings and infrastructure (IEA, 2018; Lund, 2018). To address these challenges and deliver the United Nations' Sustainable Development Goals (SDGs), especially SDG 7: "Ensure access to affordable, reliable, sustainable and modern energy for all", fostering sustainability transitions in the heating and cooling sector is a necessary and urgent issue (Fuso Nerini et al., 2018; IEA, 2016; United Nations, 2015).

Changes towards sustainability in infrastructure sectors, such as the heating and cooling sector, are highly challenging. Challenges stem from the longevity of their material components (Loorbach et al., 2010; Markard and Truffer, 2006), the strong techno-institutional interdependencies (Markard and Truffer, 2006), the large costs involved (Bolton and Foxon, 2015; Truffer et al., 2010), interplays with other systems (Frantzeskaki and Loorbach, 2010) and a tendency to form natural monopolies and the fact that these are public utilities or social goods (Bolton and Foxon, 2015). As in other sectors, systemlevel changes in the infrastructure sector would require coordination and 
steering of many diverse actors and resources (Smith et al., 2005). Such coordination can be achieved with the help of strategic planning activities.

A number of requirements have been identified for planning activities towards sustainability in infrastructure sectors. For example, they need to be reflexive and participatory (Voß et al., 2009), adopt a long-term and more holistic perspective (Frantzeskaki and Loorbach, 2010; Truffer et al., 2010), extend governance beyond a single sector (Fuso Nerini et al., 2018) and observe openness and transparency (Frantzeskaki and Loorbach, 2010; Fuso Nerini et al., 2018). While these requirements are suggested for infrastructure sectors in general, the specificities of a particular sector are also important. The specificities of the heating and cooling sector include its dependence on local circumstances (e.g. climate, available resources, demand for heat and cold) and often the urban level of governance (Eisentraut and Adam, 2014; Späth and Rohracher, 2015; Werner, 2017). All these general and specific requirements should be considered when seeking to identify and promote a sector-appropriate strategic planning approach. For the heating and cooling sector, one such approach can be participatory backcasting.

Participatory backcasting $(P B)$ is a long-term planning approach initially developed in the energy field (Lovins, 1979, 1976; Robinson, 1982). Major developments in PB have been undertaken in Canada (Robinson, 2003; Robinson et al., 2011), Sweden (Dreborg, 1996; Holmberg and Robert, 2000) and the Netherlands (Jansen, 2003; Quist and Vergragt, 2006). The defining features of the approach are its normativity, through the development of a desirable future vision followed by elaboration of a pathway to achieve this vision, its long-term orientation and its focus on consensus building among different actors. Further, PB has been noted for its potential to bring about social learning (Robinson et al., 2011) and strategic learning (Neuvonen and Ache, 2017) and for having a positive effect on the democratisation of policymaking (Sisto et al., 2016).

In recent decades, the geography and empirical domains of $\mathrm{PB}$ applicability have been considerably broadened. For example, PB has been implemented in Ireland to address sustainable heating (Doyle and Davies, 2013), in Spain to improve the transport sector (Soria-Lara and Banister, 2017) and in Uruguay to work towards national transformations in agriculture (Kanter et al., 2016). This has resulted in a diversity of PB modifications and interpretations. However, comparable participatory governance approaches, e.g. transition management (Kemp and Loorbach, 2006), are reported to face challenges with transfer to a novel context (Heiskanen et al., 2009). These challenges are due to the complexities and ambiguities of the approach itself, carriers of the 
approach and the prevailing conditions in the context where it would be applied (Heiskanen et al., 2009). In contrast to transition management, no such analysis has yet been performed for $\mathrm{PB}$, leaving the question of its transferability unanswered. However, for a locally specific sector such as heating and cooling, a planning framework that is readily transferable to the local context would be highly beneficial.

Scenario development, selection and analysis are important components of PB processes. Scenarios are used to develop more robust pathways towards a desirable future vision and explore a diversity of alternative system configurations and a variety of possible future conditions. In many PB processes, scenarios are developed in a purely participatory way (Kok et al., 2011; Reed et al., 2013) based on e.g. intuitive logic approaches (Foster, 1993; Wack, 1985). While this form of scenario development allows for the creation of scenarios more relevant to the perceptions and knowledge of the stakeholders involved, it can suffer from limitations relating to reluctance to consider outside-the-box options, groupthink effects, dominance of one or a few individuals and challenges to outside-the-box thinking (Bryant and Lempert, 2010; Wright et al., 2013). Furthermore, to address the need for strategic planning in the heating and cooling sector, more stringent and transparent approaches to scenario development and analysis are required. For example, the use of modelling, which is rather well developed in the energy field (e.g. Keirstead et al., 2012; Urban et al., 2007), can improve understanding of a system's complexity and dynamics, guide data collection, highlight uncertainties and raise new questions (Epstein, 2008). However, modelling can suffer from challenges such as the influence of hidden assumptions, the risk of simplifications, difficulties in uncertainty analysis and ambiguities in model interpretation (McDowall and Geels, 2017). Allowing modelling and participatory processes to co-inform each other, using their advantages and compensating for their limitations, would strengthen the reflexivity and transparency of $\mathrm{PB}$-based strategic planning in the heating and cooling sector.

Wider use of $\mathrm{PB}$ in strategic planning could be enabled by a better understanding of its potential to effect changes in society. Impacts of PB have been addressed in the literature, with the focus on its long-term effects (Quist, 2007), bringing valuable insights regarding time scales (Hassenforder et al., 2015) of its impact. However, social scales (within and beyond a group of active participants) and spatial extent (within and beyond the area where a process is implemented) (Hassenforder et al., 2015) remain understudied. While various positive effects of $\mathrm{PB}$ have been reported, e.g. social learning, strategic learning and support of outcomes of a PB process, it often remains 
unclear to what level, individual or organisational, they refer. Moreover, stakeholders in the heating and cooling sector are mainly organisations (e.g. district heating companies, resource supply companies, local authorities) or formal and informal groups of individuals (e.g. non-government organisations and associations of apartment owners) that can be involved in a participatory process only through individual representatives. Therefore, addressing social scales of $\mathrm{PB}$ impact by identifying factors that could enable/prevent insights achieved on individual level from being transferred to group or organisation level would be particularly relevant for the use of $\mathrm{PB}$ in the heating and cooling sector.

\subsection{Aim and objectives}

The overall aim of this thesis is to advance strategic planning towards sustainability in the heating and cooling sector and to contribute to impact analysis of participatory planning processes.

Specific objectives of the work were to:

Objective 1 Develop a strategic planning framework for the heating and cooling sector based on $\mathrm{PB}$ and examine its adaptability to a local context (Paper I).

Objective 2 Develop methods for scenario development, selection and analysis to allow for co-informing between modelling and participatory processes within PB-based strategic planning (Paper II, Paper III).

Objective 3 Identify factors that could influence social scales of the impact of participatory strategic planning processes (Paper IV).

Objective 1 focuses on the overall design of a framework for participatory strategic planning, while Objectives 2 and 3 are concerned with particular aspects of strategic planning processes (Figure 1). 
OBJECTIVE 1. ADAPTABLE STRATEGIC PLANNING FRAMEWORK

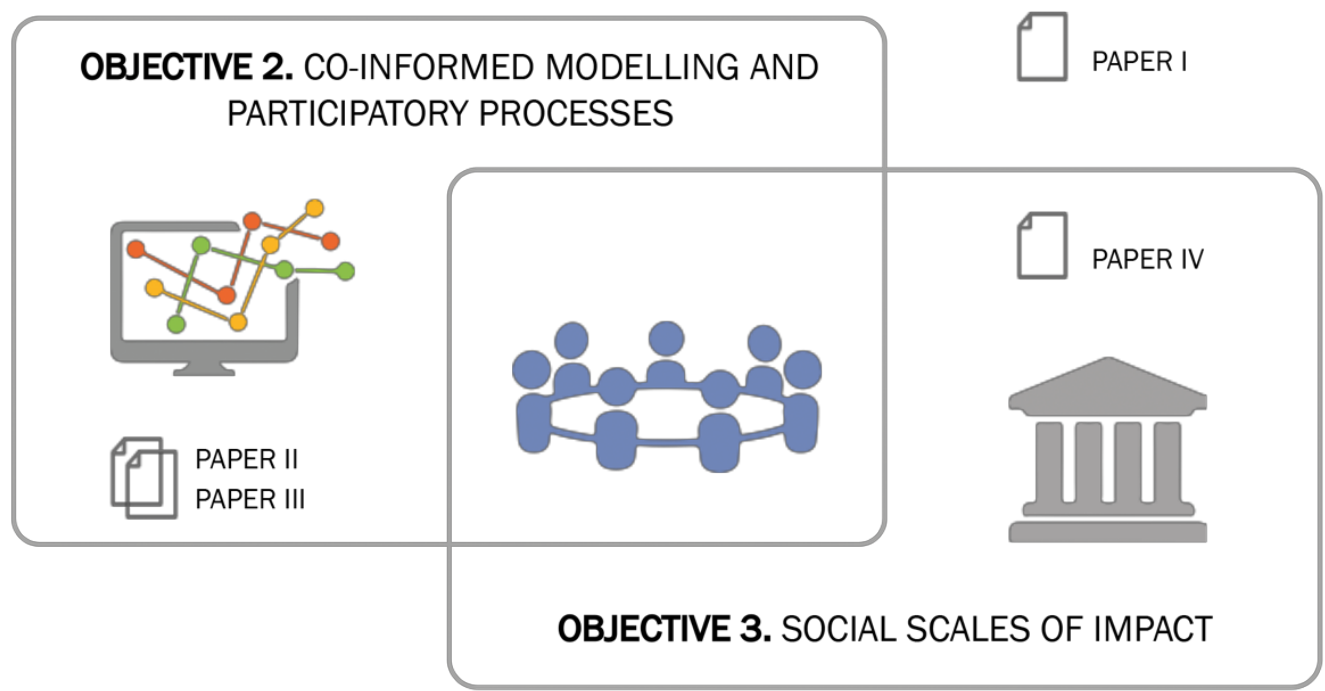

Figure 1: Interconnection of the three research objectives addressed and papers included in this thesis.

\subsection{Scope}

In this thesis, participatory strategic planning in the heating and cooling sector was studied in the context of two cities in post-socialist countries: Bila Tserkva, Ukraine, and Niš, Serbia. Changes towards sustainability in the sector are greatly important for both cities, which struggle with low energy efficiency of building and heating infrastructures, low energy security, low affordability of heating services for many citizens, a lack of funds for system maintenance, high levels of emissions harmful to human health (e.g. $\mathrm{NO}_{\mathrm{x}}$ ) and high levels of $\mathrm{CO}_{2}$ emissions (EBRD, 2011; IEA, 2016; The City of Niš, 2014). Figure 2 shows the geographical location and presents basic facts about the cities.

Participatory approaches and long-term planning of urban infrastructures have not been used previously in either city. The willingness of local authorities in both cities to experiment with a novel PB-based framework for strategic planning, a proactive attitude among local researchers and their eagerness to engage a broader range of stakeholders in a strategic planning process, and the ambition to develop capacities relevant for strategic planning (e.g. long-term and system thinking) made it possible to investigate Objectives 1 and 2. $\mathrm{PB}$ projects in both cities have been initiated and implemented as part of EU-funded projects, the FP7 project "ERAIHM" (Grinchenko et al., 2013) 
in the Ukrainian case and the Tempus project "SDTrain" (Zivkovic et al., 2015) in the Serbian case. See Section 2.2 of this thesis and Papers I, II and III for more details about the contexts in the case cities and Sections 4.2.1 and 4.2.2 for descriptions of their use as case studies.

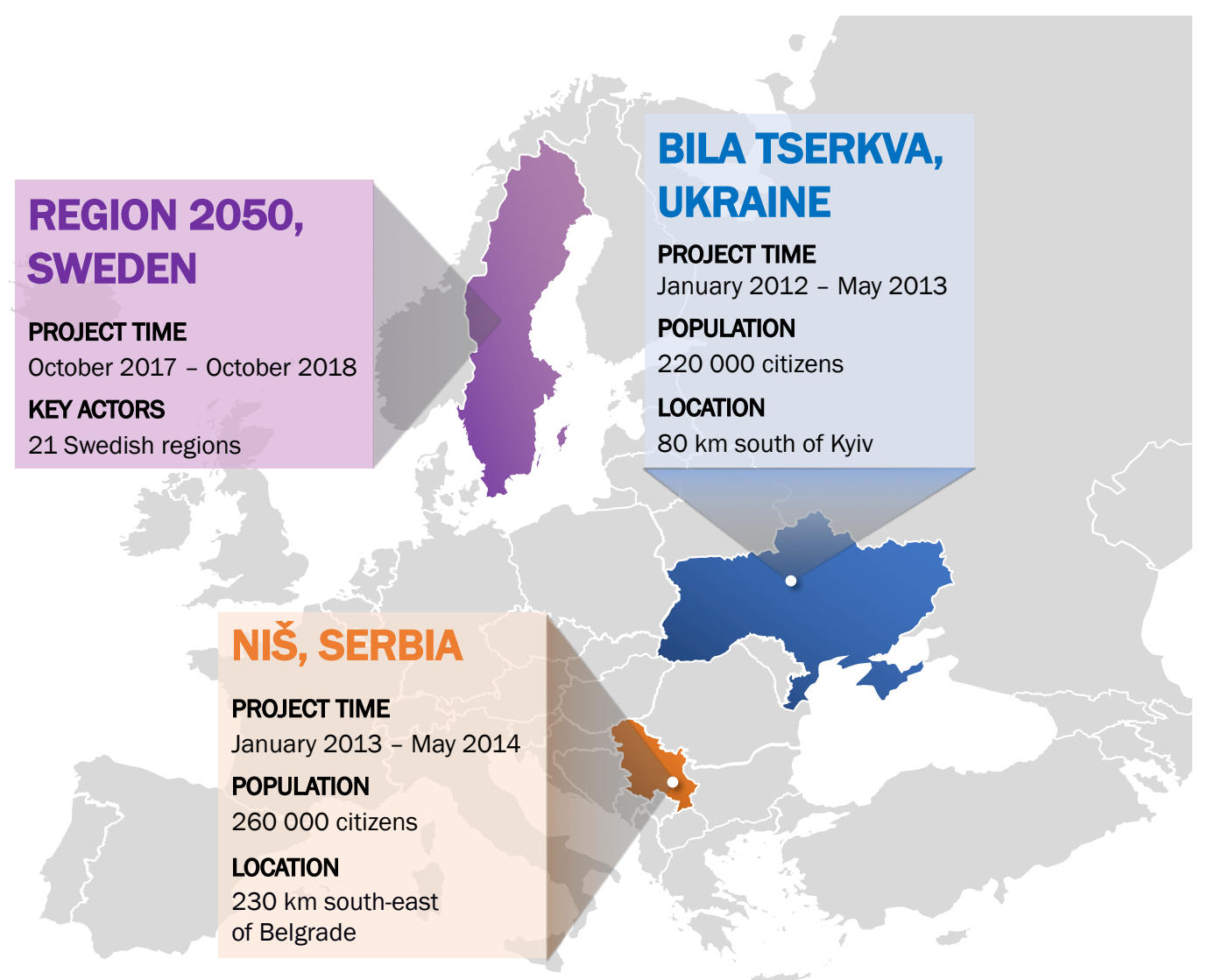

Figure 2: Geographical location and basic facts on the case cities: Bila Tserkva, Ukraine, and Niš, Serbia, and the Region 2050 project (adapted from Blank map of Europe by Nordwestern, available under CC BY-SA 4.0).

Objective 3 was addressed in the context of a project aimed at advancing the practice of strategic planning in Swedish regions, Region 2050 (Reglab, 2018) (see Figure 2 for the geographical location and basic facts about the project). Due to its participatory design and the possibility to monitor the responses of the organisations involved to the process outcomes, this case provided an opportunity to investigate factors that can contribute to the impact of participatory processes on organisational changes. See Paper IV for more details about Region 2050 and Section 4.2.3 for more details about its use as a case. 


\section{The heating and cooling sector}

\subsection{Global context}

Heating and cooling are important for providing a comfortable indoor climate in private households, public sector buildings, commercial buildings and industrial premises. Both heating and cooling are gaining increasing attention in policy and strategic documents in light of their potential to contribute to decarbonisation of energy use, increased energy efficiency, energy security, affordability and reliability of heating and cooling services, and improved air quality in cities (Eisentraut and Adam, 2014; European Commission, 2012; IEA, 2018). Heating and cooling are generally regarded as two distinct energy sectors, but in this thesis they are analysed as tightly connected parts of a unified heating and cooling sector. Important drivers for change in this sector include an increased focus on environmental sustainability due to the threat of climate change (European Commission, 2012; IEA, 2018), growing urbanisation and densification of urban areas (Heat Roadmap Europe, 2013; Werner, 2017), geopolitical instability, resource scarcity, changing ownership and liberalisation of energy markets (Heat Roadmap Europe, 2013; Werner, 2017; IEA, 2018), and changing consumer habits and lifestyles (IEA, 2018). Other drivers are the development of innovative renewable-based technologies and the growing role of information and communication technology (ICT), enabling e.g. big-data analytics for energy (Pasichnyi et al., 2019).

The above-mentioned factors influence the decision-making environment in the heating and cooling sector, making it more complex and uncertain. Current decision making in the sector is characterised by a growing range of innovative solutions available for heat and cold provision, closer interrelations with other sectors (e.g. waste, electricity, water), an increased number of actors with potentially conflicting interests involved in the sector, and a need to balance a set of diverse decision-making criteria related to social, economic and environmental sustainability (IEA, 2018; Werner, 2017). Furthermore, existing systems for heating and cooling can influence decisions regarding possible changes in the sector through e.g. various lock-in mechanisms (Gabillet, 2015).

Currently, a great variety of system configurations are used to provide heat in different countries and cities. These configurations are characterised by 
different technologies, actors and institutions found along the supply chain, from resources supply to heat demand. For example, a rather widespread system in the Nordic countries, China and post-Soviet countries in Eastern Europe is district heating (DH), which can be based on different fuels (e.g. heat oil, coal, natural gas, geothermal energy, combustible renewables and others), operated by public utilities (e.g. in many cities in Ukraine and Serbia) or private or partly private companies (e.g. in Stockholm) and powered by co-generation power plants (combined heating and power (CHP) plants) or thermal plants (Frederiksen and Werner, 2013; Werner, 2017). Another common system configuration found in e.g. the UK is a natural gas grid connected to individual boilers installed in buildings (Bolton and Foxon, 2015; Hawkey et al., 2013). Electricity is widely used for heat generation in many European countries and worldwide (IEA, 2016). However, the most widespread solution for heat supply worldwide is based on use of combustible renewables, such as firewood, which is very common in rural areas and developing countries (IEA, 2016; Werner, 2017). It is often linked to low air quality and health problems in these areas (IEA, 2016). Although district cooling has recently been developed in service buildings in the Middle East, USA, Japan and Europe (Werner, 2017), cooling systems remain largely disconnected from heating systems and cooling is mainly provided by various air conditioners and household fans (IEA, 2018). With rising demand for cooling, enormous strain will be placed on electricity systems in many countries, creating a need to introduce solutions for more efficient use of cooling, e.g. by increasing the energy efficiency of buildings (IEA, 2018).

The technological configurations established for heating and cooling provision are reflected in the sector actors and their actor networks. Important actors are end-users, local authorities, heat and cold supply companies, grid operators, resource supply companies, equipment providers, heating and cooling generation companies, and non-government organisations (NGOs). End-users in the sector define the demand for heating and cooling and are represented by a diverse set of actors from the public sector, private households and their associations, industry, and commerce. When choosing a solution for heating and cooling, end users can be influenced by a variety of factors that prevent them from selecting a more sustainable solution. For example, for privately owned residential buildings, factors such as inefficient individual solutions for heating (e.g. natural gas boilers), lack of expertise and training, and lack of information about alternative solutions have been identified as barriers to sustainability transitions (IEA, 2016). At the same time, a growing diversity of solutions for heating and cooling is becoming available on the market. Along with novel technologies, new types of actors 
enter the sector, for example prosumers (e.g. Leal-Arcas et al., 2018), energy cooperatives (e.g. Hentschel et al., 2018), storage providers (e.g. Miller and Carriveau, 2018), and ICT companies (e.g. Nijhuis et al., 2015).

New actors and technologies bring opportunities for system innovations in the heating and cooling sector. For example, a new so-called 4th generation of district heating systems is seen as a highly efficient heat supply system. It provides possibilities for prosumers to generate heat from renewable technologies such as solar collectors and wind power-driven heat pumps connected to a smart thermal grid, and for waste heat and heat from municipal waste incineration to be integrated into the system (e.g. Lund, 2018; Lund et al., 2014; Persson et al., 2014). Other innovative technologies for more sustainable heating and cooling are small-scale CHP systems (e.g. Patuzzi et al., 2016; Salomón et al., 2011), heat storage (e.g. Hedegaard et al., 2012; Romanchenko et al., 2018), solar heating and cooling systems (e.g. Buonomano et al., 2018; Lundh and Dalenbäck, 2008), utilisation of heat from large electricity users such as large data centres (e.g. Davies et al., 2016; Ebrahimi et al., 2014) and low-temperature grid technologies (e.g. Averfalk et al., 2017; Bach et al., 2016; Matovic, 2011). Carbon sequestration technologies are promising for mitigation of $\mathrm{CO}_{2}$ emissions from heating and cooling production (e.g. McDonough et al., 2018; Vinca et al., 2018). In parallel, the demand for heating and cooling can be reduced by increasing the energy efficiency of buildings up to the level of zero-energy buildings (e.g. Kylili and Fokaides, 2015), development of eco-districts (e.g. Gabillet, 2015; Perez et al., 2018) and implementation of novel methods and tools for demand-side management, e.g. demand-response mechanisms (e.g. Nilsson et al., 2018) and urban energy data analytics (e.g. Pasichnyi et al., 2019).

Furthermore, strategies built upon synergies in energy systems and other infrastructure sectors are seen as promising for reaching ambitious sustainability goals (e.g. Persson et al., 2014). Relevant solutions include DH systems, combined heat and power (CHP) co-generation plants and smart buildings, but also rather novel trigeneration systems that combine heating, cooling and electricity generation (Leonzio, 2018; Pina et al., 2018) and allowing for heating and cooling transfer over the same grid (Nakao et al., 2018). Advanced system integration solutions can be developed based upon the principles of industrial ecology (e.g. Vernay et al., 2013). For example, the idea of integrating material and energy flows underlines the so-called 'Hammarby model' implemented in the city district Hammarby in Stockholm (Pandis Iveroth, 2014). Similarly, the use of municipal waste for heat generation, as part of a waste-to-energy strategy, is seen as an important contributor to improvement of waste management in the context of the 
circular economy in Europe (Malinauskaite et al., 2017). Efficient ventilation and air conditioning are extremely important for providing a comfortable indoor climate, along with heating and cooling supply, and can lead to a significant reduction in power consumption (Jouhara and Yang, 2018), as part of a net-zero strategy for buildings (Wu and Skye, 2018). Finally, it is important to recognise that some of the available solutions can represent potentially conflicting options, e.g. development of net-zero energy buildings/eco-districts in cities with an existing or planned CHP-based DH system can create tensions due to contradictory views of e.g. energy utilities and planning departments in cities (Gabillet, 2015; Späth and Rohracher, 2015).

To sum up, sustainability transitions in the heating and cooling sector could be enabled by a broad range of alternatives that have different long-term consequences and different starting points defined by locally developed sociotechnical configurations for heating and cooling. The high complexity of the heating and cooling sector and recent changes in its decision-making environment (e.g. closer interrelations with other sectors, involvement of an increased number of actors with potentially conflicting interests, the need to balance a set of diverse decision-making criteria) create a need for changing the approach to planning and decision making in the sector. Sector stakeholders can be both enablers and barriers to change. Their involvement in contextualisation of visions of a future system and in making strategic choices is thus crucial for the successful development of robust transition pathways in the sector, based on a diversity of perspectives and knowledge about various aspects of the system.

\subsection{Context in Bila Tserkva, Ukraine, and Niš, Serbia ${ }^{1}$}

The heating and cooling sector in both Ukraine and Serbia accounts for a large share of energy consumption and was mainly based on the use of fossil fuels such as natural gas, coal and oil (EBRD, 2011; IEA, 2016). In single-family houses in many Ukrainian and Serbian cities, the use of combustible renewables was also common, e.g. in Niš firewood accounted for $31 \%$ of final energy use for heating in the household sector (The City of Niš, 2014). In 2012-20132, Bila Tserkva, like other Ukrainian cities, was dependent on the use of natural gas for heating, both in CHP plants and in individual boilers

\footnotetext{
${ }^{1}$ This section is largely based on the outcomes of current situation analysis performed as a part of PB projects implemented within the scope of this thesis work.

${ }^{2}$ Timeframe of data collection in Bila Tserkva case.
} 
connected to the widespread natural gas grid (EBRD, 2011; Wolczuk, 2016). In $2014-2015^{3}$ in Niš, locally produced lignite (brown coal) was the main resource used for electricity generation and electricity-based heaters and fans were mainly used for heating and cooling in the household sector, while natural gas was the main resource (91\%) used for heat generation in a $\mathrm{DH}$ system that covered almost $61 \%$ of head demand in public sector and $29 \%$ in the household sector (The City of Niš, 2014). Energy security in both cities was rather low at that time, mainly due to a low level of resource diversification and reliance on imported natural gas for heat generation (80\% of natural gas in Niš and 100\% in Bila Tserkva was imported from Russia) (Ministry of the Fuels and Energy of Ukraine, 2012; The City of Niš, 2014). Because of rather low energy efficiency of buildings and heat distribution infrastructure, the distribution losses of heat were also quite high (OECD/IEA, 2006). In both cities, the DH system was initially designed in the 1970 s according to the now outdated standard of second/third generation $\mathrm{DH}$ that assumes the use of fossil fuels and buildings with high heat demand (Werner, 2017).

The situation described above led to a number of sustainability challenges. These were high emissions of $\mathrm{CO}_{2}, \mathrm{NO}_{\mathrm{x}}$ and other pollutants, low energy security and low energy efficiency in both countries (IEA, 2016; IEA, 2018). However, these challenges were not on the agenda for policymakers at the local and national level and were obscured in public discourses in both cities. In Bila Tserkva, the situation was further complicated by a lack of mechanisms that can be implemented on the urban level, due to the low level of city autonomy. For example, the city council could not influence heat tariff formation and invoicing of heat services for citizens. Thus, in Bila Tserkva, heating was invoiced using a lump sum scheme, providing no incentive to the heating company or customers to improve their energy efficiency (Grinchenko et al., 2013). In contrast, Niš was among the first cities in Serbia to develop and adopt (in 2014) a Sustainable Energy Action Plan (SEAP) (The City of Niš, 2014), which is a promising example of a city initiative towards more sustainable energy use.

In both cities, local authorities were responsible for heating infrastructure planning and development, but different parts of the system were managed by different private and public actors. For example, in Bila Tserkva, CHP and the connected heating grid were privately owned, while the distribution grid in buildings was operated by a public company (Grinchenko et al., 2013). Different types of consumers (e.g. single family and multi-story buildings, public buildings such as hospitals and schools) had certain flexibility in

3Timeframe of data collection in Niš case. 
choosing what type of heating to use, but were commonly unaware of existing alternatives, especially renewables-based alternatives. Furthermore, in Bila Tserkva disconnection from $\mathrm{DH}$ was prohibited for individual apartments, to maintain a certain level of heat demand for the DH system (Grinchenko et al., 2013).

The context for governance in the heating and cooling sector in Ukraine and Serbia has changed considerably over the past 20 years, becoming more complex and uncertain. The reasons include the recent liberalisation of energy markets, privatisation of parts of the energy system in the 1990 s and 2000 s (Werner, 2017), a complicated geopolitical situation for both countries (Wolczuk, 2016) and a low level of civil society development (Grødeland and Aasland, 2011). In this situation, neither bottom-up initiatives nor top-down actions and policies seeking to achieve sustainability of heating and cooling have been created. Lock-in to the established system has been reinforced by lack of mechanisms or motivation to initiate changes by public companies involved in heat infrastructure, relatively minor awareness of sustainability challenges among the population and a minor role of sustainability issues in public discourses, unexplored potential of locally available renewables (e.g. wind, solar, hydropower), municipal waste, industrial waste heat and other potential resources for heating and cooling, lack of investment, and lack of innovation policies.

Similarly to the global situation, the dominant modes of planning in the heating sectors in Ukraine and Serbia were not equipped for the current decision-making environment. The planning modes were rather short-sighted and based on system improvement/optimisation approaches, technoeconomic criteria and top-down forms of governance (e.g. Lankina et al., 2017; Tešić et al., 2011). In addition, collaborations between different heating system stakeholders, and particularly between public sector actors and researchers, were almost non-existent (e.g. Yegorov, 2009). Introducing novel and more appropriate approaches for planning, increasing the transparency of planning processes and involving a broader range of actors in planning would be beneficial for both cities and can contribute to the initiation of sustainability transformations. 


\section{Theoretical background}

\subsection{Governance towards sustainability transitions in the heating and cooling sector}

Complex and transformative changes, such as sustainable development, demand suitable forms of governance to guide them (Voß et al., 2009). This is relevant across a variety of fields, including infrastructure sectors, such as heating and cooling. This thesis approaches an infrastructure sector as a sociotechnical system. A socio-technical systems perspective makes it possible to explore interconnections among actors, technologies and institutions that enable functioning of a system and influence possibilities for its transition (Grin et al., 2010; Hughes, 1983). Transitions are understood as reconfigurations of socio-technical systems through co-evolution of technologies and institutional structures (Geels, 2004) and are regarded as "large-scale disruptive changes in societal systems that emerge over a long period of decades" (Loorbach et al., 2017, p. 600). In the case of sustainability transitions, these changes are intended to lead to a more sustainable system configuration.

Studies of sustainability transitions in infrastructure systems reveal specific characteristics of this type of system that can influence opportunities and challenges for steering them towards sustainability. Thus, infrastructure systems can be characterised by longevity of their material components (e.g. heat distribution grid, CHP, buildings) and strong techno-institutional interdependencies (Markard and Truffer, 2006), the large costs involved in their development, functioning and phase-out and the large number of actors and institutions involved (Loorbach et al., 2010), and interplays with other systems, e.g. in the form of competition, interdependence and joint use (Frantzeskaki and Loorbach, 2010). Furthermore, such systems are often public utilities or social goods and tend to form natural monopolies, meaning that the services provided may not be traded in markets, but are rather the subject of influence by the state (Bolton and Foxon, 2015). Such characteristics lead to a situation where, once built, infrastructure systems can be locked into unsustainable trajectories for many decades (Bolton and Foxon, 2015; Truffer et al., 2010).

While planning of infrastructure systems can play a potentially key role in avoiding such unsustainable paths, the current dominant approach to 
planning in infrastructure sectors is not equipped to address the situation (Malekpour et al., 2015; Truffer et al., 2008). It is characterised by a shortterm perspective, reactivity and an overall focus on system optimisation (Malekpour et al., 2015; Truffer et al., 2010). It has been suggested that more appropriate planning approaches to enable the creation of alternative visions and system innovations are needed (Elzen et al., 2004; Malekpour et al., 2015; Truffer et al., 2010). Recent studies have revealed a number of requirements for such novel planning approaches, including reflexivity and a participatory nature (Frantzeskaki and Loorbach, 2010; Truffer et al., 2010), a long-term perspective (Fuso Nerini et al., 2018; Truffer et al., 2010), openness and transparency (Truffer et al., 2010), a holistic perspective and governance beyond the single sector (Cass et al., 2018; Fuso Nerini et al., 2018), and flexibility and robustness (Kucharski and Unesaki, 2018).

To address these requirements, a number of recently developed governance mechanisms can be of use. They include visioning and mapping expectations (Truffer et al., 2008), rethinking/changing the roles of currently involved actors and empowerment of new actors (Avelino and Wittmayer, 2016; Wittmayer et al., 2016), building and supporting transition arenas (Frantzeskaki et al., 2012) and articulation and modelling of long-term pathways (Köhler et al., 2018; Voß et al., 2009). In addition, experimentation with alternative system designs on a real-life scale and exploration of interventions are suggested to be useful (Frantzeskaki and Loorbach, 2010; Loorbach et al., 2017).

Several planning frameworks built according to the requirements outlined above and some of the suggested mechanisms have been developed and tested in different infrastructure sectors. For example, a regional infrastructure foresight approach has been developed and demonstrated for the sanitation sector (Störmer et al., 2009) and urban water infrastructure (Truffer et al., 2010), participatory exploratory modelling has been developed and used to support long-term planning of energy transitions (Moallemi and Malekpour, 2018), and participatory modelling processes have been developed and applied to support water resources management (Halbe et al., 2018).

While all infrastructure systems have numerous similarities and features in common, they also have their own specific features (specificities) and these could determine the governance approaches that are effective for a particular system. For example, infrastructure systems can have different architectures, e.g. distributive (electricity, water), accumulative (sewerage and waste disposal) and communicative (transport), that influence possible pathways along which a system can change (Frantzeskaki and Loorbach, 2010). The 
heating and cooling sector also possesses a number of specificities, as discussed in Chapter 2. These include its substantial dependence on local conditions (e.g. locally available resources, climate and other cultural and socio-economic factors), the physical impossibility of heating and cooling transfer over long distances and the localised nature of negative effects (e.g. the influence of $\mathrm{NO}_{\mathrm{x}}$ emissions on the health of local residents). Consequently, the sector is often governed and planned on the urban level. However, planning on the urban level increases the risk of (i) the urban trap (Purcell, 2006) and (ii) the urban junction (Jensen et al., 2015) arising in the heating and cooling sector. The urban trap involves a tendency to assume that the administrative boundaries of a city are the most suitable for strategic planning in the heating and cooling sector. The urban junction means that planning in the sector happens in a context of highly interconnected systems, infrastructures and practices with blurred boundaries. To address this risk and acknowledge the arbitrary nature of system boundaries (Meadows, 2008), explicit consideration of system boundaries is needed, along with navigational or planning activities based on negotiation, mediation and consensus building among different perspectives and interests of a broad range of actors, including all conventional system actors (Jensen et al., 2015; Späth and Rohracher, 2015; Paper I). Considering these specificities of the heating and cooling sector, participatory backcasting (Jansen, 2003; Quist, 2007) was tested in this thesis as a potentially suitable approach for development of a strategic planning framework for the sector.

\subsection{Participatory backcasting (PB): methodological developments and challenges of adaptability}

\subsubsection{Methodological developments of PB}

Participatory backcasting (PB) is a long-term planning approach that entails development of a desirable future vision and further elaboration of a pathway towards this vision (Quist, 2007). Backcasting initially emerged in the energy field in 1976, when Lovins suggested "backwards-looking analysis" to support his "soft energy path" vision of future energy systems. The concept of backwards-looking analysis was later advanced by Robinson (1982) as a policy analysis tool, energy backcasting. In the 2000s, backcasting was refined for use within participatory processes in the Netherlands (Jansen, 2003; Quist, 2007), Canada (Robinson, 2003) and Sweden (Dreborg, 1996; Holmberg and Robert, 2000). 
Participatory backcasting possesses a number of characteristics that make it relevant for use in a strategic planning framework for the heating and cooling sector. These include normativity, long-term orientation and a focus on consensus building among different actors (Jansen, 2003; Quist and Vergragt, 2006). Normativity allows development of a shared desirable future vision by the stakeholders involved. Such a vision can have a strong guiding power for changes in the sector (Quist, 2007). Long-term orientation is important for planning in a complex and uncertain environment when system innovations are only possible if long-term goals are reflected in short-term actions. Finally, consensus building among different actors is particularly relevant for a heating and cooling sector that is often governed in the context of urban junction (Jensen et al., 2013; Späth and Rohraher, 2015).

Other important features of $\mathrm{PB}$ concerning planning in the heating and cooling sector are its focus on needs and functions instead of promoting a particular technology and the local contextualisation of visions and criteria by leaving them up to definition by local stakeholders (Jansen, 2003; Quist, 2013). There are different approaches to local contextualisation in PB studies. For example, the Natural step approach to backcasting (Holmberg and Robert, 2000) suggests the usefulness of a pre-defined set of sustainability principles to be provided to stakeholders. In spite of methodological flexibility, the most often used PB framework, refined in Quist (2007), includes five steps: Step 1 Strategic problem orientation; Step 2 Development of future vision; Step 3 Backcasting analysis; Step 4 Elaboration of future alternative and definition of follow-up agenda; and Step 5 Embedding results and agenda and stimulation of follow-ups.

The geography and empirical domains of PB applicability have already been broadened beyond the area of its conventional development. For example, PB has been used to address transition towards sustainable lifestyles in five European cities (Carlsson-Kanyama et al., 2008); sustainable heating in Ireland (Doyle and Davies, 2013); the water sector on European level (Kok et al., 2011); city planning in Sweden (Phdungsilp, 2011); sustainable energy consumption in Sweden (Svenfelt et al., 2011); the transport sector in Spain (Soria-Lara and Banister, 2017); and national agricultural transformations in Uruguay (Kanter et al., 2016). While these studies indicate the potential of $\mathrm{PB}$ for application in a variety of contexts and situations, they do not explicitly address its adaptability and transferability to different contexts.

For the transitions management (Kemp and Loorbach, 2006) approach to participatory governance, challenges associated with its transferability have 
been identified (Heiskanen et al., 2009). These challenges are caused by complexities and ambiguities of the approach that have led to only partial adoption of its particular elements in actual cases (Heiskanen et al., 2009). Challenges with transferability could also apply to PB, e.g. important features of PB outlined above can be 'lost in translation' or misinterpreted when transferred to a novel context. The overall aim of this thesis was to advance PB methodologically through a novel design, based on the principle of modularity, in order to increase its transferability and adaptability.

\subsubsection{Improving adaptability of PB with the use of modularity}

Modularity is a concept used in various research fields, from biology to engineering and organisational management. In a broad sense, it can be understood as the degree to which system components can be separated (Baldwin et al., 2014; Langlois, 2002). According to the definition by Baldwin et al. (2014, p.1383), a module is characterised by "the interdependence of decisions within modules; the independence of decisions between modules; and the hierarchical dependence of modules on components embodying standards and design rules". While the degree of connection can differ and gradations of modularity can be applied, the modular design makes the decisions within modules more interdependent than those between modules (Baldwin and Clark, 2000).

For modularisation, three design components must be specified: architecture (the modules that will be part of the system and their functions), interface (how the modules will interact, fit together and communicate) and standards (modules conformity to design rules and relative performance) (Baldwin and Clark, 1997; Langlois, 2002) Through its properties of splitting, exclusion, augmentation, substitution, inverting, and porting, modularity enables a more flexible design and also a higher level of detail and specification of expected system performance (Baldwin and Clark, 2000). For a description of how the principle of modularity was applied in this thesis to increase the adaptability of $\mathrm{PB}$, see Section 5.1.

\subsection{Scenario development, selection and analysis in PB}

\subsubsection{Challenges of scenario development within PB processes}

In $\mathrm{PB}$, scenarios can contribute to the development of more robust pathways towards a desirable future vision based on exploration of a diversity of alternative system configurations against a variety of possible external 
conditions (Quist, 2013). Two types of scenarios relevant for PB studies have been identified. The first type is external scenarios, i.e. possible futures formed by external factors that are beyond the direct control of actors involved in a PB process (Godet, 2006). The second type is internal scenarios (or solutions), i.e. possible configurations of a system in the future that are to some extent under the control of the actors (Godet, 2006).

Development, selection and analysis of scenarios within PB processes can be carried out using different approaches ranging from purely participatory to processes based on the use of quantitative modelling. Each type of method has its benefits and limitations. For example, it has been shown that stakeholder participation in scenario development can result in scenarios that are more relevant for stakeholders' needs and priorities (Kok et al., 2011; Reed et al., 2013) and can increase the number of details in scenario descriptions (Reed et al., 2013). However, the use of intuitive logic approaches to scenario development (Foster, 1993; Wack, 1985) can suffer from limitations relating to cognitive biases, groupthink effects, dominance of one or a few individuals and challenges to outside-the-box thinking (Bryant and Lempert, 2010; Wright et al., 2013).

Quantitative modelling can strengthen the quality of scenario analysis by providing the possibility to systematically assess the options available to decision-makers under a wide range of potential external conditions and explore the long-term consequences of different options (e.g. Holtz et al., 2015; Moallemi and Malekpour, 2018). For example, analytical and modelling approaches such as multi-criteria analysis (Anderson et al., 2008; Mander et al., 2008), GIS-based modelling (Haslauer et al., 2012) and fault-tree analysis (Kishita et al., 2017) have been demonstrated to be beneficial for the quality of PB outcomes. However, modelling can suffer from the influence of hidden assumptions, the risk of simplifications, challenges in uncertainty analysis and ambiguities in model interpretation (McDowall and Geels, 2017).

This thesis sought to address the challenges related to the use of modelling and intuitive logic approaches for co-informing participatory scenario development, selection and analysis within PB. This was done based on insights from participatory modelling (Dreyer and Renn, 2011; Voinov et al., 2016), transdisciplinarity (Lang et al., 2012), morphological analysis (Ritchey, 2018; Zwicky, 1948) and urban energy system modelling (Keirstead et al., 2012). 
3.3.2 Addressing challenges with scenario development in participatory context with the use of participatory modelling

Participatory modelling (PM) can be broadly defined as an approach that allows modelling and participation to be linked (Dreyer and Renn, 2011). It assumes a possibility to integrate different types of models in a PB process, e.g. analytical, data-driven and optimisation models (Basco-Carrera et al., 2017). Many PM studies have explored the use of quantitative modelling based on Bayesian networks (Carmona et al., 2013; Maskrey et al., 2016), multi-criteria analysis (Mendoza and Prabhu, 2005) and exploratory modelling (Moallemi and Malekpour, 2018). Attention has also been drawn to the potential of conceptual modelling (e.g. Boman et al., 1997) to support participatory planning and decision making, e.g. the use of causal loop diagrams for the development of transition pathways has been demonstrated (Halbe, 2016).

Participatory modelling processes can include different components. For example, it can encompass all or several of the following: (a) scoping and abstraction, (b) envisioning and goal setting, (c) model formulation, (d) crosschecking of data, facts and logic, (e) model application to decision making, (f) evaluation of outputs and outcomes and (j) facilitation of transparency (Voinov et al., 2016). Previous findings in PM research indicate the importance of identification of a clear problem, engagement of stakeholders in the process of modelling as early as possible, gaining trust and acknowledging conflicts, selecting appropriate modelling tools, gaining acceptance for modelling methodology before presenting model results and incorporating all forms of stakeholder knowledge (Voinov and Gaddis, 2008). When properly applied, PM can lead to collaborative and shared learning among the participants involved, a legitimate local decision-making process, support for democratic principles and empowerment of stakeholders to move forward with a concerted effort (Basco-Carrera et al., 2017; Voinov et al., 2016).

Experience gained in the PM field also includes an improved understanding of possible limitations and challenges of PM processes. These limitations are largely related to the influence of perception, beliefs and biases of the actors involved in the PM process (Voinov et al., 2016). To overcome these challenges, there is a need for mechanisms that explicitly recognise human biases and heuristics (Kahneman et al., 1982) in a PM process and apply appropriate de-biasing techniques or compensate for bias (Hämäläinen, 2015; Voinov et al., 2016). Hämäläinen (2015) also stresses the need to dedicate more attention to the skills and behaviour of modellers, who have their own 
biases and can exert considerable influence over modelling processes (Hämäläinen, 2015). To address modeller bias, integration of transdisciplinarity in the PM process design is proposed in this thesis.

Transdisciplinarity is an approach for the development of socially robust solutions based on integration of knowledge from researchers and nonacademic actors (Scholz, 2017). Due to its strong emphasis on co-creation and collaboration between academic and non-academic actors, transdisciplinarity can enable greater reflexivity on biases and initial assumptions of both types of actors. It can also provide an opportunity for re-thinking the conventional roles of these actors in initiation and implementation of changes in the heating and cooling sector.

3.3.3 Morphological analysis: towards a conceptual modelling tool for scenario development and selection

Morphological analysis (Ritchey, 2011; Zwicky, 1948) was used in this thesis to address the limitations of the intuitive logic approach to scenario development (Wack, 1985; Foster, 1993). Morphological analysis was introduced by Zwicky as a creativity method for design of novel technical devices (Zwicky, 1948). Later, the approach was refined for the use beyond the engineering field, e.g. in policy analysis (e.g. Godet, 2006; Ritchey, 2011). Morphological analysis has also been described recently as a conceptual modelling tool (Ritchey, 2018).

Morphological analysis permits the development of a full space of possible solutions and their further examination in a systematic way (Zwicky, 1969). The approach can support the development of a large number of alternative scenarios and their systematic consideration (Godet, 2006; Godet and Durance, 2011). It has been used for computer-assisted scenario development by Ritchey (2006, 2018) and Godet (2006). For more details about morphological analysis, see Paper II.

In the context of this thesis, a morphological method for scenario development and selection, developed based on the morphological analysis in Paper II, was investigated to explore how conceptual modelling can co-inform PB processes. See Section 5.2 for a summary of findings in this regard. 


\subsubsection{Urban energy system modelling: quantitative modelling for scenario analysis}

To strengthen scenario analysis within PB-based processes, co-informing between participatory processes and quantitative modelling based on urban energy system modelling (Keirstead et al., 2012) was used in this thesis. In the energy field, quantitative modelling is a rather well-established area, with a number of different modelling tools and approaches developed (Herbst et al., 2012; Hoffman and Wood, 1976).

For the heating and cooling sector, a relevant set of models can be urban energy system models (Keirstead et al., 2012), with the Long-range Energy Alternatives Planning System (LEAP) being an example of a quantitative modelling software (Heaps, 2014). LEAP can also help to overcome some of the challenges related to energy modelling in the context of developing countries (Urban et al., 2007). LEAP allows for simulation of 'what if' scenarios under a range of user-defined assumptions on final energy demand with main parameters of scenarios introduced as exogenous inputs. For more details of approaches to energy system modelling and LEAP, see Paper III.

\subsection{Impact analysis of participatory backcasting}

\subsubsection{Research perspectives on impact analysis of PB}

Analysis of the impact of participatory approaches is a complicated question recognised in different research areas dealing with stakeholder participation in planning and decision-making. In their framework for description and comparative analysis of participatory processes, Hassenforder et al. (2015) identify three types of impact scales: social scales (within and beyond a group of active participants), spatial extent (within and beyond the area where a process is implemented) and time scales (short-, medium- and long-term). In the context of this typology, the spatial extent of $\mathrm{PB}$ impact is most thoroughly addressed by Quist (2007) in his analysis of the impact after 5-10 years of three PB processes in the Netherlands. This analysis resulted in identification of internal factors (e.g. degree of stakeholder involvement, diversity of stakeholders, degree of guidance and orientation, institutional protection, presence of vision champions) and external factors that can influence followup, spin-off and implementation in line with the vision and follow-up agenda developed within PB processes (Quist, 2007). This thesis focused on the social scales of the PB impact, addressing the potential of extending PB effects (e.g. social learning (Doyle and Davies, 2013; Robinson et al., 2011), strategic learning (Neuvonen and Ache, 2017) and support of the process outcomes 
(Quist, 2007)) beyond the individuals directly involved, e.g. to their organisations.

To address the social scales of impact of participatory strategic planning processes, insights from organisational change management for sustainability (OCMS) and institutional theory (IT) were applied in this thesis. Of these, OCMS is concerned with alignment issues among different levels in organisations, including individual, group and organisational (Lozano, 2014, 2008), and IT (Greenwood and Suddaby, 2006; Powell and DiMaggio, 1991) deals with e.g. alignment issues between different institutional logics. Incorporation of these two research pillars is a longawaited move in PB studies since it was first identified as promising by Quist (2007).

\subsubsection{Addressing social scales of impact with insights from organisational change management for sustainability and institutional theory}

Organisational change management for sustainability is a relatively recently formed sub-field of organisational change management (OCM) that specifically addresses sustainability-oriented changes. Thus, OCMS is predominantly concerned with processes within a single organisation. From an OCMS perspective, processes of collaborative decision making, such as PBbased processes, can be regarded as a source of external drivers for changes (Lozano, 2013). A better understanding of how an organisation reacts to such external drivers could improve participatory process design in a way that reinforces its influence on the organisations involved.

Findings from the OCMS literature suggest that organisational changes are only possible through alignment between individual, group and organisation levels and congruence between informational, emotional and behavioural attitudes (Lozano, 2013). The findings also suggest the importance of steering changes through leadership, value sharing, inspiration and communication (Lozano, 2013). Collaborations are stressed as important for sustainability changes, but it is pointed out that collaboration costs should not be underestimated (Lozano, 2008). To enable collaborations, the role of individuals able to connect different organisations, so-called bridgers, is important (Hamner et al., 2008).

Use of the institutional theory research pillar (Powell and DiMaggio, 1991; Thornton and Ocasio, 1999) to address the social scales of PB impact has contributed to a better understanding of the role of values, rules or taken-for- 
granted assumptions and beliefs in the processes of institutional change. Recently, concepts of institutional logic (IL) and institutional work have been brought to light in the transition studies field (Fuenfschilling and Truffer, 2014; Hassink et al., 2018; Smink et al., 2015). Institutional logic is defined as "socially constructed, historical patterns of practices, beliefs, values, and rules" (Hassink et al., 2018, p. 194). Institutional theory-based work helps to analyse actions of actors aimed at the creation, maintenance or disruption of institutions (Fuenfschilling and Truffer, 2014).

Two concepts within IT that are relevant for analysis of the social scales of PB impact are boundary spanners and institutional plurality. Boundary spanners are individuals who are able to connect different institutional logics (Smink et al., 2015). The characteristics of boundary spanners include their exposure to multiple or even contradictory logics as a prerequisite (Greenwood and Suddaby, 2006), "specific and dedicated actors" (Klerkx et al., 2010), good networking skills, effective interpersonal competencies and the ability to create trust (Williams, 2002). The concept of boundary spanners can also refer to organisations (where the term 'intermediaries' is also used, see e.g. Kivimaa (2014)).

Institutional plurality refers to the level of coherence of logics within a particular context (Fuenfschilling and Truffer, 2016). The concept of institutional logic is relevant for a PB process in which misalignment can occur: (i) in the logics of the organisations involved; and (ii) between the logic of the PB process itself and the institutional logics of the organisations involved. High institutional plurality within an organisation can increase the possibility of it having a different logic and different approaches and actions associated with this logic (e.g. those in line with PB process outcomes) to be adopted by the organisation. However, organisations can respond to competing institutional logics differently, for example, strategies of decoupling, compromising or combining logics can be applied (Pache and Santos, 2013).

For more details of the findings of OCMS and IT identified as relevant for this thesis work, see Paper IV. For a summary of the findings on the social scales of the impact of participatory strategic planning processes, see Section 5.4.

\subsection{Industrial ecology perspective}

Industrial ecology (IE) seeks to develop sustainable systems for provision of important needs in modern society. The field encompasses evaluation of the sustainability of currently existing systems, products and processes and 
development of design approaches for more sustainable systems (e.g. Williams et al., 2017). For the first, IE provides a toolbox of methods such as life cycle assessment (LCA), material and energy flow analysis (MFA) and environmental footprint (e.g. Kennedy et al., 2012). For the second, it suggests innovative approaches to system design such as urban metabolism (Kennedy et al., 2007; Wolman, 1965), product life cycles and closed-loop systems, e.g. industrial symbiosis (Ehrenfeld and Gertler, 1997). Many of those approaches can be useful for the design of urban infrastructures (e.g. Hodson et al., 2012; Pandis Iveroth, 2014). However, it has been claimed that IE is not primarily concerned with processes of change that can lead to implementation of these innovative system designs (Rotmans and Loorbach, 2009), and pays little attention to the societal embeddedness of industrial systems and, more generally, is lacking theory of agency (Andrews, 2000; Green and Randles, 2006). Furthermore, IE has been criticised for system optimisation approaches and the a lack of focus on system innovations (e.g. Mulder, 2007).

In work to overcome these shortcomings in the IE field, the importance of applying a social perspective and system innovation approaches and exploring the socio-technical dynamics of system change have been recognised (e.g. Breetz, 2017; Fischer-Kowalski and Rotmans, 2009; Williams et al., 2017). In line with this, an emerging subfield of political IE has been proposed to embrace integrative, complementary and critical approaches to connecting politics and IE (Breetz, 2017). Furthermore, backcasting has been suggested as a complementary approach to IE that can enable development of flexible technological strategies towards system innovations (Mulder, 2007). At the same time, when experimenting with IE and participatory backcasting, Giurco et al. (2011) conclude that IE introduces an "inherently normative component" into the PB process, which can limit the space of alternatives considered. This thesis advances an ongoing line of research on PB to address a need in approaches to guide sustainability transitions of infrastructure systems. 


\section{Research design and methods}

\subsection{Transdisciplinary research design}

Transdisciplinary research (TdR) assumes involvement of actors outside academia in a research process, in order to integrate best available knowledge, increase reflexivity and create ownership of problems and solution options (Lang et al., 2012). The ultimate aim of TdR is to deliver both scientific and societal outcomes. Benefits of TdR are particularly recognised for studies dealing with sustainability challenges, which often involve complex societal issues that could influence a large number of actors (e.g. Kirby, 2019; Wamsler, 2017). Moreover, industrial ecology scholars have pointed out a need in multiple ontologies to adequately address complex adaptive systems (Allenby, 2006), which TdR has the potential to enable (Brandt et al., 2013; Lang et al., 2012). Designing a TdR study commonly includes three phases: 1) collaborative problem framing and building a collaborative research team; 2) co-creation of solution-oriented and transferable knowledge through collaborative research; and 3) (re-)integrating and applying the co-created knowledge (Lang et al., 2012).

Due to its potential to concurrently solve a societal problem and explore scientific questions, TdR was considered well-suited to the aim of this thesis and was applied following phases 1-3 listed above. This allowed for testing and refinement of the framework developed for strategic planning in the real-life contexts of two cities (Bila Tserkva, Ukraine, and Niš, Serbia), which would not be possible using more conventional research approaches.

Research methods applied within the TdR strategy in this thesis work included single and multiple case studies. Overall, the work was based upon three cases:

- Case I. Sustainable heating and cooling system in Bila Tserkva, Ukraine, by 2050

- Case II. Sustainable heating and cooling system in Niš, Serbia, by 2050

- Case III. Changing practice of strategic regional planning in Sweden.

For the development of an adaptable planning framework, the principles of modularity (Baldwin and Clark, 2000), participatory modelling (Voinov et al., 2016) and transdisciplinarity (Lang et al., 2012) were applied 
(Objective 1). Sections 3.2 and 3.3 outline the justification for selecting these approaches for the framework design (for more details, see Paper I). Overall, the modular participatory backcasting (mPB) framework was developed through the course of interlinked theoretical and empirical research (Figure 3).

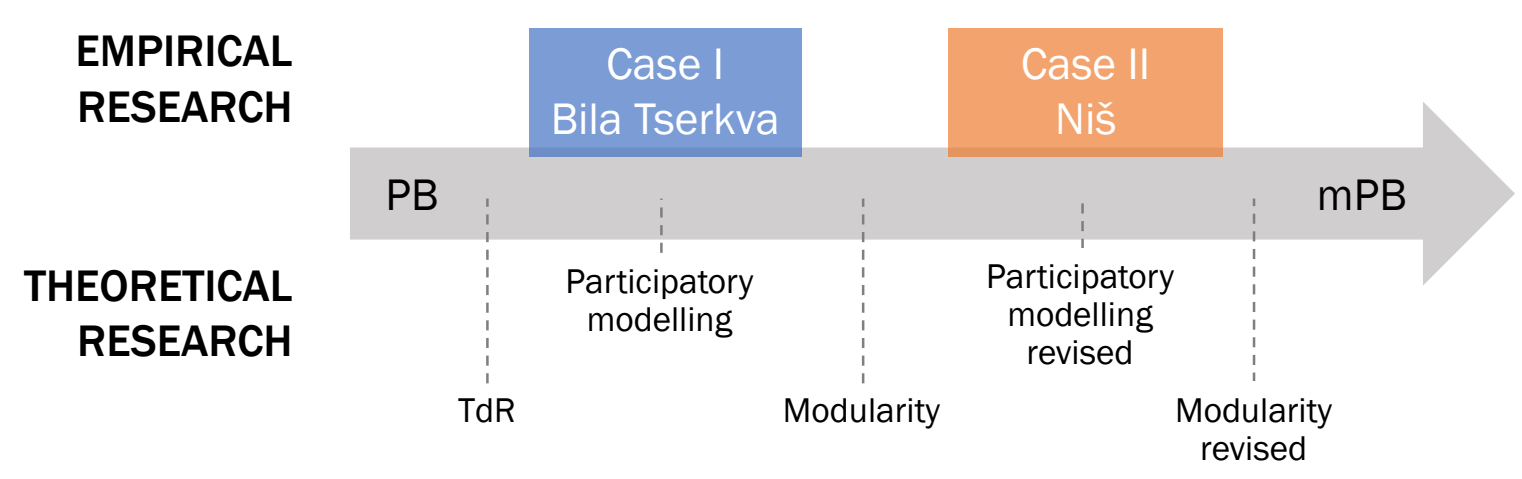

Figure 3: Approach to the development of the modular participatory backcasting (mPB) framework in this thesis, which included empirical research in two cases and theoretical research. $\mathrm{PB}=$ participatory backcasting, $\mathrm{TdR}=$ transdisciplinary research.

A method for scenario development and selection (Objective 2) was designed based on a conceptual modelling approach, morphological analysis (Ritchey, 2018; Zwicky, 1969). The method was then refined in the course of two PB processes, Case I and Case II. See Section 3.3.3 and Paper II for the justification for basing the scenario development method upon the morphological analysis. To strengthen scenario analysis within PB-based planning processes (Objective 2), quantitative modelling of urban energy system in the LEAP software (Heaps, 2014) was implemented in Case II. See Section 3.3.4 and Paper III for the relevance of LEAP for this purpose. To allow for efficient co-informing between these two approaches (i.e. the scenario development method and the approach to scenario analysis based on LEAP modelling) and participatory processes, principles of participatory modelling (Voinov et al., 2016) and transdisciplinarity (Lang et al., 2012) were applied. See Section 3.3 on the suitability of PM and Td principles for this purpose.

Objective 3 was addressed through semi-structured interviews and participatory observations implemented within a single case study, Case III. An overview of the different types of methods used in this thesis is presented in Table 1. 
Table 1: Research methods used to address the thesis objectives, the cases studied and the paper/s in which they are described

\begin{tabular}{|c|c|c|c|}
\hline Objectives & Research methods & Cases & Papers \\
\hline \multicolumn{4}{|l|}{ Objective 1} \\
\hline $\begin{array}{l}\text { Develop a strategic planning } \\
\text { framework for the heating and } \\
\text { cooling sector based on } \\
\text { participatory backcasting and } \\
\text { examine its adaptability to a local } \\
\text { context }\end{array}$ & $\begin{array}{l}\text { Multiple case study } \\
\text { Participatory backcasting } \\
\text { Modularisation, participatory } \\
\text { modelling } \\
\text { Co-creation workshops }\end{array}$ & $\begin{array}{l}\text { Case I: Bila } \\
\text { Tserkva, Ukraine } \\
\text { Case II: Niš, Serbia }\end{array}$ & Paper I \\
\hline \multicolumn{4}{|l|}{ Objective 2} \\
\hline $\begin{array}{l}\text { Develop methods for scenario } \\
\text { development, selection and } \\
\text { analysis to allow for co-informing } \\
\text { between modelling and } \\
\text { participatory processes within } \\
\text { PB-based strategic planning }\end{array}$ & $\begin{array}{l}\text { Multiple case study } \\
\text { Participatory backcasting } \\
\text { Participatory modelling } \\
\text { LEAP modelling } \\
\text { Morphological analysis } \\
\text { Co-creation workshops }\end{array}$ & $\begin{array}{l}\text { Case I: Bila } \\
\text { Tserkva, Ukraine } \\
\text { Case II: Niš, Serbia }\end{array}$ & $\begin{array}{l}\text { Paper II, } \\
\text { Paper III }\end{array}$ \\
\hline \multicolumn{4}{|l|}{ Objective 3} \\
\hline $\begin{array}{l}\text { Identify factors that could } \\
\text { influence social scales of the } \\
\text { impact of participatory strategic } \\
\text { planning processes }\end{array}$ & $\begin{array}{l}\text { Single case study } \\
\text { Semi-structured interviews } \\
\text { Participatory observations } \\
\text { Qualitative content analysis }\end{array}$ & $\begin{array}{l}\text { Case III: Swedish } \\
\text { regions }\end{array}$ & Paper IV \\
\hline
\end{tabular}

\subsection{Case studies}

The case study as a research method allows a contemporary phenomenon to be investigated in depth and within its real-life context, especially when the boundaries between phenomenon and context are not clearly evident (e.g. Yin, 2012). The case study can be of different designs, including single and multiple, embedded and holistic (Yin, 2011). While the case study approach does not allow for statistical generalisation, it can lead to analytical generalisation (e.g. Mills et al., 2010).

In this thesis, multiple case studies based on Case I and Case II served to provide an empirical basis for the development and refinement of an adaptable PB-based planning framework (Objective 1) and methods for scenario development, selection and analysis based on co-informing between participatory processes and conceptual and quantitative modelling (Objective 2). A single case study based on Case III was applied to thoroughly explore factors that could influence the impact of a participatory strategic planning process on organisational changes (Objective 3). Cases I-III and reasons for their inclusion in the research are briefly described in the following subsections (Section 4.2.1-4.2.3). 
4.2.1 Case I: Sustainable heating and cooling system in Bila Tserkva, Ukraine, by 2050

Case I was included in this thesis work because a number of its specific features enabled a novel planning framework to be tested and refined in the context of a real-life planning process. The city council of Bila Tserkva adopted a proactive position regarding the development of a municipal strategy in the heating and cooling sector and in January 2012 approached researchers later involved in this case study with an offer to experiment with a novel framework for strategic planning. The city council representatives were open to the idea of participatory approaches to planning and expressed willingness to support the involvement of a broad range of stakeholders from the city.

Case I was included in this thesis as a part of an overarching transdisciplinary research strategy. Key characteristics of the case are summarised in Table 2.

Table 2: Summary of Case I: Sustainable heating and cooling system in Bila Tserkva, Ukraine, by 2050

Period of implementation

Research objectives addressed

Societal problems addressed

\section{Stakeholders involved}

\section{January 2012 - May 2013}

Objective 1, Objective 2

Development of a vision, a pathway and an action plan towards a more sustainable heating and cooling system in the city by 2050 . Capacity building for local stakeholders regarding novel methods of strategic planning.
- City Council;
- Department of Urban Planning and Architecture;
- Housing and Communal Unit of the City Council;
- public DH company;
- private company - owner of $\mathrm{CHP}$ and part of the heat distribution network;
- private company - producer of individual heating equipment;
- representatives of $\mathrm{DH}$ customers;

- three local NGOs dealing with heating issues;

- Ukrainian association of engineers of energy-efficient technologies;

- public company managing water issues;

- local media;

- researchers from three Ukrainian research institutions: NTUU KPI, NEVMRU, and IHM of NAS of Ukraine;

- researchers from TU Delft, the Netherlands, and KTH, Sweden.

PB or other long-term planning approaches were not known in the city before the project and planning for urban infrastructure such as the heating and cooling system had never been implemented in a participatory way. Furthermore, the city was lacking resources (both financial and human) to implement such a full-scale strategic planning process. Engagement in the 
project provided the city with an opportunity to address some of these societal problems (see Table 2). The context in the heating and cooling sector in Bila Tserkva is briefly described in Section 2.2; for more details, see Papers I and II. The design of the participatory process developed and implemented in Case I is presented in Figure 4 and the participatory activities performed in Case I are depicted in Figure 5.

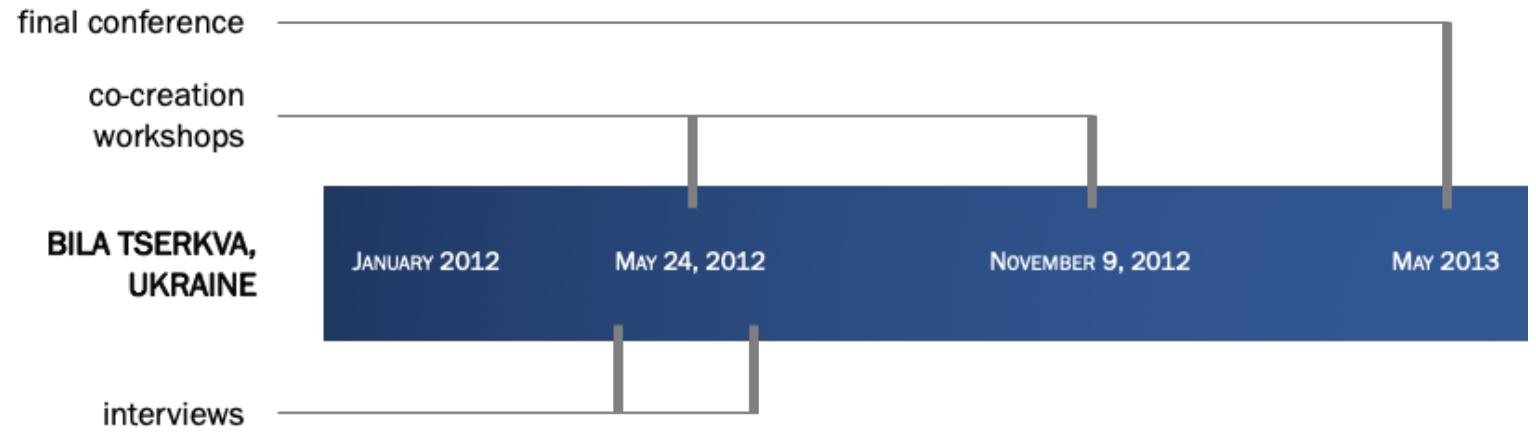

Figure 4: Design of the participatory process in Bila Tserkva (Case I), which included preinterviews, two co-creation workshops and a final conference.

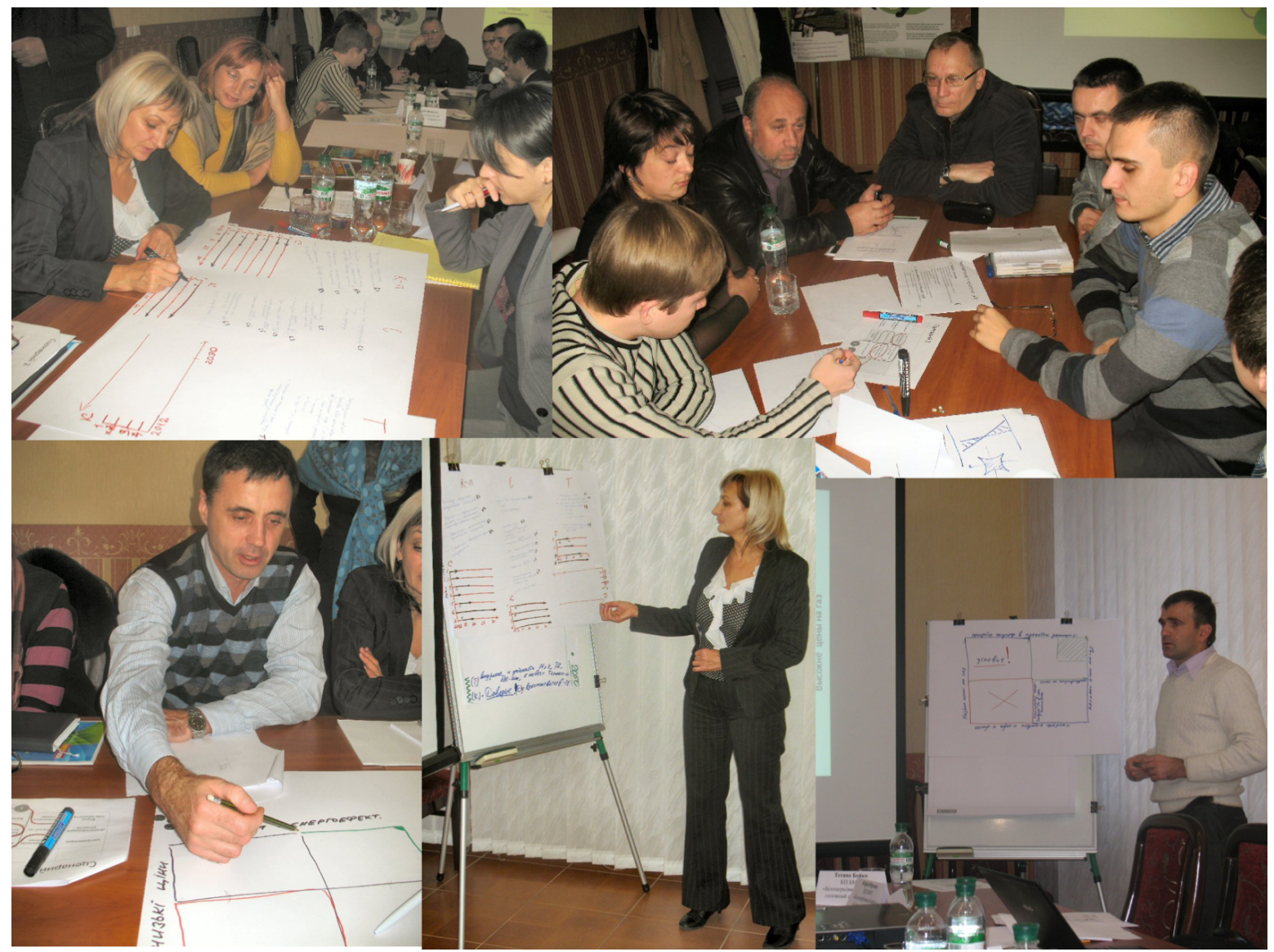

Figure 5: Co-creation work by the stakeholders during participatory activities in Case I. Photo: Valery Oliynik. 
4.2.2 Case II: Sustainable heating and cooling system in Niš, Serbia, by 2050

Similarly to Case I, Case II had a number of features that made it suitable for investigation in this thesis work. For example, the city council of Niš is one of the most active in Serbia regarding the development of sustainability plans (SEAP was adopted in the city in 2014) and was willing to further advance its municipal strategy in the energy field by developing a dedicated strategy for the heating sector. Furthermore, a number of similarities with Case I made Case II a suitable choice for a multiple case study design applied to address Objectives 1 and 2. First, the heating and cooling was of interest to the city. Second, the city did not have experience with any participatory planning approaches or previous experience with $\mathrm{PB}$, and provided a great opportunity to further refine the strategic planning framework developed and applied in Case I. Consequently, Case II was included in this thesis under the TdR strategy (Table 3). Due to the involvement of a local research group with a strong profile in energy system modelling, Case II enabled investigation of coinforming between quantitative modelling and participatory process of strategic planning within Objective 2.

Table 3: Summary of Case II: Sustainable heating and cooling system in Niš, Serbia, by 2050

\begin{tabular}{|c|c|c|}
\hline Period of implementation & \multicolumn{2}{|l|}{ January 2014 - May 2015} \\
\hline $\begin{array}{l}\text { Research objectives } \\
\text { addressed }\end{array}$ & \multicolumn{2}{|l|}{ Objective 1, Objective 2} \\
\hline $\begin{array}{l}\text { Societal problems } \\
\text { addressed }\end{array}$ & \multicolumn{2}{|c|}{$\begin{array}{l}\text { Development of a vision, a pathway and an action plan towards a } \\
\text { more sustainable heating and cooling system in the city by } 2050 \text {. } \\
\text { Capacity building for local stakeholders regarding novel methods of } \\
\text { strategic planning. }\end{array}$} \\
\hline Stakeholders involved & $\begin{array}{l}\text { - City Council for Energy } \\
\text { Efficiency; } \\
\text { - three city municipalities; } \\
\text { - Department for Planning and } \\
\text { Construction; } \\
\text { - Division for Sustainable } \\
\text { Development, Department of } \\
\text { Commerce, Sustainable } \\
\text { Development and } \\
\text { Environmental Protection; } \\
\text { - Energy Division of the city's } \\
\text { Department of Energy; }\end{array}$ & $\begin{array}{l}\text { - private company - producer } \\
\text { of energy equipment; } \\
\text { - private company - natural } \\
\text { gas supplier; } \\
\text { - public DH company; } \\
\text { - NGO of customers of DH; } \\
\text { - representatives of users of } \\
\text { individual heating solutions; } \\
\text { - researchers from two } \\
\text { Serbian universities: } \\
\text { University of Belgrade and } \\
\text { University Kragujevac; } \\
\text { - researchers from KTH, } \\
\text { Sweden. }\end{array}$ \\
\hline
\end{tabular}

Similarly to Case I, the city of Niš did not use long-term planning approaches in its planning practice and recognised a need for developing relevant strategic 
planning capacities among local stakeholders and employees of different departments of the city council. While collaborations between local stakeholders were more advanced than in Bila Tserkva, inter-department collaborations and involvement of a broader range of societal actors (especially end-users) in planning activities were not common in Niš. Being engaged in the case study provided the city with an opportunity to address these issues and develop a strategic plan for its heating sector. The context in the heating and cooling sector in Niš is briefly described in Section 2.2; for more details see Papers I, II and III. The design of the participatory process developed and implemented in Case II is presented in Figure 6 and the participatory activities performed in Case II are depicted in Figure 7.

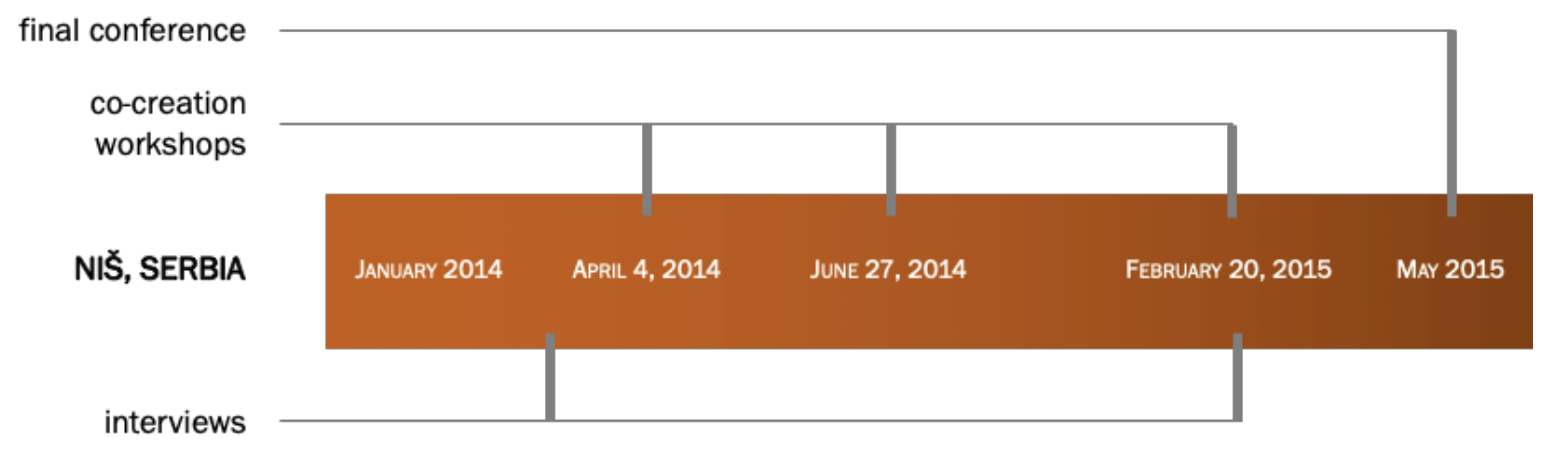

Figure 6: Design of the participatory process in Niš (Case II), which included pre- and postinterviews, three co-creation workshops and a final conference.

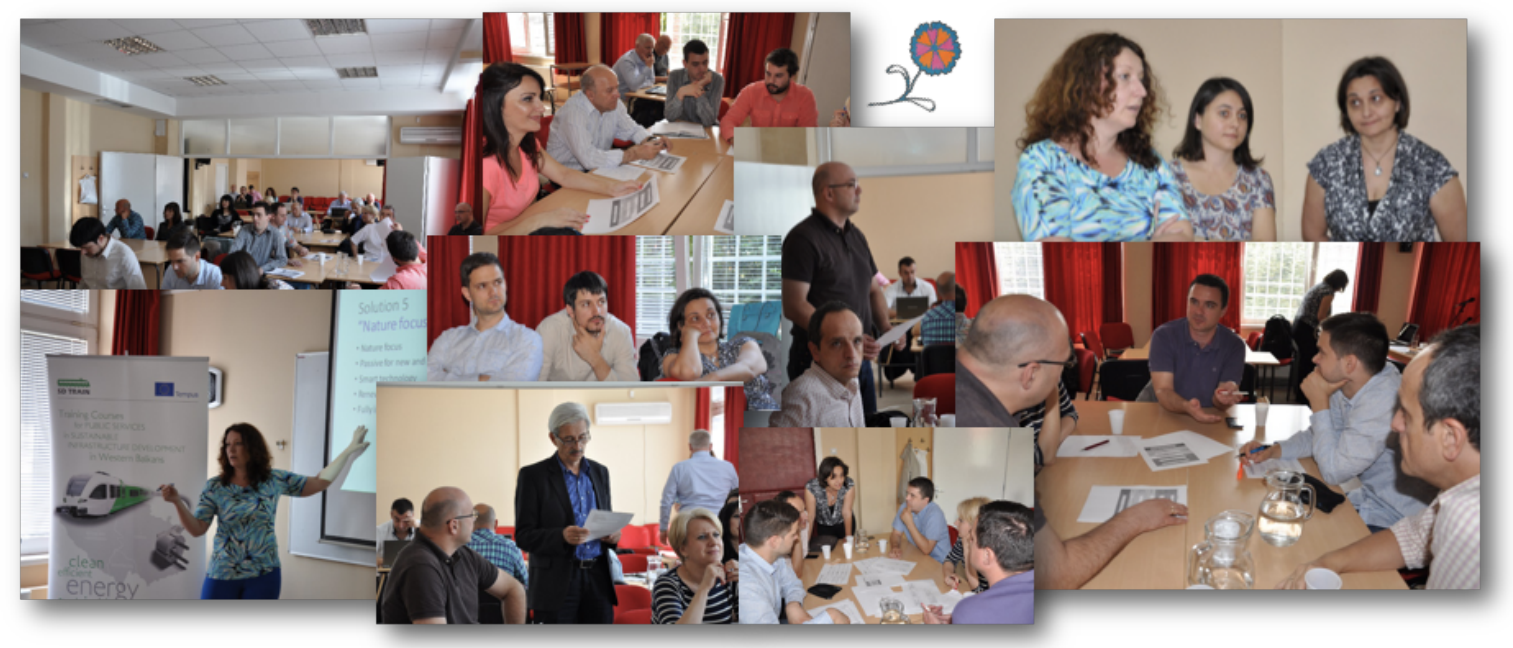

Figure 7: Co-creation work by the stakeholders during participatory activities in Niš (Case II). Photo: Oleksii Pasichnyi. 


\subsubsection{Case III: Changing practice of strategic regional planning in Sweden}

Case III was conducted to address Objective 3, which emerged in the course of research within Case I and Case II, namely to identify factors that could influence the social scales of the impact (e.g. changes in the organisations involved) of participatory strategic planning processes. Case III provided the possibility to explore this objective due to several factors. First, the design of the participatory process in the Region 2050 project, Case III (Figure 8), was in many ways identical to that applied within the PB projects in Case I and Case II and assumed involvement of one or several individual representatives of organisations in a series of participatory activities, organised as co-creation workshops.

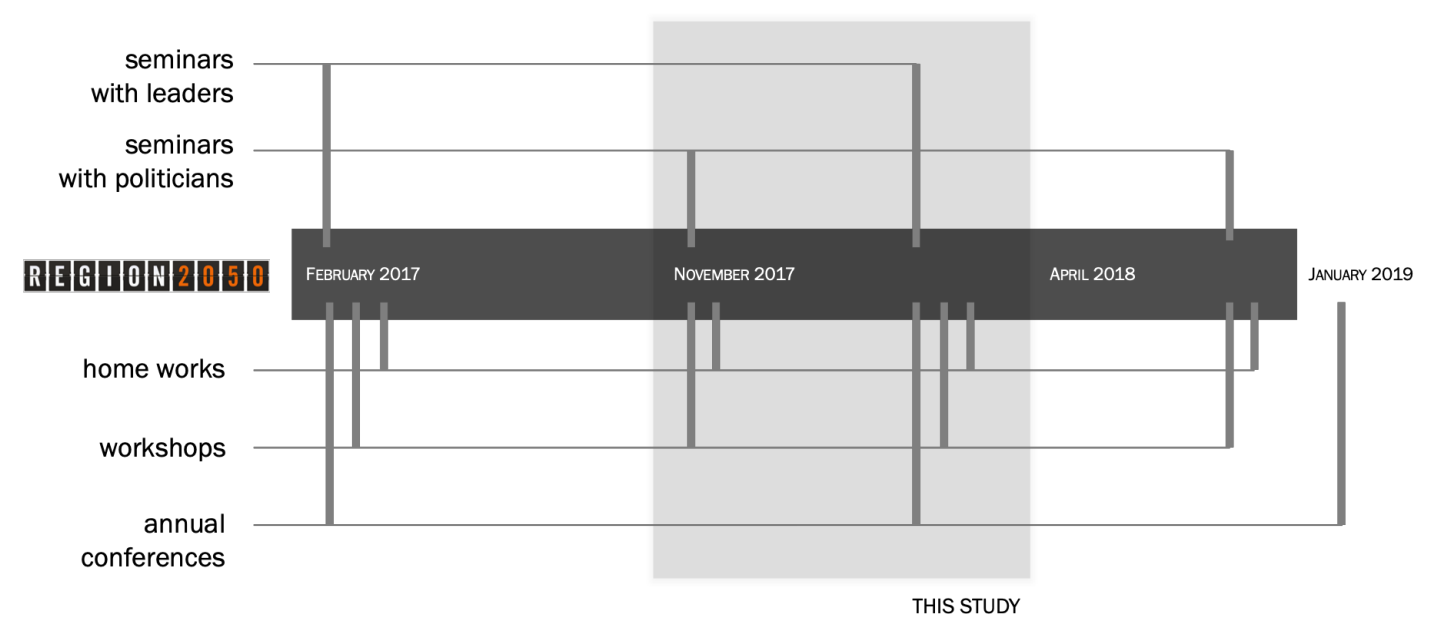

Figure 8: Process design of Region 2050 (Case III) and the timeframe of data collection within this thesis work (adapted from Paper IV).

Second, Case III aimed at advancing regional planning practice in Sweden by integrating future studies methods, including PB (in a different modification than the PB-based framework developed in this thesis) and scenario planning. Finally, Case III provided an opportunity for in-depth analysis of interlinks between the participatory process and responses of the organisations involved, by means of individual semi-structured interviews with selected participants and participatory observations during the co-creation workshops. A TdR strategy was not applied in Case III, even though the case itself aimed at solving societal problems such as supporting the elaboration of regional development plans (Regional Utvecklingsstrategi, RUS) in Swedish regions and capacity building of representatives of regional authorities. A short overview of Case III is presented in Table 4. 
Table 4: Summary of Case III: Changing practice of strategic regional planning in Sweden

\begin{tabular}{|c|c|c|}
\hline $\begin{array}{l}\text { Period of involvement and } \\
\text { data collection }\end{array}$ & November 2017-October 2018 & \\
\hline $\begin{array}{l}\text { Research objectives } \\
\text { addressed }\end{array}$ & Objective 3 & \\
\hline Stakeholders involved & $\begin{array}{l}\text { - Representatives of } \\
21 \text { Swedish regions; } \\
\text { - Reglab; } \\
\text { - the Swedish Agency for } \\
\text { Economic and Regional } \\
\text { Growth; }\end{array}$ & $\begin{array}{l}\text { - Vinnova, the Swedish } \\
\text { governmental agency for } \\
\text { innovation; } \\
\text { - consultancies supporting } \\
\text { design and implementation of } \\
\text { the process. }\end{array}$ \\
\hline $\begin{array}{l}\text { Participatory activities } \\
\text { examined in this thesis } \\
\text { work }\end{array}$ & $\begin{array}{l}2^{\text {nd }} \text { co-creation workshop } \\
\text { Annual Reglab conference } \\
3^{\text {rd }} \text { co-creation workshop }\end{array}$ & \\
\hline
\end{tabular}

Case III, similarly to Case I and Case II, deals with the public sector, Swedish regional authorities that are responsible for infrastructural development on the regional level and for economic and cultural development in the regions. A distinctive characteristic of Case III is a rather well-developed participatory culture in Swedish regions; typically, a broad range of regional actors is involved in planning processes by means of consultations and various forms of collaboration. However, long-term planning (for 20-50 years ahead) is not commonly used and poorly known (Reglab, 2017). This situation impedes the possibility to prepare for uncertain conditions in the future due to e.g. climate change, geopolitical instability, rapid demographic changes and so on. Furthermore, planning practice in the regions often struggles from a singlesector perspective and lack of agile planning approaches. A need for developing new capacities regarding strategic planning was recognised by the regional authorities themselves, leading to the initiation of the Region 2050 project (Reglab, 2017). A possibility to learn about factors that could enable incorporation of the new methods and tools into the planning practices used by the regional authorities was seen as beneficial by the Region 2050 team and was an important reason for inclusion of this case study in the thesis work.

\subsection{In-depth interviews}

In-depth research interviews allow for investigation of personal perceptions and opinions of individuals regarding particular topics or issues, in interviews, knowledge evolves through dialogue (Kvale, 2008). The design of research interviews can differ in dimensions such as structure (the extent to which an interview is guided by questions), openness of purpose (approach to revealing the purpose of an interview to an interviewee), exploration versus hypothesis 
testing, description versus interpretation, and finally an intellectualemotional dimension (Kvale, 2008). The semi-structured format of interviews combines structured questions with unstructured questions and is useful when working with complex issues, due to a possibility to ask spontaneous questions, deepen understanding and clarify answers to questions (Wilson, 2013).

In this thesis, a semi-structured format of interviews that allowed rich and indepth data to be collected was selected to investigate Objective 3. For more details on the use of interviews in the research design, see Paper IV.

\subsection{Participatory observations}

Observation is a method of data collection in which researchers observe behaviours and meaning as they emerge in their natural setting (Berg, 2001). Participatory observations involve the observer being a member of the setting in which they are collecting data. This method provides an understanding of a context within which people interact and offers a possibility to study things that people may be unwilling to discuss in an interview. An observation protocol in the form of field notes is a commonly used approach for data collection, but it is important to make field notes in an unobtrusive way (McKechnie, 2008).

In this thesis, observation protocols were developed for data collection within each of the three cases. For Case I and Case II, several observation protocols were developed for each co-creation workshop, including observations of the overall processes and of smaller working groups formed during the workshops. Within Case III, observation protocols from two events with different formats in Region 2050 were developed, with two observers for each event. Similarly to the interviews, these observation protocols were analysed using the qualitative content analysis (Kuckartz, 2014) supported by MAXQDA software (see Paper IV for more details). 


\section{Results and discussion}

\subsection{Modular participatory backcasting (mPB): A strategic planning framework for the heating and cooling sector (Paper I)}

Investigation of Objective 1 resulted in the development of a novel framework, modular participatory backcasting (mPB), for strategic planning in the heating and cooling sector. The mPB framework was developed by applying the principles of modularity to the five-step participatory backcasting approach described by Quist (2007). The requirements of a planning framework in the heating and cooling sector, based on insights from transition studies (see Section 3.1) were considered during its development. Identified specificities of the heating and cooling sector (e.g. local contextualisation of the sector that implies a need to explicitly address system boundaries) were also considered. In the context of the framework design, the concept of module suggested by Baldwin et al. (2014) was interpreted as a unit of the framework, characterised by interdependence of decisions within it and relative independence of decisions between modules. Consequently, the initial 5-step approach was split into 13 modules. Table 5 presents the architecture of the framework, describing each module in terms of its goals/outputs, inputs and examples of methods to be used within this module.

The content of the modules delineated for mPB (Table 5) was defined to ensure action-orientation of the framework and its performance as a strategic planning approach. First, inclusion of modules such as Action plan and Follow-ups was deemed crucial, along with elaboration of the Current situation module to connect the desirable future vision to a starting point for system change. Second, robustness testing (e.g. analysis of the performance under different external scenarios) of suggested solutions for system reconfiguration was seen as important for development of more robust solutions and consequently was included in the Drivers and Solution testing modules. Similar steps can be found in other PB projects aimed at development of robust strategies (e.g. Ashina et al., 2012; Kanter et al., 2016; Van der Voorn et al., 2012). Inclusion of the system boundaries module confirmed to be important for cross-sectorial planning and enabling analysis of current and future connections between the heating and 
Table 5: Description of the 13 modules in the modular participatory backcasting (mPB) framework (adapted from Paper I)

\begin{tabular}{|c|c|c|c|}
\hline Module & Goal/Outputs & $\begin{array}{l}\text { Input } \\
\text { (modules) }\end{array}$ & Examples of methods \\
\hline $\begin{array}{l}\text { Problem orientation } \\
\text { (PO) }\end{array}$ & $\begin{array}{l}\text { Formulation and specification } \\
\text { of a problem to be addressed; } \\
\text { identification of key challenges }\end{array}$ & - & $\begin{array}{l}\text { Analysis of trends, } \\
\text { sustainability assessment of } \\
\text { current solutions }\end{array}$ \\
\hline $\begin{array}{l}\text { System boundaries } \\
\text { (SB) }\end{array}$ & $\begin{array}{l}\text { Description of various } \\
\text { boundaries of a socio-technical } \\
\text { system behind the formulated } \\
\text { problem (e.g. spatial, time, } \\
\text { socio-political) }\end{array}$ & $\mathrm{PO}$ & $\begin{array}{l}\text { Process-based description of } \\
\text { a system; life cycle approach }\end{array}$ \\
\hline $\begin{array}{l}\text { Current situation } \\
\text { (CS) }\end{array}$ & $\begin{array}{l}\text { Analysis of the current state of } \\
\text { a socio-technical system }\end{array}$ & $\mathrm{PO}, \mathrm{SB}$ & $\begin{array}{l}\text { Descriptive statistics; } \\
\text { causal-loop diagrams, LCA }\end{array}$ \\
\hline $\begin{array}{l}\text { Stakeholder analysis } \\
\text { (SA) }\end{array}$ & $\begin{array}{l}\text { Definition of actors who can } \\
\text { affect, or be affected by, the } \\
\text { problem }\end{array}$ & $\mathrm{PO}, \mathrm{SB}$ & $\begin{array}{l}\text { Power-impact analysis, } \\
\text { analysis of actor roles, } \\
\text { constellation analysis }\end{array}$ \\
\hline $\begin{array}{l}\text { Needs and functions } \\
\text { (NF) }\end{array}$ & $\begin{array}{l}\text { Exploration of current and } \\
\text { future system functions and } \\
\text { societal needs to be fulfilled }\end{array}$ & PO, SA & Why? questions technique \\
\hline Vision (V) & $\begin{array}{l}\text { Creation of a desirable future } \\
\text { vision }\end{array}$ & $\mathrm{PO}, \mathrm{NF}, \mathrm{SA}$ & Storytelling, brainstorming \\
\hline Criteria (C) & $\begin{array}{l}\text { Definitions and quantification of } \\
\text { criteria that specify the vision }\end{array}$ & V & $\begin{array}{l}\text { Brainstorming, } \\
\text { quantification }\end{array}$ \\
\hline Solutions (S) & $\begin{array}{l}\text { Generation of a complete } \\
\text { solution space }\end{array}$ & $\mathrm{V}, \mathrm{SB}$ & $\begin{array}{l}\text { Storytelling, morphological } \\
\text { method }\end{array}$ \\
\hline Drivers $(D)$ & $\begin{array}{l}\text { Identification of external forces } \\
\text { that could impact the system; } \\
\text { identification of trends and key } \\
\text { uncertainties }\end{array}$ & SB & $\begin{array}{l}\text { Brainstorming, uncertainty- } \\
\text { impact analysis, modelling }\end{array}$ \\
\hline Solution testing (ST) & $\begin{array}{l}\text { Selection of a solution for } \\
\text { implementation }\end{array}$ & S, C, D & $\begin{array}{l}\text { Criteria testing, } \\
\text { robustness/sensitivity } \\
\text { testing; sustainability testing; } \\
\text { modelling }\end{array}$ \\
\hline Pathway (P) & $\begin{array}{l}\text { Elaboration of a set of changes } \\
\text { that are required in order to } \\
\text { achieve the desirable future } \\
\text { vision by means of the chosen } \\
\text { solution }\end{array}$ & $\begin{array}{l}\mathrm{CS}, \mathrm{SA}, \mathrm{ST} \\
\mathrm{V}\end{array}$ & Brainstorming, modelling \\
\hline Action plan (AP) & $\begin{array}{l}\text { Short-term action plan in line } \\
\text { with the designed pathway }\end{array}$ & $\mathrm{CS}, \mathrm{SA}, \mathrm{P}$ & $\begin{array}{l}\text { Project management } \\
\text { techniques }\end{array}$ \\
\hline Follow-ups (F) & $\begin{array}{l}\text { Design of follow-up activities } \\
\text { and initial monitoring of } \\
\text { implementation of the project } \\
\text { outcomes }\end{array}$ & $P, A P$ & $\begin{array}{l}\text { Brainstorming; } \\
\text { follow-up interviews }\end{array}$ \\
\hline
\end{tabular}


cooling sector and components such as electricity, water, and waste management in the context of both case projects. Moreover, within the system boundaries module, a process-based description of the heating and cooling system was developed (for details, see Paper I). See Paper I for a more detailed description of the content of modules included in $\mathrm{mPB}$.

Empirical validation of $\mathrm{mPB}$ in two participatory strategic planning processes (Case I and Case II) helped refine its design and allowed for investigation of its adaptability to local contexts. The order of the modules is not fixed and iterative implementation of the modules is seen as a relevant practice for an mPB-based process. However, some modules provide inputs to others and should therefore be implemented earlier in the process. Figure 9 shows the interface of $\mathrm{mPB}$, depicting the interconnections between modules as observed in Case I and Case II.

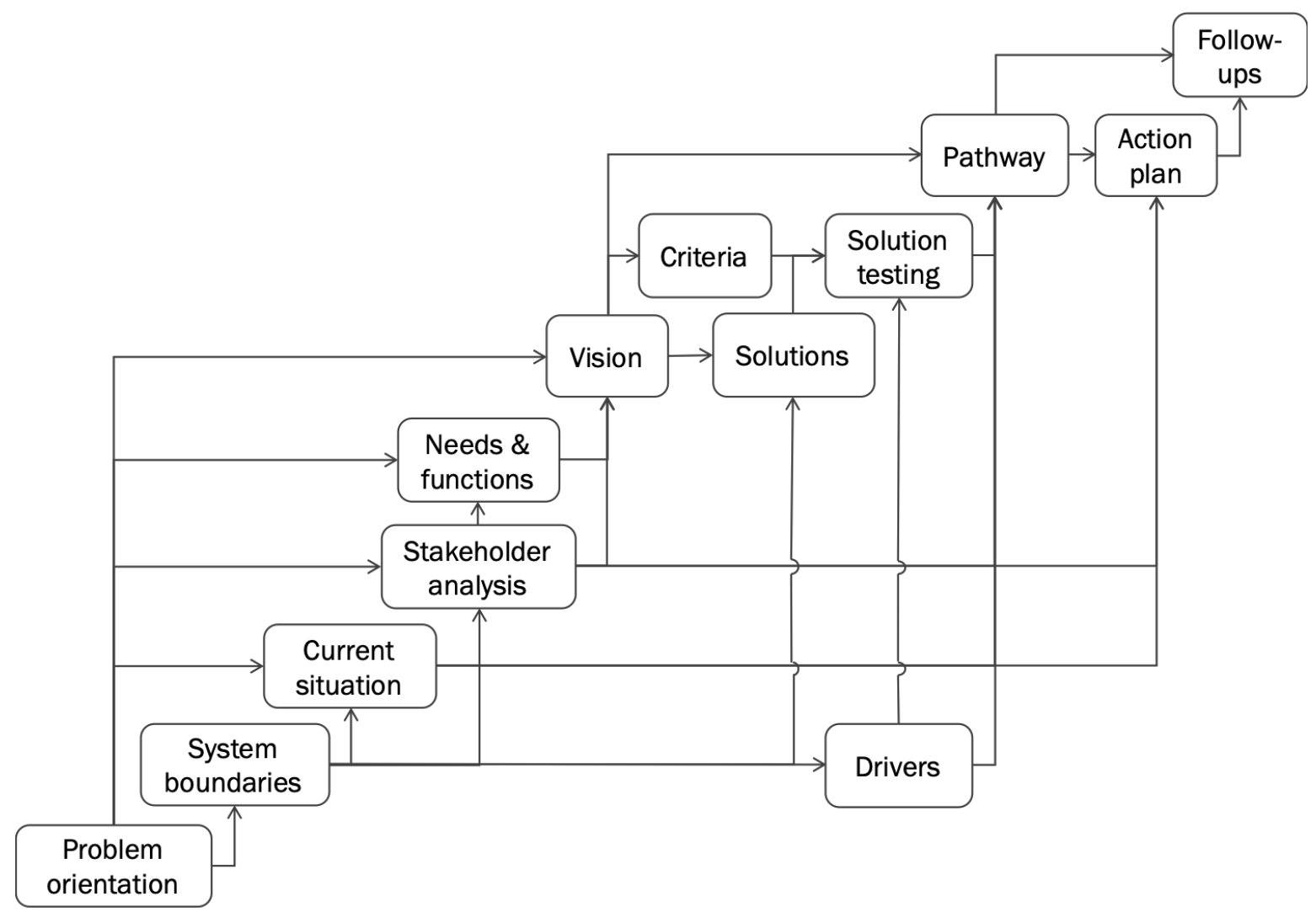

Figure 9: Interconnections between 13 modules of the modular participatory backcasting (mPB) framework as observed in Cases I and II (adapted from Paper I).

When tested in Case I and Case II, the 13 modules of mPB were implemented in a participatory way following the principles of PM (e.g. Voinov et al., 2016) and Td (e.g. Lang et al., 2012). Those two principles were included as standards for the framework, implying that each module has to be applied in 
a participatory way. The designs of the participatory processes in Case I and Case II are presented on Figure 4 and Figure 6, respectively.

Implementation of $\mathrm{mPB}$ according to the principles of $\mathrm{PM}$ and $\mathrm{Td}$ led in both cases to increased transparency in the planning process in comparison with the commonly applied planning activities in these cities. Other positive outcomes included improved capacities relevant for strategic planning (e.g. long-term and system thinking) among the local researchers and other actors involved, and considerable prolongation of the planning horizon compared with that typically used in both cities. Social learning, including improved understanding of the heating and cooling sector by the participants involved and increased knowledge about other sector stakeholders, was observed in both Case I and Case II. This is an outcome previously reported for PB processes (e.g. Brown and Vergragt, 2008; Robinson, 2003).

The mPB framework demonstrated acceptable adaptability in the course of its implementation in Case I and Case II through the modular design. For example, the 13 modules of $\mathrm{mPB}$ were adapted by dimensions such as labour effort dedicated to implementation of each module and ratio of participatory process to back-office work (see Figure 2 and Figure 3 in Paper I) to address project limitations in terms of available time, resources and skills. Furthermore, the order of module implementation in each case was determined to address the project limitations, and the interconnections between modules were considered (Figure 9). The mPB framework was also adapted in terms of the methods used within each module. See Paper I for examples of framework adaptations and use of the properties of modularity (i.e. splitting, exclusion, augmentation, substitution, inverting and porting). Flexibility of a planning framework is important for its applicability in the heating and cooling sector, which is characterised by a diversity of current socio-technical configurations (see Section 2.1) often embedded in the context of urban junctions (e.g. Späth and Rohracher, 2015).

The modular design of $\mathrm{mPB}$ was beneficial in reducing ambiguity regarding the steps and content of the framework in Cases I and II. Reducing the ambiguity is considered to be important for improved transferability of a planning framework to novel contexts (e.g. Heiskanen et al., 2009). This was confirmed by the observed adoption and acceptance of the framework by the stakeholders involved in Cases I and II.

Overall, implementation of mPB in Cases I and II resulted in a number of positive outcomes. Similarly to other PB studies (e.g. Carlsson-Kanyama et al., 2008; Doyle and Davies, 2013; Soria-lara and Banister, 2017), the PB 
processes in Case I and Case II enabled engagement of a broad range of stakeholders in the planning processes (see Table 2 and Table 3 for a list of stakeholders involved in Case I and Case II respectively). They also allowed consensus to be achieved among different actors regarding the main outcomes of the processes (see Table 6 and Table 7 for some of the main process outcomes for Case I and Case II, respectively).

Table 6: Example of results of modular participatory backcasting (mPB) implementation in Bila Tserkva, Ukraine.

$\begin{array}{ll}\text { Vision } & \begin{array}{l}\text { Comfortable indoor climate in residential and public sector buildings } \\ \text { Criteria }\end{array} \\ \text { Final solution } & \text { reliability } \\ & \begin{array}{l}\text { Fully centralised DH that can supply multi-storey buildings and } \\ \text { densely populated areas. DH to be based on natural gas and } \\ \text { renewables (heat pump in wastewater was discussed as a possible } \\ \text { solution, along with a waste incineration plant). Private ownership of } \\ \text { DH and distribution network, with city council influence. } \\ \text { For the private sector and single-family houses, decentralised } \\ \text { renewable-based heating solutions are suggested. }\end{array} \\ & \begin{array}{l}\text { Prices of energy resources } \\ \text { Key uncertainties }\end{array} \\ & \text { Priority of energy efficiency in national energy policy }\end{array}$

Table 7: Example of results of modular participatory backcasting (mPB) implementation in Niš, Serbia.

Vision

Criteria

Final solution

Key uncertainties
Affordable, comfortable and environmentally friendly heating and cooling in Niš by 2050

Affordability; comfort/convenience; energy efficiency; environmental performance; energy security

Final solution named "Efficiency for the green future". It includes setting higher standards on energy efficiency of buildings (class $B$ for new and class $C$ for retrofitted). Maximal expansion of $\mathrm{DH}$ in the centre of the city and zones with high heat load density, and marginal expansion of $\mathrm{DH}$ in zones with low heat load density. The scenario assumes a major increase in the share of renewables for both $\mathrm{DH}$ and decentralised solutions. It also gives priority to green architecture solutions for new buildings in the city (e.g. green walls, biodegradable materials, building placement etc.). Furthermore, the scenario includes the application of smart technologies (e.g. meters, sensors, loT) in new buildings.

Economic development

Political will for change in the energy sector at national level 
To sum up, the mPB approach developed in this thesis can be seen as potentially suitable for strategic planning in the heating and cooling sector framework due to its modular design, content of the modules, and inclusion of PM and Td principles as standards for its implementation. However, the findings regarding the performance and adaptability of $\mathrm{mPB}$ are limited by the possibility to investigate only short-term and mainly tangible outcomes of strategic planning processes in Case I and Case II. A longitudinal study would be needed to consider long-term effects of $\mathrm{mPB}$ in analysis of its adaptability. However, challenges pertaining to the evaluation of the long-term impacts of PB process have previously been identified in the literature (e.g. Quist 2007), and need to be considered in longitudinal study design.

Another set of limitations is posed by the specific context in which mPB was tested and its adaptability was addressed in this thesis, namely post-socialist countries in Eastern Europe. While the mPB process for strategic planning implemented in the cases led to social learning among the participants involved, it also indicated a lack of important capacities to run this type of planning process in the case cities. A need for capacity building and increasing awareness of local actors about the challenges and possible solutions towards sustainability transitions in the heating and cooling sector was identified as an enabler of wider use of mPB in these countries. Similarly, lack of relevant capacities has been identified in previous studies as one of the socio-political and cultural barriers to sustainability transitions in the energy sectors of Ukraine and Serbia (e.g. Lankina et al., 2017; Tešić et al., 2011; Vujic et al., 2017). Development of such capacities among local actors is particularly relevant to avoid misuse of the $\mathrm{MPB}$ approach, for example for manipulation or legitimisation of a particular decision (see Arnstein (1969) for so-called 'ladder of citizen participation').

Finally, evaluation of the impact of mPB processes, such as actions in line with the developed vision and pathway, remains a rather challenging task, similar to impact analysis of PB processes (Neuvonen and Ache, 2017; Quist et al., 2011; Sisto et al., 2016). In this regard, mPB shares many of the limitations of $\mathrm{PB}$ and other participatory planning processes. However, experimentation with the $\mathrm{mPB}$ approach in two cases (Case I and Case II) indicated a direction for broadening the impact of $\mathrm{PB}$ processes beyond individuals directly involved in participatory processes. This resulted in formulation and addressing of Objective 3 in this thesis work (see Section 5.3 for a summary of findings). 


\subsection{Participatory modelling for scenario development, selection and analysis (Papers II and III)}

Work on Objective 2 resulted in the development of a morphological method for scenario development and selection that allows for co-informing between modelling and participatory processes. The morphological method is based on a conceptual modelling approach, morphological analysis (Ritchey, 2018; Zwicky, 1969). Another result achieved for Objective 2 is an approach for scenario analysis based on co-informing between quantitative modelling of urban energy system in LEAP software (Heaps, 2014) and an mPB-based planning process. Co-informing between both types of modelling, conceptual and quantitative, and participatory planning processes was established based on the principles of PM (e.g. Voinov et al., 2016) and Td (e.g. Lang et al., 2012). The morphological method is briefly described and discussed in Section 5.2.1, and the approach for scenario analysis in Section 5.2.2. For more details, see Paper II and Paper III, respectively.

\subsubsection{Morphological method for scenario development and selection (Paper II)}

The morphological method for scenario development and selection includes five steps: 1) identification of system dimensions, 2) identification of 'extreme' states for each dimension, 3) creation of a morphological table and a complete scenario space, 4) exclusion of inconsistent scenarios and 5) selection of scenarios for further in-depth analysis (Figure 10). See Paper II for more detailed description of the morphological method.

The morphological method was developed as a part of the mPB framework to be used for development of internal scenarios (solutions) within its Solutions module. To comply with the standards set for MPB (i.e. PM and Td principles), a number of requirements for implementation of the morphological method were identified from the future studies and scenario planning literature (e.g. Amer et al., 2013; Bryant and Lempert, 2010; Godet, 2006). These requirements include transparency, reliability, coverage, completeness, relevance/density, creativity, interpretability, consistency, differentiation and plausibility of scenario development processes. See Paper II for a description of how these requirements were implemented in Case I and Case II. Similarly, to ensure the transparency of scenario selection processes and allow for selection of a manageable number of scenarios for in-depth analysis within co-creation workshops, a number of scenario selection criteria were added to the method description. These criteria include consistency, desirability, relevance/density, differentiation and plausibility. 
See Paper II for a description of these criteria, the reason for including each of them and examples of how they were applied in Cases I and II.

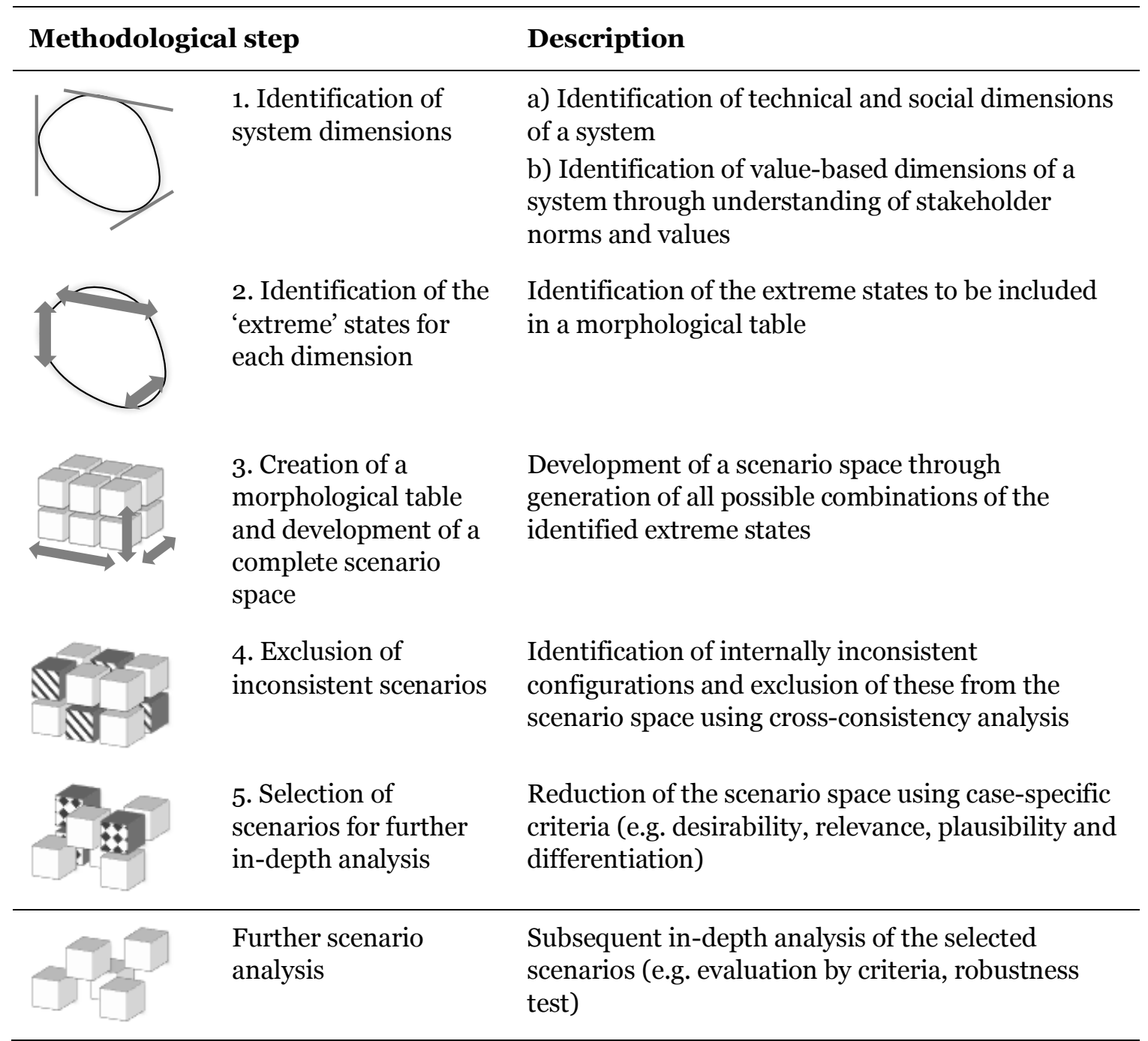

Figure 10: Steps 1 to 5 of the morphological method for scenario development and selection (adapted from Paper II).

While morphological analysis (Zwicky, 1969) has previously been used for scenario development (e.g. Godet, 2006; Ritchey, 2011), it has not been tailored for implementation in a participatory context. Similarly, previous studies have not sought to include socio-technical dimensions in a morphological table. Paper II demonstrates an attempt to tailor morphological analysis for these two purposes.

To allow use of the morphological method as part of mPB in Case I and Case II, its steps were linked with the participatory activities in each case. In Case I, steps 2-4 and partially step 1 were implemented as back-office work by the project team and communicated to the stakeholders involved during the $2^{\text {nd }}$ co-creation workshop (see Figure 4 for the design of participatory process 
in Case I). Steps 1 and 5 were then implemented during the $2^{\text {nd }}$ co-creation workshop. In Case II, step 1 was implemented during the $2^{\text {nd }}$ co-creation workshop and later refined by the project team. Similarly, in Case II steps 2-4 and partially 5 (due to the large number of scenarios) were implemented as back-office work and communicated to the stakeholders during the $3^{\text {rd }}$ cocreation workshop. Step 5 was also finalised in a participatory way during the $3^{\text {rd }}$ co-creation workshop (see Figure 6 for the design of the participatory process in Case II). Consequently, it can be concluded that the morphological methods can be adjusted a particular design of participatory planning process.

Testing of the morphological method in Case I and Case II led to the conclusion that the method helps to at least partially overcome some of the challenges of the intuitive logic approach to scenario development (i.e. reluctance to consider outside-the-box options, groupthink effects and ad-hoc scenario selection (Bryant and Lempert, 2010; Wright et al., 2013)). Hence, the implementation of the morphological method in both cases enabled the development of a rather large space of diverse scenarios (12 scenarios in Case I and 48 scenarios in Case II) based on the dimensions suggested by the stakeholders involved. See Paper II for the examples of morphological tables with the dimensions discerned in Cases I and II. Paper II also illustrates the process of cross-consistency analysis and shows a set of scenarios chosen for in-depth analysis in each of two cases (3 scenarios in Case I and 6 scenarios in Case II). The diversity and creativity of these scenarios were rather high in both cases. The performance of the method was comparable to that reported in other studies using morphological analysis for scenario development (e.g. Godet, 2006; Ritchey, 2011). However, in both Cases I and II, the number of dimensions to be included in the morphological tables was intentionally reduced to allow for comprehension and manageability of the scenario spaces in participatory context. The number of dimensions can be higher if it is possible to use specific software.

To ensure the transparency of the method and proper communication of the steps implemented as back-office work by project teams, high priority has to be given to visualisation and communication of the method's logic, its interim results and final outcomes. In Cases I and II, special visualisation approaches were developed and used for this purpose, as exemplified in Figure 11. This and other examples of the visualisation techniques developed in Cases I and II are described in Paper II. 


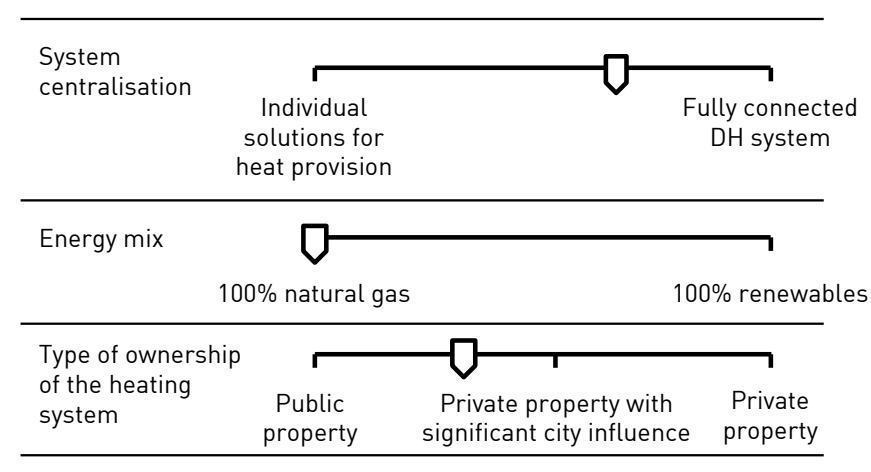

a)

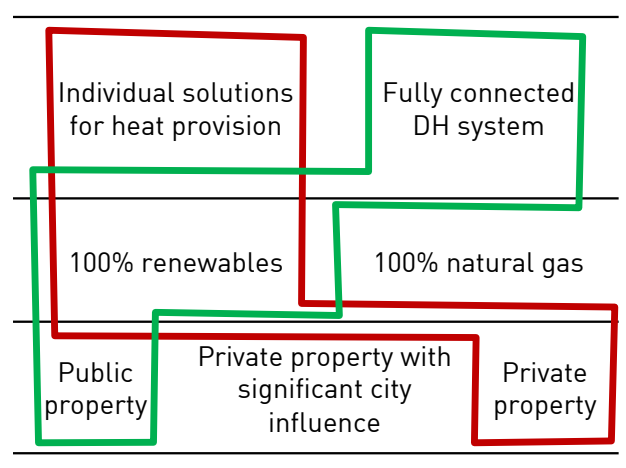

b)

Figure 11: Visualisation of (a) current system configuration and (b) one of the developed scenarios with morphological chart for Case I: Bila Tserkva (reproduced from Paper II).

To sum up, the morphological method for scenario development and selection can be regarded as good practice for scenario development in the context of participatory strategic planning. The potential of the method to generate a wide set of alternative solutions for system reconfiguration is particularly relevant for planning in the heating and cooling sector. This would allow a wide range of alternatives to be explored in a participatory planning process and avoid some being neglected due to e.g. unwillingness of some actors to take them into consideration.

The quality of scenarios developed with the use of the morphological method depends on the quality of socio-technical dimensions identified. Participatory approaches to identification of dimensions, e.g. the storytelling used in Case I and Case II, has the potential to reveal novel and unusual dimensions. For example, in Case II, an aesthetic dimension embracing the idea of installing green walls and roofs, was suggested, which is rather unconventional for planning in the heating and cooling sector. However, such approaches cannot ensure good coverage of all possible dimensions. More systematic methods for identification of system dimensions are needed, to further strengthen the morphological method.

The integration of PM (e.g. Voinov et al., 2016) and Td (e.g. Lang et al., 2012) principles increased the potential of the morphological method to address the limitations of modelling, conceptual modelling in this case, such as hidden assumptions, the risk of simplifications, challenges in uncertainty analysis and ambiguities in model interpretation. The solutions developed were relevant to stakeholders' needs and priorities (similarly to the effects achieved by truly participatory approaches as shown in e.g. Reed et al. (2013)). To further advance scenario development based on co-informing between modelling and participatory processes this study, in line with the findings of 
the previous studies (e.g. Hämäläinen, 2015; Voinov et al., 2016), highlighted a need in addressing the influence of human biases and the risk of groupthink or dominance of one of few individuals in such processes.

\subsubsection{LEAP modelling to support scenario analysis (Paper III)}

To enable scenario analysis within the $\mathrm{mPB}$ process using the benefits of both quantitative modelling (e.g. dealing with system complexity and large number of influencing factors) and participatory methods (e.g. possibility to involve a diversity of perspectives on a system), a participatory modelling approach was developed and implemented in Case II. For this, a quantitative model of the heating system for Case II was created using the Long-range Energy Alternatives Planning System (LEAP) (Heaps, 2014). A conceptual scheme for linking inputs and outputs of the LEAP modelling with inputs and outputs of the $\mathrm{mPB}$ process was developed (Figure 12).

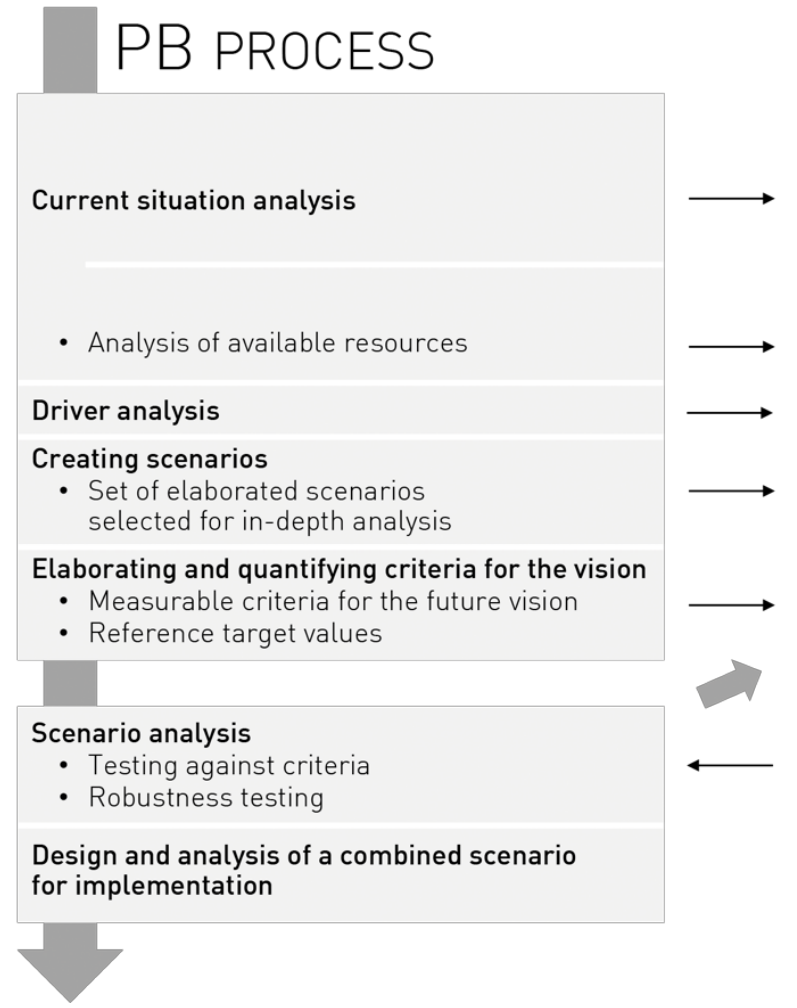

LEAP MODEL

Base year

- Final energy consumption

- Losses

- Exogenous capacities

- Heat production

Key assumptions

- Geothermal and renewable energy potential

MODEL

- General trends

INPUT

- Quantitative parameters obtained from interpretation of qualitative inputs

- List of performance indicators

- Quantitative description of scenarios

- Visualization of scenarios

- Scenario performance: projections for future energy consumption, production, environmental performance

Figure 12: A conceptual scheme for integration of LEAP modelling into a modular participatory backcasting (mPB) process as applied in the case of Niš (Case II) (reproduced from Paper III).

The LEAP model was used to co-inform the participatory process of scenario analysis within the Solution testing module of mPB. However, as in other PM approaches (e.g. Dreyer and Renn, 2011), model development and collection of the data needed were initiated early in the $\mathrm{mPB}$ process. Modules of $\mathrm{mPB}$ 
such as Current situation, Drivers, Criteria and Solution testing were linked with the modelling in LEAP (see Figure 12). See Paper III for a description of the participatory modelling process in Case II and details about integration of the outcomes achieved in participatory activities within the case (see Figure 6 for the design of the participatory process in Case II).

The approach developed facilitated analysis of six scenarios selected in Case II (see Paper III for the description of the selected scenarios). It also helped to analyse the final scenario developed by stakeholders based on the analysis of the six initial scenarios. Hence, performance was estimated and visualisations of some characteristics of the final scenario were created using LEAP modelling (see Figure 13 for an example of the visualisations).

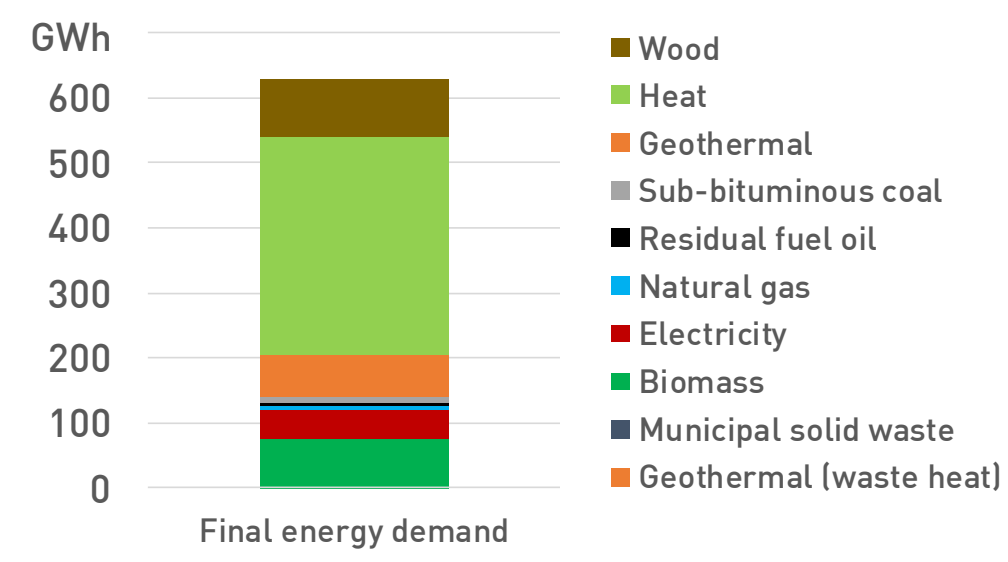

a)

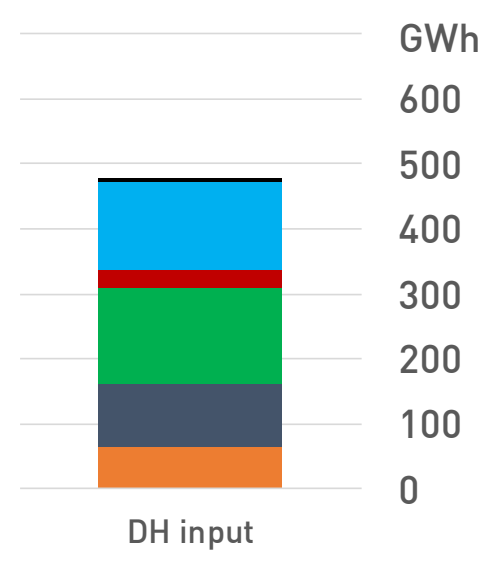

b)

Figure 13: Example of outcomes of participatory modelling using LEAP in Case I: Calculated energy mix for the final combined scenario for Niš in 2030: a) final energy demand and b) input fuels to the district heating (DH) system (reproduced from Paper III).

Similarly to Basco-Carrera et al. (2017), this thesis highlighted a need to distinguish different levels of stakeholder involvement in modelling processes. To ensure a high level of reflexivity in scenario analysis with the use of quantitative modelling in Case II, the principle of PM (Voinov et al., 2016) was supplemented by the principle of Td (Lang et al., 2012). It was observed in Case II that inputs from stakeholders challenged the biases of researchers, and vice versa. A need to clarify and explicitly name all assumptions positively contributed to understanding of the modelling process by all actors involved and facilitated interpretation of modelling outcomes. However, the influence of perceptions and biases was not fully eliminated in the specific case studied. For example, the potential of solar energy in the future energy mix was not included in the model, even though this was suggested during the $\mathrm{mPB}$ process by some of the participants (Paper III). This shows that even more 
research efforts are needed to enable comprehensive and unbiased modelling processes of long-term scenarios.

To sum up, the approach developed allowed for efficient co-informing between the mPB-based strategic planning process and LEAP modelling in Case II (Paper III). Comparison with Case I, in which scenario analysis was implemented in a participatory way, led to the conclusion that the use of quantitative modelling is beneficial for the development of more grounded decisions. However, the challenges and the time required for development and validation of a quantitative model should not be underestimated. While the use of quantitative approaches was identified as crucial for the credibility of planning processes in the socio-cultural contexts of the case cities, the analysis also highlighted a need to develop relevant capacities among local actors that could enable implementation of PM and Td principles in strategic planning processes.

In the course of this thesis work, many similarities in the use of quantitative and conceptual modelling for co-informing $\mathrm{MPB}$ processes were observed. For example, a positive role of the principles of PM and Td for reflexivity and transparency of planning processes was observed for both types of modelling in Case I and Case II. Although the use of conceptual modelling in a participatory context can seem easier than the use of quantitative modelling, this is not always the case. Implementation of the morphological method in Cases I and II demonstrated challenges in communication of the method's logic, such that special visualisation techniques to communicate how it works needed to be developed.

Communication of the interim results and internal logic of the model was also important for the case of LEAP model. For example, a specific task for LEAP modelling was a need to develop a rather large number of assumptions to set the model (Paper III). This could be challenging due to e.g. time limitations in a co-creation workshop. To compensate for developing assumptions outside co-creation workshops and avoid misinterpretation of modelling outcomes, communication of all interim steps and back-office processes to the stakeholders involved was important. Finally, as in the case of conceptual modelling, a need for further research to account for the influence of human biases and a risk of groupthink effects or dominance of one of few individuals in scenario analysis based on co-informing between modelling and participatory processes was identified. 


\subsection{Social scales of the impact of participatory strategic planning processes (Paper IV)}

Work on Objective 3 resulted in identification of three factors that can be used as leverage points to extend the impact of participatory strategic planning processes beyond the individuals directly involved, namely role of individuals as boundary spanners, collaborations between organisations, and institutional plurality in organisations (Paper IV). Identification of these factors was enabled by the development of an integrative heuristic based on concepts from OCMS (e.g. Lozano, 2014, 2008) and IL (e.g. Fuenfschilling and Truffer, 2014; Smink et al., 2015). The heuristic distinguishes a microlevel of individuals, a meso-level of organisations and a macro-level of a broader system in which organisations are located. Relevant concepts from the OCMS and IL fields were allocated by these three levels and their intersections, providing initial insights regarding potential barriers and enablers for extending the impact of participatory strategic planning processes. Figure 14 shows this heuristic as it was used in Case III. For more details about the heuristic and its development, see Paper IV.

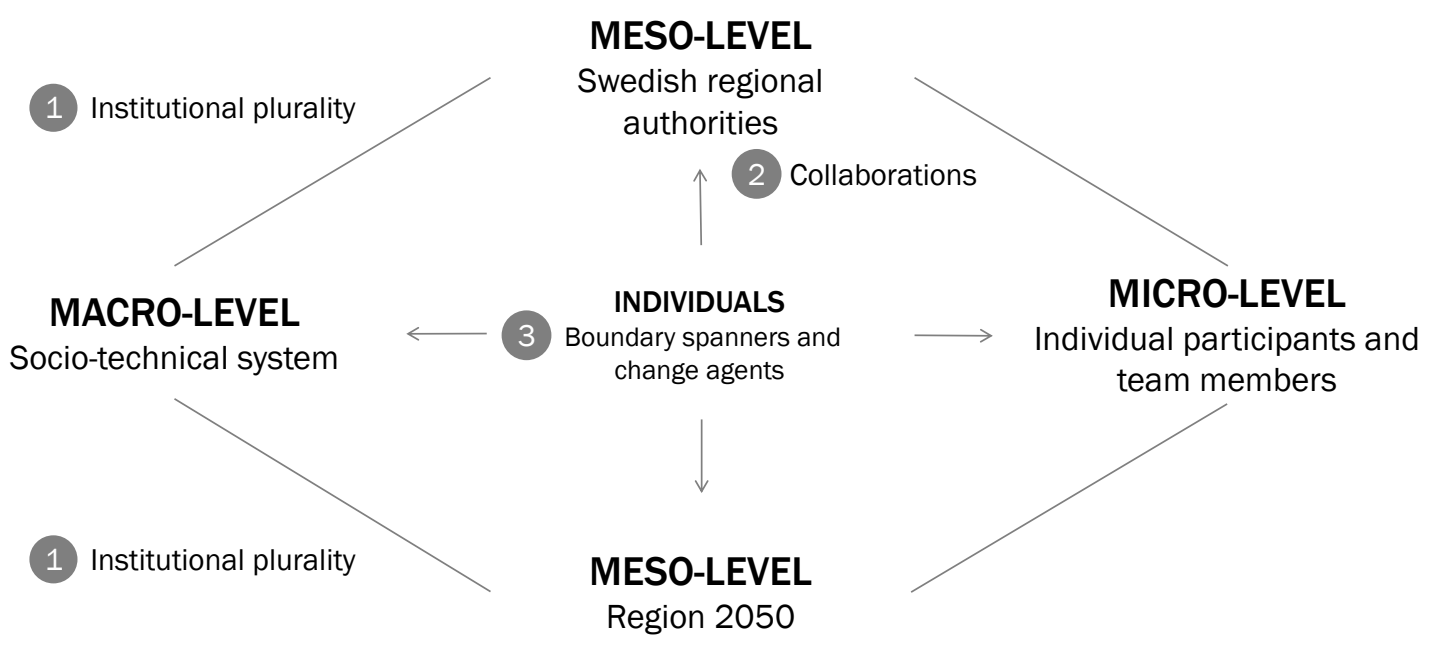

Figure 14: The theoretical framework developed to address the social scales of impact of participatory strategic planning processes (reproduced from Paper IV).

Implementation of the theoretical heuristic in Case III, project Region 2050, revealed misalignment between the institutional logics in the course of the project. Two different logics manifested themselves in Case III - Operational logic and Strategic logic. In the course of data analysis, differences between those two logics along four dimensions were identified (Figure 15). 


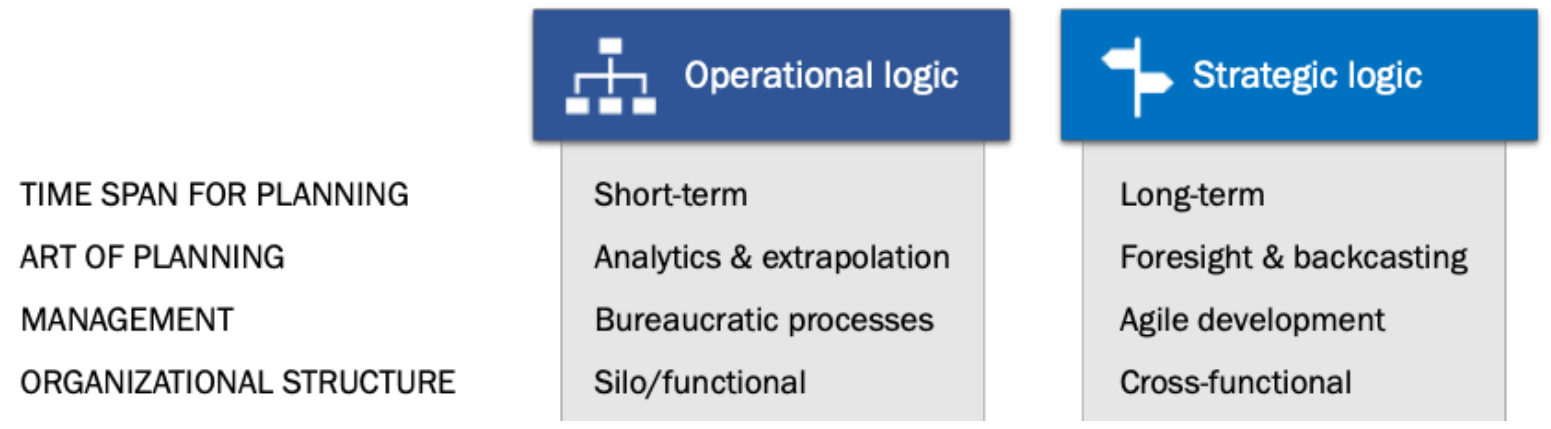

Figure 15: Two different institutional logics identified within Case III: Region 2050 (adapted from Paper IV).

Strategic logic was nested in the methods promoted for long-term planning by Region 2050, while Operational logic was found to be more relevant for the majority of the organisations involved, i.e. Swedish regional authorities. The differences between these two logics posed challenges for the participants in transferring the outcomes of the participatory process (e.g. new methods learned) into their home organisations. See Paper IV for quotes from the interviews that exemplify the role of logic misalignments in Case III.

After logic misalignment was identified as a possible barrier to extending the impact of strategic planning processes beyond the individuals directly involved, the three factors mentioned above were brought to light based on the empirical data from Case III. First, the role of individuals as boundary spanners (i.e. individuals able to connect different institutional logics (Smink et al., 2015)) was identified as an important factor on the micro-level. In the context of Region 2050, the characteristics of boundary-spanning individuals were determined to be: a) networking skills, b) ability to create trust, c) leadership, d) entrepreneurial skills, e) awareness about different logics, f) interpersonal competencies such as empathy and context-related knowledge, g) power and h) in-depth knowledge of methods presented in the scope of Region 2050. Some of those characteristics are also reported in the OCMS and IT literatures (e.g. Hamner et al., 2008; Smink et al., 2015).

Second, as observed in the OCMS literature (Lozano, 2008), this thesis found collaborations among the organisations involved to be a success factor on the meso-level. In the course of Region 2050 (Case III), collaborations emerged among the regional authorities regarding the implementation of new future studies methods in their practice of regional planning. These collaborations were reported by the participants as useful and possibly leading to sharing of experiences from first attempts at incorporating new planning methods in their own environments. It was also concluded that further support of an emerging community of practice among the individuals involved in 
Region 2050 could be beneficial for successful incorporation of these new methods in the practices of regional planning.

Third, institutional plurality (i.e. opportunities for alternative logics to coexist within an organisation (Fuenfschilling and Truffer, 2016)) was observed to be an important factor on meso-level and at the intersection of macro- and meso-levels. Greater institutional plurality within an organisation was suggested as beneficial for a novel logic and associated methods to be adopted by this organisation. However, organisations can choose different strategies for responding to a competing institutional logic, i.e. decoupling, compromising and logic combination (Pache and Santos, 2013). Analysis of such strategies applied by the organisations involved in Region 2050 was beyond the scope of this thesis and requires further investigation.

The findings for Objective 3 regarding the key role of logic mismatches when introducing new methods into the strategic planning process are in line with previous findings (Fuenfschilling and Truffer, 2016; Smink et al., 2015). However, the two logics (operational, strategic) and their characteristics (Figure 15) cannot be generalised from the single case of Region 2050. Further research on implementation of the integrative heuristic developed in this thesis is needed to explore the relevance of this logic in other cases of participatory strategic planning. Similarly, the influence of the three key factors identified in this thesis needs to be examined beyond the single case.

This thesis revealed a promising direction for extending the impact of participatory strategic planning processes beyond the individuals directly involved. Further research is needed to develop mechanisms to be incorporated in such processes as leverage on the factors identified (i.e. role of boundary spanners, collaborations and institutional plurality). For example, activities for developing boundary spanner capacities can be included. Furthermore, on the stage of stakeholder involvement, the possibilities of selecting stakeholder representatives with relevant capacities could be explored. The theoretical heuristic presented in this thesis can be used as a starting point for further elaboration of an approach to study and evaluate social scales of the impact (Hassenforder et al., 2015) of the participatory strategic planning processes. 


\section{Critical reflections}

\subsection{Discussion of limitations}

The quantitative and qualitative methods used in this thesis and the transdisciplinary research (TdR) design applied are associated with a number of limitations related to their objectivity and generalisability, thereby imposing limitations on the findings. The TdR strategy employed to investigate Objectives 1 and 2 involves challenges associated with the need to set a common ground between representatives of different bodies of knowledge, ensure meaningful collaborations and address value conflicts (Wiesmann et al., 2008). In this thesis, mutual learning and reflexivity were promoted to enable efficient collaborations in Case I and Case II. For example, to compensate for possible bias of the researchers involved, a highly reflexive approach was applied during the desktop research phase. The participation in both $\mathrm{mPB}$ projects of researchers from different countries (Ukraine, Sweden and the Netherlands in Case I; Serbia, Ukraine and Sweden in Case II) also helped to maintain a high level of reflexivity and critical perspective during the projects.

Design of TdR projects involves a need to ensure a balance between periods of intense collaboration and periods when disciplinary contributions can be elaborated (Wiesmann et al., 2008). In both Case I and Case II, researchers had the possibility to influence the design of the participatory process as a whole (e.g. define a number, purpose and time of participatory activities and desktop research) and of participatory activities such as co-creation workshops in particular (e.g. aim of activity, modules of mPB to be addressed, timing for different steps). The researchers were also involved in moderation of participatory processes, both the overall process and group work in smaller groups. To ensure efficient moderation, a strategy adopted by the project team was to demand neutrality of the researchers when acting as moderators. In other roles, the researchers were engaged in critical dialogue with other participants.

The moderation strategy and the process design were appreciated by the participants in both cases, leading to creation of a trustful atmosphere during the process. The participants were confident in the quality of process design and constantly participated in the project activities. In addition to these factors, participation in the projects by foreign researchers highly respected in 
both countries, along with their knowledge on local conditions and the respect they demonstrated to the local context, contributed to the positive reception given to the novel planning approaches. It might be more challenging to achieve similar outcomes if only local researchers are involved or if a foreign consultancy with a low level of engagement leads the process. Moreover, as previously observed in TdR studies (e.g. Wiesmann et al., 2008; Lang et al., 2012), the presence of peers able to bridge different disciplinary knowledge areas within a TdR process was found to be important in both cases. The need to train researchers and prepare them for their new roles as moderators and facilitators was partly addressed in capacity-building activities embedded in both cases.

Results produced by $\mathrm{TdR}$ are valid for a particular context and require validation and adaptation before being transferred to a different context (Wiesmann et al., 2008). This limitation is equally relevant for the case study method (Yin, 2011), which was also applied in this thesis. A multiple case study was used for investigation of Objectives 1 and 2. Hence, the results achieved in Case I and Case II regarding e.g. the visions, criteria and pathways (see Table 6 and Table 7 for main outcomes of the mPB projects) are relevant for their societal settings (i.e. the stakeholder representatives involved) and cannot be generalised.

At the same time, analytical generalisation between cases was used in this thesis to formulate Objective 3. Hence, the experience gained in Case I and Case II helped to identify common features of the design of participatory process used for PB-based strategic planning and to formulate a hypothesis on factors influencing the social scales of their impact. In this way, analytical generalisation among the cases provided the possibility to address a novel research question within a different case, Case III.

In contrast to Objectives 1 and 2, which were addressed using the TdR strategy, Objective 3 was investigated using a more conventional research design based on semi-structured interviews and participatory observations. These methods are also associated with limitations, e.g. related to conditions for data collection (Berg, 2001). According to Region 2050 process rules, the researchers involved had to take part in the discussions on an equal basis with other participants. At the same time, to avoid influencing the process, the researchers involved wanted to maintain neutrality regarding the process design and its outcomes in discussions with other participants. This added complexity in the process of observations during co-creation workshops and potentially decreased the quality of critical dialogue among the participants. To ensure good coverage in observation protocols, more than one researcher 
made observations during each of the participatory activities investigated. Later, the collected data were critically discussed by the researchers, who cross-checked and complemented the observations.

As for the generalisability of findings obtained for Objective 3, this is rather limited by the single case study design used. The factors identified as important for social scales of impact (e.g. boundary spanners, collaborations, institutional plurality) and the types of institutional logics found (strategic and operational) are relevant in the context of Region 2050. The theoretical heuristic developed (see Figure 14) can be used as a starting point for investigating factors influencing social scales of impact of other similar participatory processes.

Limitations associated with the data collection and analysis methods used and those identified for the planning framework and participatory modelling approaches for scenario development, selection and analysis developed in this thesis are summarised in Sections 5.1-5.3. For a more detailed description, see Papers I-IV.

\subsection{Theoretical implications}

The work presented in this thesis has a number of theoretical implications. First, the thesis contributes to the PB literature through methodological advances in the participatory backcasting approach by development of the modular PB framework. It also demonstrates the usefulness of connecting the PB literature with the PM literature (e.g. Dreyer and Renn, 2011; Voinov et al., 2016) and the TdR literature (e.g. Scholz, 2000; Lang et al., 2012). Equally important are the contributions on a smaller scale, in terms of the modules and methods used to implement them. For example, distinguishing between external and internal scenarios is shown to be useful for PB processes. This also indicates that the $\mathrm{PB}$ process can incorporate different types of scenarios (see e.g. van Notten (2006) and Amer et al. (2013) for scenario typologies).

Moreover, this thesis contributes to impact analysis of $\mathrm{PB} / \mathrm{mPB}$-based planning processes by identifying a direction for investigation of factors that could influence social scales of the impact. Further connection of findings from OCMS (e.g. Lozano, 2008; Lozano, 2013) and IT (e.g. Powell and DiMaggio, 1991; Thornton and Ocasio, 1999) with those from PB studies would appear to be favourable for impact analysis of $\mathrm{PB}$ processes.

Second, this thesis contributes to the broader future studies literature (e.g. Godet, 2006; Hughes, 2013; Van der Heijden, 2011). The morphological 
method developed in this thesis can be regarded as good practice for scenario development and selection. Furthermore, the multi-organisational or collaborative context of scenario development investigated in this thesis is not adequately covered in the existing future studies literature, which predominantly focuses on scenario planning for a single organisation (e.g. Foster, 1993; Schoemaker and van der Heijden, 1992) or society as a whole (e.g. Meadows and Randers, 2004). Scenario planning with participation of different societal actors is gaining attention among researchers and practitioners seeking to address complex societal issues (Patel et al., 2007; Haatanen et al., 2014). However, this would require adaptation of scenario planning methods to this novel setting and purpose of implementation.

Third, this thesis indicates potential scope for implementation of the $\mathrm{PB} / \mathrm{mPB}$ approach in steering sustainability transitions. Similarly to previous studies (e.g. Späth and Rohracher, 2015), the analysis identified a governance context in the heating and cooling sector as an urban junction context. To steer transitions in such a context, there is a need for mediation and negotiation among a broad range of actors involved, including conventional actors in the system (Jensen et al., 2013). Due to the reliance on consensus building and involvement of a broad range of stakeholders, PB-based approaches can be more suitable for such a context. However, there is a need for further advances in participatory methods in $\mathrm{PB}$ and for elaboration of mechanisms that can increase the impact of such processes on system changes.

Fourth, in line with several recent studies examining use of participatory modelling in a transition context (e.g. Halbe et al., 2015), this thesis demonstrates the usefulness of participatory processes and modelling coinforming each other. Furthermore, this thesis indicates a need for complementing PM with transdisciplinarity principles, in order to e.g. add reflexivity to such processes, make it possible to rethink/change the conventional roles of actors (see e.g. Wittmayer et al. (2016) on the roles of actors in transition contexts) and empower bottom-up initiatives.

Finally, the thesis contributes to the industrial ecology field by addressing the question of how existing systems can be changed towards more sustainable configurations. While industrial ecology scholars have suggested principles for the design of more sustainable systems (e.g. industrial symbiosis, urban metabolism), questions related to the character of changes needed for implementation of these solutions remain understudied in the field (e.g. Lazarevic, 2012; Rotmans and Loorbach, 2009). The mPB framework developed in this thesis can be considered by industrial ecology scholars in 
further research aimed at development of pathways towards sustainable solutions based on IE principles and approaches.

\subsection{Empirical implications}

The research conducted within the scope of this thesis has a number of empirical implications for the use of $\mathrm{mPB}$ to steer sustainability transitions in the heating and cooling sectors of Ukraine and Serbia. For the case cities in Ukraine and Serbia, the work resulted in the development of long-term visions, pathways and short-term action plans for the heating and cooling sectors by 2050. Visions and scenarios developed by local stakeholders in both cities are comparable to European examples and show a high level of ambition and the desire of local actors to bring about sustainability and a better quality of life.

In addition to these tangible outcomes, the work contributed to social learning and capacity development regarding the heating and cooling sector, participatory approaches and long-term planning among the participants involved. At the same time, a need for further advances in engineering, managerial and policy-making capacities in both cities was identified. Furthermore, values, perceptions and beliefs of local stakeholders often prohibit their use of novel and more proactive approaches to planning and policy making, consideration of a broader space of alternatives for heating and cooling, and prioritisation of social and environmental sustainability in decision making. Participatory approaches are helpful in overcoming these challenges, but other supporting mechanisms are also needed. Potentially suitable mechanisms could include: encouragement of collaborations among individuals and organisations willing to initiate and implement changes; involvement and empowerment of actors previously not involved in planning and decision-making (e.g. researchers and citizens); and initiation and institutionalisation of alternative discourses regarding the future of the heating and cooling sector and energy system as a whole.

The energy regimes in Ukraine and Serbia are characterised by numerous social, technological and institutional lock-ins. The incumbent actors in the sector are often not supportive of sustainability transitions in the energy sector and have substantial influence on policy-making processes on different levels. In this situation, initiation of changes in the heating and cooling sector seems to be more feasible on the urban and community level. A recently adopted decentralisation policy in Ukraine (Lankina et al., 2017) is also supportive of such changes. In parallel, broader geopolitical processes are 
contributing to the pressure on the existing socio-technical configuration in the sector. For example, the changed geopolitical situation has recently triggered an increase in the price of natural gas for end-consumers in Ukraine (Saha and Zaslavskiy, 2018). In combination, these factors can create a window of opportunity for changes in the heating and cooling sector in the country, providing the possibility for alternative solutions and alternative planning approaches to be more widely adopted.

In the socio-cultural context of Ukraine and Serbia, the use of quantitative methods and modelling was identified as crucial for the credibility of planning processes and the trustworthiness of their results. However, both these countries also struggle from a low level of quality and reliability of energy data. At the same time, there is a lack of attention to the transparency of assumptions and interpretation of modelling outcomes. To address these challenges, a greater focus on the ethics of modelling and quality of scientific communication is needed. The development of urban data infrastructure in both cities would also be beneficial, so that reliable information on different parts of the heating and cooling system could be systematically collected and made publicly available.

Follow-up activities and iterative adjustment to changing external conditions of the outcomes achieved within PB-based processes are important for steering the heating and cooling sector towards sustainability. The outcomes of $\mathrm{PB}$ processes (e.g. criteria, pathway and action plan) need to be constantly revised in a participatory way. While consensus regarding long-term goals can be easier to achieve, implementation of actions in line with long-term goals can still be challenging and may require conflict management and mediation activities. Directionality and intentionality of actions towards a shared desirable vision can be an important enabler of system transitions.

Finally, collaborations seem to be highly important for changing the situation in the heating and cooling sector towards a more sustainable future. This includes different types of collaboration, e.g. with international researchers and practitioners with greater experience in steering sustainability transitions in the sector, between academic and non-academic stakeholders, and between different types of actors, including government, industry, academia and civil society. Intermediary organisations and boundary spanner individuals can play a crucial role in enabling such collaborations. 


\section{Conclusions}

Strategic planning is a mechanism that can be used for steering developments in the heating and cooling sector towards a more sustainable socio-technical configuration. This thesis addressed the need for advancing strategic planning in this sector to be tailored to accommodate recent changes in its decisionmaking environment (e.g. growing complexity of the sector, closer interrelations with other sectors, an increased number of actors with potentially conflicting interests, a need to balance a set of diverse decisionmaking criteria under highly uncertain future conditions). Through meeting its three research objectives, this thesis contributes with several novel approaches and insights to improving strategic planning in the heating and cooling sector.

With regard to Objective 1, a novel framework for strategic planning in the heating and cooling sector - modular participatory backcasting (mPB), was developed (Paper I). The framework is based on participatory backcasting (PB) and integrates principles of modularity, participatory modelling and transdisciplinarity. When tested in the context of two empirical cases, Case I and Case II, the framework showed potential to be adapted to site-specific factors and project limitations (Paper I). The novel mPB framework allowed for the development of future visions, pathways and short-term action plans for the heating and cooling systems in Case I and Case II. It also enabled engagement of a broader range of stakeholders in the planning processes, considerably prolonged the planning horizon commonly used in both case cities, and prompted an attempt of cross-sectorial planning in both cases.

With regard to Objective 2, a new morphological method for scenario development and selection in the context of mPB-based strategic planning was developed (Paper II). Furthermore, an approach for scenario analysis based on co-informing between quantitative modelling of urban energy systems and participatory processes was implemented (Paper III). Both approaches helped increase the reflexivity and transparency of scenario development, selection and analysis, improved creativity and enabled consideration of a wide range of alternative solutions in participatory planning processes in Case I and Case II.

With regard to Objective 3 , three factors that can be used as leverage points to extend the impact of participatory strategic planning processes beyond the 
individuals directly involved were identified. These were: i) the role of individuals as boundary spanners, ii) institutional plurality and iii) collaborations (Paper IV). In Case III, misalignments between two institutional logics, operational logic and strategic logic, were found to be an important obstacle to organisational changes in line with the outcomes of the participatory process explored.

Overall, the thesis adds to existing evidence on the relevance of urban junction for governance in the heating and cooling sector. It also provides new insights that are important in addressing existing practices of planning in the infrastructure sectors and in developing relevant approaches that can help shift its historically-entrained modes to considerably different modes, e.g. based on the strategic logic identified in Case III.

With the growing complexity of urban systems, the spread of the circular economy and blurred boundaries between sectors and systems, the need for approaches such as $\mathrm{mPB}$ will only increase. In democratic societies, a collaborative/multi-organisational context will continue to be essential for planning and decision making regarding long-term developments in sectors crucial for the quality of life of many people (e.g. energy, mobility, water, food). Further research and innovations in the practice of participatory strategic planning of urban infrastructures could speed up sustainability transitions, while also exploiting the value of local practices and knowledge. 


\section{Further research}

The work reported in this thesis addressed only a few of the important aspects of advancing strategic planning towards sustainability in the heating and cooling sector and other infrastructure sectors based on Participatory backcasting (PB). During the work, a number of directions for further research were uncovered. First, the modular Participatory backcasting (mPB) framework developed in this thesis can be further strengthened in a number of ways. These include improving participatory process design, participatory methods used under the framework and further development of a library of methods to be included in mPB modules. To achieve such developments, experimentation with $\mathrm{mPB}$ in multiple cases is important.

Second, the thesis highlighted challenges with the use of modelling in $\mathrm{PB} / \mathrm{mPB}$-based processes, similar to those observed in previous studies on participatory modelling (e.g. Basco-Carrera et al., 2017; Hämäläinen, 2015; Voinov et al., 2016) and transdisciplinarity (e.g. Lang et al., 2012; Scholz, 2017). Further connecting the findings achieved in those fields with $P B$ studies can be beneficial for advancing the use of different types of modelling within PB-based strategic planning processes.

Third, the thesis identified the existing ambiguity regarding the concept of 'stakeholder' in PB studies, where it is often unclear to what level, individual or organisational, the concept refers. To clearly distinguish individual and organisational stakeholders and address the challenge of representation of organisational stakeholders through individuals, further research needs to be conducted. Insights from OCMS (e.g. Hamner et al., 2008; Lozano, 2008) and IT (e.g. Powell and DiMaggio, 1991; Thornton and Ocasio, 1999) can be helpful in this regard. Application of concepts such as community of practice (Wenger, 1998) can be fruitful in improving understanding of processes and relations formed among participants involved in long-lasting $\mathrm{PB} / \mathrm{mPB}$-based processes. More generally, there is a need to better address the role of agency in PB. This gap is similar to that previously identified in the transition studies field (e.g. Bögel and Upham, 2018; Hassink et al., 2018).

Fourth, the possibility to extend the area of potential suitability of mPB can be explored. For example, the potential of $\mathrm{mPB}$ for steering transitions regarding other infrastructure sectors and societal functions (e.g. mobility, energy, sanitation, food) can be increased through testing and tailoring it in novel 
contexts. Based on the findings in this thesis, experimentation with mPB in other infrastructure sectors characterised by high societal complexity, geographical proximity of technical components, a high risk of technological lock-ins, and a variety of potentially available solutions seems to be a promising research direction.

Fifth, in this thesis work the transferability of PB to the context of postsocialist countries in Eastern Europe, Ukraine and Serbia, was partly addressed. Modularisation was found to be relevant for reducing ambiguity regarding the structure and steps of the planning framework, mPB. Further examination and improvement of transferability of $\mathrm{MPB}$ to different sociocultural contexts can be achieved using insights from the fields of technology/knowledge transfer (e.g. Battistella et al., 2016), policy transfer and learning (e.g. Levi-Faur and Vigoda-Gadot, 2006; Stone, 2004) and translation of management ideas and practices (e.g. Czarniawska and Sevón, 2005).

Sixth, the morphological method for scenario development and selection, can be investigated in multiple cases to address its suitability beyond the heating and cooling sector. Further research regarding improved coverage of system dimensions and inclusion of different types of dimensions (e.g. technical and social) could be particularly interesting. Furthermore, the method can be tested for use in developing external scenarios (possible futures formed by external factors).

Finally, this thesis indicates that current planning practices in the heating and cooling sector must become more supportive of sustainability transitions. A similar observation was made by Malekpour et al. (2015), who explored changes in planning approaches for urban infrastructure since the 1900s. These observations inspired the idea of treating the planning practice as a contributing sub-regime in co-evolutionary processes of socio-technical transitions. 


\section{References}

Allenby, B., 2006. The ontologies of industrial ecology? Progress in Industrial Ecology, An International Journal, 3 (1/2), 28.

Amer, M., Daim, T.U., and Jetter, A., 2013. A review of scenario planning. Futures, 46, 23-40.

Anderson, K.L., Mander, S.L., Bows, A., Shackley, S., Agnolucci, P., and Ekins, P., 2008. The Tyndall decarbonisation scenarios-Part II: Scenarios for a 60\% CO2 reduction in the UK. Energy Policy, 36 (10), 3764-3773.

Andrews, C.J., 2000. Building a Micro Foundation for Industrial Ecology. Journal of Industrial Ecology, 4 (3), 35-51.

Arnstein, S.R., 1969. A Ladder Of Citizen Participation. Journal of the American Planning Association, 35 (4), 216-224.

Ashina, S., Fujino, J., Masui, T., Ehara, T., and Hibino, G., 2012. A roadmap towards a low-carbon society in Japan using backcasting methodology: Feasible pathways for achieving an $80 \%$ reduction in CO2 emissions by 2050. Energy Policy, 41, 584-598.

Avelino, F. and Wittmayer, J.M., 2016. Shifting Power Relations in Sustainability Transitions: A Multi-actor Perspective, 18 (5), 628-649.

Averfalk, H., Ingvarsson, P., Persson, U., Gong, M., and Werner, S., 2017. Large heat pumps in Swedish district heating systems. Renewable and Sustainable Energy Reviews, 79, 1275-1284.

Bach, B., Werling, J., Ommen, T., Münster, M., Morales, J.M., and Elmegaard, B., 2016. Integration of large-scale heat pumps in the district heating systems of Greater Copenhagen. Energy, 107, 321-334.

Baldwin, C. and Clark, K.B., 1997. Managing in an Age of Modularity. Harvard Business Review, 75 (5), 84-93.

Baldwin, C. and Clark, K.B., 2000. Design rules. Volume 1. The power of modularity. MIT Press.

Baldwin, C., Maccormack, A., and Rusnak, J., 2014. Hidden structure: Using network methods to map system architecture. Research Policy, 43 (8), 1381-1397.

Basco-Carrera, L., Warren, A., van Beek, E., Jonoski, A., and Giardino, A., 2017. Collaborative modelling or participatory modelling? A framework for water resources management. Environmental Modelling \& Software, 91, 95-110.

Battistella, C., De Toni, A.F., and Pillon, R., 2016. Inter-organisational technology/knowledge transfer: a framework from critical literature review. Journal of Technology Transfer, 41 (5), 11951234.

Berg, B.L., 2001. Qualitative research methods for the social sciences. 4th ed. California State University, Long Beach: Allyn \& Bacon.

Bögel, P.M. and Upham, P., 2018. Role of psychology in sociotechnical transitions studies: Review in relation to consumption and technology acceptance. Environmental Innovation and Societal Transitions, 28, 122-136.

Bolton, R. and Foxon, T.J., 2015. Infrastructure transformation as a socio-technical process Implications for the governance of energy distribution networks in the UK. Technological Forecasting and Social Change, 90, 538-550.

Boman, M., Bubenko, J., Johannesson, P., and Wangler, B., 1997. Conceptual modelling. Prentice Hall.

Brandt, P., Ernst, A., Gralla, F., Luederitz, C., Lang, D.J., Newig, J., Reinert, F., Abson, D.J., and 
Wehrden, H. Von, 2013. A review of transdisciplinary research in sustainability science. Ecological Economics, 92, 1-15.

Breetz, H.L., 2017. Political-industrial ecology: Integrative, complementary, and critical approaches. Geoforum, 85, 392-395.

Brown, H.S. and Vergragt, P.J., 2008. Bounded socio-technical experiments as agents of systemic change: The case of a zero-energy residential building. Technological Forecasting and Social Change, 75 (1), 107-130.

Bryant, B.P. and Lempert, R.J., 2010. Thinking inside the box: A participatory, computer-assisted approach to scenario discovery. Technological Forecasting and Social Change, 77 (1), 34-49.

Buonomano, A., Calise, F., and Palombo, A., 2018. Solar heating and cooling systems by absorption and adsorption chillers driven by stationary and concentrating photovoltaic/thermal solar collectors: Modelling and simulation. Renewable and Sustainable Energy Reviews, 82, 1874-1908.

Carlsson-Kanyama, A., Dreborg, K.H., Moll, H.C., and Padovan, D., 2008. Participative backcasting: A tool for involving stakeholders in local sustainability planning. Futures, 40 (1), 34-46.

Carmona, G., Varela-Ortega, C., and Bromley, J., 2013. Participatory modelling to support decision making in water management under uncertainty: Two comparative case studies in the Guadiana river basin, Spain. Journal of Environmental Management, 128, 400-412.

Cass, N., Schwanen, T., and Shove, E., 2018. Infrastructures, intersections and societal transformations. Technological Forecasting and Social Change, 137 (February), 160-167.

Czarniawska, B. and Sevón, G., eds., 2005. Global ideas: how ideas, objects and practices travel in the global economy. Vol. 13. Copenhagen Business School Press.

Davies, G.F., Maidment, G.G., and Tozer, R.M., 2016. Using data centres for combined heating and cooling: An investigation for London. Applied Thermal Engineering, 94, 296-304.

Doyle, R. and Davies, A.R., 2013. Towards sustainable household consumption: Exploring a practice oriented, participatory backcasting approach for sustainable home heating practices in Ireland. Journal of Cleaner Production, 48, 260-271.

Dreborg, K.H., 1996. Essence of backcasting. Futures, 28 (9), 813-828.

Dreyer, M. and Renn, O., 2011. Participatory approaches to modelling for improved learning and decision-making in natural resource governance: An editorial. Environmental Policy and Governance, 21 (6), 379-385.

Ebrahimi, K., Jones, G.F., and Fleischer, A.S., 2014. A review of data center cooling technology, operating conditions and the corresponding low-grade waste heat recovery opportunities.

Renewable and Sustainable Energy Reviews, 31, 622-638.

EBRD, 2011. Marker Assesment. Residential Sector in Ukraine: Legal, Regulatory, Institutional, Technical and Financial Considerations. Final report. European Bank for Reconstruction and Development, Worley Parsons. London.

Ehrenfeld, J. and Gertler, N., 1997. Industrial Ecology in Practice: The Evolution of Interdependence at Kalundborg. Journal of Industrial Ecology, 1 (1), 67-79.

Eisentraut, A. and Adam, B., 2014. Heating without global warming. Market Developments and Policy Considerations for Renewable Heat. Featured Insight. Paris.

Elzen, B., Geels, F.W., and Green, K., eds., 2004. System innovation and the transition to sustainability: theory, evidence and policy. Edward Elgar Publishing.

Epstein, J., 2008. Why Model? Cybernetics and Systems, 35 (2-3), 117-128.

European Commission, 2012. Energy roadmap 2050. Luxemburg.

European Commission, 2016. An EU strategy on heating and cooling. Brussels.

Fischer-Kowalski, M. and Rotmans, J., 2009. Conceptualizing, Observing, and Influencing Social Ecological Transitions. Ecology and Society, 14 (2), 1-19. 
Foster, M.J., 1993. Scenario planning for small businesses. Long Range Planning, 26 (1), 123-129.

Frantzeskaki, N. and Loorbach, D., 2010. Towards governing infrasystem transitions. Reinforcing lock-in or facilitating change? Technological Forecasting and Social Change, 77 (8), 1292-1301.

Frantzeskaki, N., Loorbach, D., and Meadowcroft, J., 2012. Governing societal transitions to sustainability. Journal of Sustainable Development, 15, 19-36.

Frederiksen, S. and Werner, S., 2013. District heating and cooling. Lund: Lund: Studentlitteratur.

Fuenfschilling, L. and Truffer, B., 2014. The structuration of socio-technical regimes - Conceptual foundations from institutional theory. Research Policy, 43 (4), 772-791.

Fuenfschilling, L. and Truffer, B., 2016. The interplay of institutions, actors and technologies in socio-technical systems - An analysis of transformations in the Australian urban water sector. Technological Forecasting and Social Change, 103, 298-312.

Fuso Nerini, F., Tomei, J., To, L.S., Bisaga, I., Parikh, P., Black, M., Borrion, A., Spataru, C., Castán Broto, V., Anandarajah, G., Milligan, B., and Mulugetta, Y., 2018. Mapping synergies and trade-offs between energy and the Sustainable Development Goals. Nature Energy, 3 (1), 10-15.

Gabillet, P., 2015. Energy supply and urban planning projects: Analysing tensions around district heating provision in a French eco-district. Energy Policy, 78, 189-197.

Geels, F.W., 2004. From sectoral systems of innovation to socio-technical systems: Insights about dynamics and change from sociology and institutional theory. Research Policy, 33 (6-7), 897-920.

Giurco, D., Cohen, B., Langham, E., and Warnken, M., 2011. Backcasting energy futures using industrial ecology. Technological Forecasting and Social Change, 78 (5), 797-818.

Godet, M., 2006. Creating Futures: Scenarios Planning as a Strategic Management Tool. Paris: Economica Ltd.

Godet, M. and Durance, P., 2011. Strategic Foresight: for corporate and regional development. Paris: DUNOD-UNESCO-Fondation Prospective et Innovation.

Green, K. and Randles, S., 2006. Industrial ecology and spaces of innovation. Edward Elgar Pub.

Greenwood, R. and Suddaby, R., 2006. Institutional Entrepreneurship In Mature Fields: The Big Five Accounting Firms. Academy of Management Journal, 49 (1), 27-48.

Grin, J., Rotmans, J., and Schot, J.W., 2010. Transitions to sustainable development: new directions in the study of long term transformative change. Routledge.

Grinchenko, V., Kordas, O., Pereverza, K., Quist, J., Nikiforovich, E., Korostyleva, G., Pasichnyi, O., and Voloschuk, V., 2013. Deliverable 4 . 6 - Workshop on interactive backcasting. Report for EUFP7-Project ERAIHM (FP7-INCO-2010-6/266587). Kyiv.

Grødeland, A.B. and Aasland, A., 2011. Civil Society in Post-Communist Europe: Perceptions and Use of Contacts. Journal of Civil Society, 7 (2), 129-156.

Haatanen, A., den Herder, M., Leskinen, P., Lindner, M., Kurttila, M., and Salminen, O., 2014. Stakeholder engagement in scenario development process - Bioenergy production and biodiversity conservation in eastern Finland. Journal of Environmental Management, 135, 45-53.

Halbe, J., 2016. Governance of Transformations towards Sustainable Water, Food and Energy Supply Systems Facilitating Sustainability Innovations through Multi-Level Learning Processes. University of Osnabrück.

Halbe, J., Knüppe, K., Knieper, C., and Pahl-Wostl, C., 2018. Towards an integrated flood management approach to address trade-offs between ecosystem services: Insights from the Dutch and German Rhine, Hungarian Tisza, and Chinese Yangtze basins. Journal of Hydrology, 559, 984-994.

Halbe, J., Reusser, D.E., Holtz, G., Haasnoot, M., Stosius, A., Avenhaus, W., and Kwakkel, J.H., 2015. Lessons for model use in transition research: A survey and comparison with other research areas. Environmental Innovation and Societal Transitions, 15, 194-210. 
Hämäläinen, R.P., 2015. Behavioural issues in environmental modelling - The missing perspective. Environmental Modelling and Software, 73, 244-253.

Hamner, D., Hall, A.C., Timmons, J.C., Boeltzig, H., and Fesko, S., 2008. Agents of change in the disability field: bridge-builders who make a difference, 21 (2), 161-173.

Haslauer, E., Biberacher, M., and Blaschke, T., 2012. GIS-based Backcasting: An innovative method for parameterisation of sustainable spatial planning and resource management. Futures, 44 (4), 292-302.

Hassenforder, E., Smajgl, A., and Ward, J., 2015. Towards understanding participatory processes: Framework, application and results. Journal of Environmental Management, 157, 84-95.

Hassink, J., Grin, J., and Hulsink, W., 2018. Enriching the multi-level perspective by better understanding agency and challenges associated with interactions across system boundaries. The case of care farming in the Netherlands: Multifunctional agriculture meets health care. Journal of Rural Studies, 57 (December 2017), 186-196.

Hawkey, D., Webb, J., and Winskel, M., 2013. Organisation and governance of urban energy systems: District heating and cooling in the UK. Journal of Cleaner Production, 50, 22-31.

Heaps CG. Long-range energy alternatives planning (LEAP) system (software version 2014.0.1.24). Stockholm Environment Institute; 2012. available at: www.energycommunity.org.

Hedegaard, K., Mathiesen, B.V., Lund, H., and Heiselberg, P., 2012. Wind power integration using individual heat pumps - Analysis of different heat storage options. Energy, 47 (1), 284-293.

Van der Heijden, K., 2011. Scenarios: the art of strategic conversation. John Wiley \& Sons.

Heiskanen, E., Kivisaari, S., Lovio, R., and Mickwitz, P., 2009. Designed to travel? Transition management encounters environmental and innovation policy histories in Finland. Policy Sciences, 42 (4), 409-427.

Hentschel, M., Ketter, W., and Collins, J., 2018. Renewable energy cooperatives: Facilitating the energy transition at the Port of Rotterdam. Energy Policy, 121, 61-69.

Herbst, A., Toro, F.A., Reitze, F., and Jochem, E., 2012. Introduction to Energy Systems Modelling. Swiss Journal of Economics and Statistics (SJES), 148 (II), 111-135.

Hodson, M., Marvin, S., Robinson, B., and Swilling, M., 2012. Reshaping Urban Infrastructure: Material Flow Analysis and Transitions Analysis in an Urban Context. Journal of Industrial Ecology, 16 (6), 789-800.

Hoffman, K.C. and Wood, D.O., 1976. Energy System Modeling and Forecasting. Annual Review of Energy, 1, 423-453.

Holmberg, J. and Robert, K.-H., 2000. Backcasting - a framework for strategic planning. International Journal of Sustainable Development \& World Ecology, 7 (4), 291-308.

Holtz, G., Alkemade, F., De Haan, F., Kohler, J., Trutnevyte, E., Luthe, T., Halbe, J., Papachristos, G., Chappin, E., Kwakkel, J., and Ruutu, S., 2015. Prospects of modelling societal transitions:

Position paper of an emerging community. Environmental Innovation and Societal Transitions, 17, 41-58.

Hughes, N., 2013. Towards improving the relevance of scenarios for public policy questions: A proposed methodological framework for policy relevant low carbon scenarios. Technological Forecasting and Social Change, 80 (4), 687-698.

Hughes, T.P., 1983. Networks of Power. Electrification in Western Society, 1880-1930. 2nd ed. The John Hopkins University Press.

IEA, 2016. World Energy Outlook. Paris Cedex.

IEA, 2018. The Future of Cooling. Opportunities for energy-efficient air conditioning.

Jansen, L., 2003. The challenge of sustainable development. Journal of Cleaner Production, 11 (3), 231-245. 
Jensen, J.S., Lauridsen, E.H., Fratini, C.F., and Hoffmann, B., 2015. Harbour Bathing and the Urban Transition of Water in Copenhagen: Junctions, Mediators, and Urban Navigations. Environment and Planning A, 47 (3), 554-570.

Jouhara, H. and Yang, J., 2018. Energy efficient HVAC systems. Energy and Buildings, 179, 83-85.

Kahneman, D., Slovic, P., and Tversky, A., 1982. Judgment under uncertainty: heuristics and biases. Cambridge University Press.

Kanter, D.R., Schwoob, M.-H., Baethgen, W.E., Bervejillo, J.E., Carriquiry, M., Dobermann, A., Ferraro, B., Lanfranco, B., Mondelli, M., Penengo, C., Saldias, R., Silva, M.E., and de Lima, J.M.S., 2016. Translating the Sustainable Development Goals into action: A participatory backcasting approach for developing national agricultural transformation pathways. Global Food Security, 10, 71-79.

Keirstead, J., Jennings, M., and Sivakumar, A., 2012. A review of urban energy system models: Approaches, challenges and opportunities. Renewable and Sustainable Energy Reviews, 16 (6), 3847-3866.

Kemp, R. and Loorbach, D., 2006. Transition management: a reflexive governance approach. In: J.P. Voss, D. Bauknecht, and R. Kemp, eds. Reflexive governance for sustainable development. Cheltenham, UK and Northampton, MA, USA: Edward Elgar, 103-131.

Kennedy, C., Baker, L., Dhakal, S., and Ramaswami, A., 2012. Sustainable Urban Systems: An Integrated Approach. Journal of Industrial Ecology, 16 (6), 775-779.

Kennedy, C., Cuddihy, J., and Engel-Yan, J., 2007. The Changing Metabolism of Cities. Journal of Industrial Ecology, 11 (2), 43-59.

Kirby, A., 2019. Transdisciplinarity and sustainability science: A response to Sakao and BrambilaMacias in the context of sustainable cities research. Journal of Cleaner Production, 210, 238-245.

Kishita, Y., Mclellan, B.C., Giurco, D., Aoki, K., Yoshizawa, G., and Handoh, I.C., 2017.

Technological Forecasting \& Social Change Designing backcasting scenarios for resilient energy futures. Technological Forecasting \& Social Change.

Kivimaa, P., 2014. Government-affiliated intermediary organisations as actors in system-level transitions. Research Policy, 43 (8), 1370-1380.

Klerkx, L., Aarts, N., and Leeuwis, C., 2010. Adaptive management in agricultural innovation systems: The interactions between innovation networks and their environment. Agricultural Systems, 103 (6), 390-400.

Köhler, J., Turnheim, B., and Hodson, M., 2018. Low carbon transitions pathways in mobility: Applying the MLP in a combined case study and simulation bridging analysis of passenger transport in the Netherlands. Technological Forecasting and Social Change.

Kok, K., van Vliet, M., Bärlund, I., Dubel, A., and Sendzimir, J., 2011. Combining participative backcasting and exploratory scenario development: Experiences from the SCENES project. Technological Forecasting and Social Change, 78 (5), 835-851.

Kucharski, J.B. and Unesaki, H., 2018. An institutional analysis of the Japanese energy transition. Environmental Innovation and Societal Transitions, (July).

Kuckartz, U., 2014. Qualitative text analysis: A guide to methods, practice and using software. Sage.

Kvale, R., 2008. Doing interviews. Sage.

Kylili, A. and Fokaides, P.A., 2015. European smart cities: The role of zero energy buildings. Sustainable Cities and Society, 15, 86-95.

Lang, D.J., Wiek, A., Bergmann, M., Moll, P., Swilling, M., and Thomas, C.J., 2012.

Transdisciplinary research in sustainability science: practice, principles, and challenges.

Langlois, R.N., 2002. Modularity in technology and organization. Journal of Economic Behavior and Organization, 49 (1), 19-37. 
Lankina, T., Gordon, C., and Slava, S., 2017. Regional Development in Ukraine: Priority Actions in Terms of Decentralization.

Lazarevic, D.A., 2012. Life Cycle Thinking and Waste Policy: Between Science and Society. KTH Royal Institute of Technology.

Leal-Arcas, R., Lesniewska, F., and Proedrou, F., 2018. Prosumers as New Energy Actors. In: Africa-EU Renewable Energy Research and Innovation Symposium. Springer, Cham, 139-151.

Leonzio, G., 2018. An innovative trigeneration system using biogas as renewable energy. Chinese Journal of Chemical Engineering, 26 (5), 1179-1191.

Levi-Faur, D. and Vigoda-Gadot, E., 2006. New public policy, new policy transfers: Some characteristics of a new order in the making. International Journal of Public Administration, 29 (4-6), 247-262.

Loorbach, D., Frantzeskaki, N., and Avelino, F., 2017. Sustainability Transitions Research: Transforming Science and Practice for Societal Change. Annual Review of Environment and Resources, 42, 599-626.

Loorbach, D., Frantzeskaki, N., and Thissen, W., 2010. Introduction to the special section: Infrastructures and transitions. Technological Forecasting and Social Change, 77 (8), 1195-1202.

Lovins, A.B., 1976. Energy Strategy: The Road Not Taken? Foreign Affairs, 55 (1), 65-96.

Lovins, A.B., 1979. Soft Energy Paths: Toward a Durable Peace. New York: Harper \& Row.

Lozano, R., 2008. Developing collaborative and sustainable organisations. Journal of Cleaner Production, 16, 499-509.

Lozano, R., 2013. A holistic perspective on corporate sustainability drivers. Corporate Social Responsibility and Environmental Management, 22 (1), 32-44.

Lozano, R., 2014. Creativity and organizational learning as means to foster sustainability. Sustainable Development, 22 (3), 205-216.

Lund, H., 2018. Renewable heating strategies and their consequences for storage and grid infrastructures comparing a smart grid to a smart energy systems approach. Energy, 151, 94-102.

Lund, H., Werner, S., Wiltshire, R., Svendsen, S., Thorsen, J.E., Hvelplund, F., and Mathiesen, B.V., 2014. 4th Generation District Heating (4GDH). Energy, 68, 1-11.

Lundh, M. and Dalenbäck, J.-O., 2008. Swedish solar heated residential area with seasonal storage in rock: Initial evaluation. Renewable Energy, 33 (4), 703-711.

Malekpour, S., Brown, R.R., and de Haan, F.J., 2015. Strategic planning of urban infrastructure for environmental sustainability: Understanding the past to intervene for the future. Cities, 46, 67-75.

Malinauskaite, J., Jouhara, H., Czajczyńska, D., Stanchev, P., Katsou, E., Rostkowski, P., Thorne, R.J., Colón, J., Ponsá, S., Al-Mansour, F., Anguilano, L., Krzyżyńska, R., López, I.C.,

A.Vlasopoulos, and Spencer, N., 2017. Municipal solid waste management and waste-to-energy in the context of a circular economy and energy recycling in Europe. Energy, 141, 2013-2044.

Mander, S.L., Bows, A., Anderson, K.L., Shackley, S., Agnolucci, P., and Ekins, P., 2008. The Tyndall decarbonisation scenarios-Part I: Development of a backcasting methodology with stakeholder participation. Energy Policy, 36 (10), 3754-3763.

Markard, J. and Truffer, B., 2006. Innovation processes in large technical systems: Market liberalization as a driver for radical change? Research Policy, 35 (5), 609-625.

Maskrey, S.A., Mount, N.J., Thorne, C.R., and Dryden, I., 2016. Participatory modelling for stakeholder involvement in the development of flood risk management intervention options. Environmental Modelling and Software, 82, 275-294.

Matovic, D., 2011. Biochar as a viable carbon sequestration option: Global and Canadian perspective. Energy, 36 (4), 2011-2016.

McDonough, J.R., Law, R., Reay, D.A., and Zivkovic, V., 2018. Intensified carbon capture using 
adsorption: Heat transfer challenges and potential solutions. Thermal Science and Engineering Progress, 8, 17-30.

McDowall, W. and Geels, F.W., 2017. Ten challenges for computer models in transitions research: Commentary on Holtz et al. Environmental Innovation and Societal Transitions, 22, 41-49.

McKechnie, L.E.F., 2008. Participant Observation. In: L.M. Given, ed. The SAGE Encyclopedia of Qualitative Research Methods. Thousand Oaks: SAGE Publications, Inc, 599.

Meadows, D. and Randers, J., 2004. The Limits to Growth: The 30-year Update. London: Routledge.

Meadows, D.H., 2008. Thinking in systems: A primer. Chelsea Green Publishing.

Mendoza, G.A. and Prabhu, R., 2005. Combining participatory modeling and multi-criteria analysis for community-based forest management. Forest Ecology and Management, 207 (1-2 SPEC. ISS.), 145-156.

Miller, L. and Carriveau, R., 2018. A review of energy storage financing-Learning from and partnering with the renewable energy industry. Journal of Energy Storage, 19, 311-319.

Mills, A., Durepos, G., and Wiebe, E., 2010. Encyclopedia of Case Study Research. Thousand Oaks California: SAGE Publications, Inc.

Ministry of the Fuels and Energy of Ukraine, M., 2012. Renewal of the Ukrainian energy strategy by 2030. Kyiv.

Moallemi, E.A. and Malekpour, S., 2018. A participatory exploratory modelling approach for longterm planning in energy transitions. Energy Research and Social Science, 35 (October 2017), 205216.

Mulder, K.F., 2007. Innovation for sustainable development: From environmental design to transition management. Sustainability Science, 2 (2), 253-263.

Nakao, M., Nabeshima, M., Kobayashi, Y., and Ishinada, M., 2018. Thermal grid system and its field test in multiple buildings with individual heating and cooling facility. Energy Procedia, 149, 112121.

Neuvonen, A. and Ache, P., 2017. Metropolitan vision making - using backcasting as a strategic learning process to shape metropolitan futures. Futures.

Nijhuis, M., Gibescu, M., and Cobben, J.F.G., 2015. Assessment of the impacts of the renewable energy and ICT driven energy transition on distribution networks. Renewable and Sustainable Energy Reviews, 52, 1003-1014.

Nilsson, A., Lazarevic, D., Brandt, N., and Kordas, O., 2018. Household responsiveness to residential demand response strategies: Results and policy implications from a Swedish field study. Energy Policy, 122, 273-286.

van Notten, P., 2006. Scenario development: A typology of approaches. Schooling for tomorrow think scenarios, rethink education, OECD Education \& Skills, (2005), 66-92.

OECD/IEA, 2006. Ukraine. Energy Policy Review. Paris Cedex.

Pache, A.-C. and Santos, F., 2013. Inside the Hybrid Organization: Selective Coupling as a Response to Competing Institutional Logics. Academy of Management Journal, 56 (4), 972-1001.

Pandis Iveroth, S., 2014. Industrial ecology for sustainable urban development - The case of Hammarby Sjöstad.

Pasichnyi, O., Wallin, J., Levihn, F., Shahrokni, H., and Kordas, O., 2019. Energy performance certificates - New opportunities for data-enabled urban energy policy instruments? Energy Policy, 127, 486-499.

Patel, M., Kok, K., and Rothman, D.S., 2007. Participatory scenario construction in land use analysis: An insight into the experiences created by stakeholder involvement in the Northern Mediterranean. Land Use Policy, 24 (3), 546-561. 
Patuzzi, F., Prando, D., Vakalis, S., Maria, A., Chiaramonti, D., Tirler, W., Mimmo, T., Gasparella, A., and Baratieri, M., 2016. Small-scale biomass gasification CHP systems: Comparative performance assessment and monitoring experiences in South Tyrol (Italy). Energy, 112, 285-293.

Perez, N., Riederer, P., and Inard, C., 2018. Development of a multiobjective optimization procedure dedicated to the design of district energy concept. Energy and Buildings, 178, 11-25.

Persson, U., Möller, B., and Werner, S., 2014. Heat Roadmap Europe: Identifying strategic heat synergy regions. Energy Policy, 74, 663-681.

Phdungsilp, A., 2011. Futures studies' backcasting method used for strategic sustainable city planning. Futures, 43 (7), 707-714.

Pina, E.A., Lozano, M.A., and Serra, L.M., 2018. Thermoeconomic cost allocation in simple trigeneration systems including thermal energy storage. Energy, 153, 170-184.

Powell, W.W. and DiMaggio, P.J., eds., 1991. The new institutionalism in organizational analysis. Chicago: The University of Chicago Press.

Purcell, M., 2006. Urban Democracy and the Local Trap, 43 (11), 1921-1941.

Quist, J., 2007. Backcasting for a sustainable future: the impact after 10 years. Delft University of Technology.

Quist, J., 2013. Backcasting and Scenarios for Sustainable TechnologyDevelopment. In: J. Kauffman and K.-M. Lee, eds. Handbook of Sustainable Engineering.

Quist, J., Thissen, W., and Vergragt, P.J., 2011. The impact and spin-off of participatory backcasting: From vision to niche. Technological Forecasting and Social Change, 78 (5), 883-897.

Quist, J. and Vergragt, P., 2006. Past and future of backcasting: The shift to stakeholder participation and a proposal for a methodological framework. Futures, 38 (9), 1027-1045.

Reed, M.S., Kenter, J., Bonn, A., Broad, K., Burt, T.P., Fazey, I.R., Fraser, E.D.G., Hubacek, K., Nainggolan, D., Quinn, C.H., Stringer, L.C., and Ravera, F., 2013. Participatory scenario development for environmental management: a methodological framework illustrated with experience from the UK uplands. Journal of environmental management, 128, 345-62.

Reglab. 2017. Region 2050. [ONLINE] Available at: http://www.reglab.se/. [Accessed 15 February 2019].

Reglab. 2018. Region 2050. [ONLINE] Available at: http://www.reglab.se/. [Accessed 15 February 2019].

Ritchey, T., 2011. Wicked Problems - Social Messes. Media, 19 (1974), 106.

Ritchey, T., 2018. General morphological analysis as a basic scientific modelling method. Technological Forecasting and Social Change, 126, 81-91.

Robinson, J., 2003. Future subjunctive: backcasting as social learning. Futures, 35 (8), 839-856.

Robinson, J., Burch, S., Talwar, S., O'Shea, M., and Walsh, M., 2011. Envisioning sustainability: Recent progress in the use of participatory backcasting approaches for sustainability research. Technological Forecasting and Social Change, 78 (5), 756-768.

Robinson, J.B., 1982. Energy backcasting A proposed method of policy analysis. Energy Policy, 10 (4), 337-344.

Romanchenko, D., Kensby, J., Odenberger, M., and Johnsson, F., 2018. Thermal energy storage in district heating: Centralised storage vs. storage in thermal inertia of buildings. Energy Conversion and Management, 162, 26-38.

Rotmans, J. and Loorbach, D., 2009. Complexity and transition management. Journal of Industrial Ecology, 13 (2), 184-196.

Saha, S. and Zaslavskiy, I., 2018. Advancing Natural Gas Reform in Ukraine.

Salomón, M., Savola, T., Martin, A., Fogelholm, C., and Fransson, T., 2011. Small-scale biomass 
CHP plants in Sweden and Finland. Renewable and Sustainable Energy Reviews, 15 (9), 44514465.

Schoemaker, P.J.H. and van der Heijden, C.A.J.M., 1992. Integrating scenarios into strategic planning at Royal Dutch/Shell. Planning Review, 20 (3), 41-46.

Scholz, R.W., 2000. Mutual Learning as a Basic Principle of Transdisciplinarity. In:

Transdisciplinarity: Joint Problem-solving among Science, Technology and Society. Proceedings of the International Transdisciplinarity 2000 Conference. Haffman, Zürich, 13-17.

Scholz, R.W., 2017. The normative dimension in Transdisciplinarity, Transition Management, and Transformation Sciences: New roles of science and universities in sustainable transitioning. Sustainability, 9 (991), 1-31.

Sisto, R., van Vliet, M., and Prosperi, M., 2016. Puzzling stakeholder views for long-term planning in the bio-economy: A back-casting application. Futures, 76, 42-54.

Smink, M., Negro, S.O., Niesten, E., and Hekkert, M.P., 2015. How mismatching institutional logics hinder niche-regime interaction and how boundary spanners intervene. Technological Forecasting and Social Change, 100, 225-237.

Smith, A., Stirling, A., and Berkhout, F., 2005. The governance of sustainable socio-technical transitions. Research Policy, 34 (10), 1491-1510.

Soria-Lara, J.A. and Banister, D., 2017. Participatory visioning in transport backcasting studies: Methodological lessons from Andalusia (Spain). Journal of Transport Geography, 58, 113-126.

Späth, P. and Rohracher, H., 2015. Conflicting strategies towards sustainable heating at an urban junction of heat infrastructure and building standards. Energy Policy, 78, 273-280.

Stone, D., 2004. Transfer agents and global networks in the 'transnationalization' of policy. Journal of European Public Policy, 11 (3), 545-566.

Störmer, E., Truffer, B., Dominguez, D., Gujer, W., Herlyn, A., Hiessl, H., Kastenholz, H., Klinke, A., Markard, J., Maurer, M., and Ruef, A., 2009. The exploratory analysis of trade-offs in strategic planning: Lessons from Regional Infrastructure Foresight. Technological Forecasting and Social Change, 76 (9), 1150-1162.

Svenfelt, Å., Engström, R., and Svane, Ö., 2011. Decreasing energy use in buildings by $50 \%$ by 2050 - A backcasting study using stakeholder groups. Technological Forecasting and Social Change, 78 (5), 785-796.

Tešić, M., Kiss, F., and Zavargo, Z., 2011. Renewable energy policy in the Republic of Serbia. Renewable and Sustainable Energy Reviews, 15 (1), 752-758.

The City of Niš, 2014. Sustainable Energy Action Plan. Niš: City Council of Niš.

Thornton, P. and Ocasio, W., 1999. Institutional Logics and the Historical Contingency of Power in Organizations: Executive Succession in the Higher Education Publishing Industry, 1958-1990.

Truffer, B., Störmer, E., Maurer, M., and Ruef, A., 2010. Local strategic planning processes and sustainability transitions in infrastructure sectors. Environmental Policy and Governance, 20 (4), 258-269.

Truffer, B., Voß, J.P., and Konrad, K., 2008. Mapping expectations for system transformations. Lessons from Sustainability Foresight in German utility sectors. Technological Forecasting and Social Change, 75 (9), 1360-1372.

United Nations, 2015. Transforming our world: the 2030 Agenda for Sustainable Development. United Nations: General Assembly.

Urban, F., Benders, R.M.J., and Moll, H.C., 2007. Modelling energy systems for developing countries. Energy Policy, 35 (6), 3473-3482.

Vernay, A.L., Mulder, K.F., Kamp, L.M., and De Bruijn, H., 2013. Exploring the socio-technical dynamics of systems integration-the case of sewage gas for transport in Stockholm, Sweden. Journal of Cleaner Production, 44, 190-199. 
Vinca, A., Rottoli, M., Marangoni, G., and Tavoni, M., 2018. The role of carbon capture and storage electricity in attaining 1.5 and $2{ }^{\circ} \mathrm{C}$. International Journal of Greenhouse Gas Control, 78, 148-159.

Voinov, A. and Gaddis, E.J.B., 2008. Lessons for successful participatory watershed modeling: A perspective from modeling practitioners. Ecological Modelling, 216 (2), 197-207.

Voinov, A., Kolagani, N., McCall, M.K., Glynn, P.D., Kragt, M.E., Ostermann, F.O., Pierce, S.A., and Ramu, P., 2016. Modelling with stakeholders - Next generation. Environmental Modelling and Software, 77, 196-220.

Van der Voorn, T., Pahl-Wostl, C., and Quist, J., 2012. Combining backcasting and adaptive management for climate adaptation in coastal regions: A methodology and a South African case study. Futures, 44 (4), 346-364.

Voß, J.P., Smith, A., and Grin, J., 2009. Designing long-term policy: rethinking transition management. Policy sciences, 42 (4), 275-302.

Vujic, G., Stanisavljevic, N., Batinic, B., Jurakic, Z., and Ubavin, D., 2017. Barriers for implementation of "waste to energy" in developing and transition countries: a case study of Serbia. Journal of Material Cycles and Waste Management, 19 (1), 55-69.

Wack, P., 1985. Scenarios: uncharted waters ahead. Harvard Business Review, 73-89.

Wamsler, C., 2017. Stakeholder involvement in strategic adaptation planning: Transdisciplinarity and co-production at stake? Environmental Science and Policy, 75, 148-157.

Wenger, E., 1998. Communities of practice: learning, meaning, and identity. Cambridge University Press.

Werner, S., 2017. International review of district heating and cooling. Energy, 137, 617-631.

Wiesmann, U., Biber-Klemm, S., Grossenbacher-Mansuy, W., Hirsch Hadorn, G., Hoffmann-Riem, H., Joye, D., Pohl, C., and Zemp, E., 2008. Enhancing Transdisciplinary Research. In: G. Hirsch Hadorn, H. Hoffmann-Riem, S. Biber-Klemm, W. Grossenbacher-Mansuy, D. Joye, C. Pohl, U. Wiesmann, and E. Zemp, eds. Handbook of Transdisciplinary Research. Bern: Dordrecht: Springer, 433-441.

Williams, A., Kennedy, S., Philipp, F., and Whiteman, G., 2017. Systems thinking: A review of sustainability management research. Journal of Cleaner Production, 148, 866-881.

Williams, P., 2002. The Competent Boundary Spanner. Public Administration, 80 (1), 103-124.

Wilson, C., 2013. Semi-structured interviews. In: Interview Techniques for UX Practitioners. A UserCentered Design Method. Morgan Kaufmann, 24-41.

Wittmayer, J.M., Avelino, F., van Steenbergen, F., and Loorbach, D., 2016. Actor roles in transition: Insights from sociological perspectives. Environmental Innovation and Societal Transitions.

Wolczuk, K., 2016. Managing the flows of gas and rules: Ukraine between the EU and Russia Managing the flows of gas and rules: Ukraine between. Eurasian Geography and Economics, 57 (1), 96-116.

Wolman, A., 1965. The Metabolism of Cities. Scientific American, 213 (3), 178-193.

Wright, G., Bradfield, R., and Cairns, G., 2013. Does the intuitive logics method - and its recent enhancements - produce 'effective' scenarios? Technological Forecasting and Social Change, 80 (4), 631-642.

Wu, W. and Skye, H.M., 2018. Net-zero nation: HVAC and PV systems for residential net-zero energy buildings across the United States. Energy Conversion and Management, 177, 605-628.

Yegorov, I., 2009. Post-Soviet science: Difficulties in the transformation of the R\&D systems in Russia and Ukraine. Research Policy, 38 (4), 600-609.

Yin, R.K., 2011. Applications of case study research. SAGE Publications, Inc.

Zivkovic, M., Ivezic, D., Madzarevic, A., Manic, D., Kordas, O., Pereverza, K., Pasichnyi, O., Vukasinovic, V., Boskovic, G., and Rakic, N., 2015. Towards sustainable heating and cooling in Nis, 
Serbia. Report for Tempus project SDTrain (in Serbian). Belgrade.

Zwicky, F., 1948. The morphological method of analysis and construction. In: Courant Anniversary Volume. 461-470.

Zwicky, F., 1969. Discovery, Invention, Research Through the Morphological Approach. 

ISBN 978-91-7873-125-1

TRITA-ABE-DLT-198

www.kth.se 